Florida International University

FIU Digital Commons

6-5-2019

\title{
How State Capacity Matters: A Study of the Cooptation and Coercion of Religious Organizations in Southeast Asia and Beyond
}

Adam Howe

ahowe015@fiu.edu

Follow this and additional works at: https://digitalcommons.fiu.edu/etd

Part of the Comparative Politics Commons

\section{Recommended Citation}

Howe, Adam, "How State Capacity Matters: A Study of the Cooptation and Coercion of Religious Organizations in Southeast Asia and Beyond" (2019). FIU Electronic Theses and Dissertations. 4267. https://digitalcommons.fiu.edu/etd/4267

This work is brought to you for free and open access by the University Graduate School at FIU Digital Commons. It has been accepted for inclusion in FIU Electronic Theses and Dissertations by an authorized administrator of FIU Digital Commons. For more information, please contact dcc@fiu.edu. 


\section{FLORIDA INTERNATIONAL UNIVERSITY}

Miami, Florida

HOW STATE CAPACITY MATTERS: A STUDY OF THE COOPTATION AND COERCION OF RELIGIOUS ORGANIZATIONS IN SOUTHEAST ASIA AND BEYOND

A dissertation submitted in partial fulfillment of the

requirements for the degree of

DOCTOR OF PHILOSOPHY

in

POLITICAL SCIENCE

by

Adam E. Howe 
To: Dean John F. Stack, Jr.

Steven J. Green School of International and Public Affairs

This dissertation, written by Adam E. Howe, and entitled How State Capacity Matters: A Study of the Cooptation and Coercion of Religious Organizations in Southeast Asia and Beyond, having been approved in respect to style and intellectual content, is referred to you for judgment.

We have read this dissertation and recommend that it be approved.

$\begin{array}{r}\text { John F. Clark } \\ \hline \text { Tatiana Kostadinova } \\ \hline \text { Steven Vose } \\ \hline \text { Barry S. Levitt, Major Professor }\end{array}$

Date of Defense: June 5, 2019

The dissertation of Adam E. Howe is approved.

Dean John F. Stack, Jr. Steven J. Green School of International and Public Affairs

Andrés G. Gil Vice President for Research and Economic Development and Dean of the University Graduate School

Florida International University, 2019 
(C) Copyright 2019 by Adam E. Howe

All Rights Reserved 


\section{DEDICATION}

I dedicate this dissertation to my wife, Friday. This project would not have been possible without her love, patience, and tireless support. 


\section{ACKNOWLEDGMENTS}

I wish to thank the members of my committee for their dedication, feedback, and encouragement. My major professor, Dr. Barry Levitt, believed in this dissertation from its inception and graciously guided me through multiple draft versions of this project. Dr. John Clark provided valuable feedback on case study chapters, while Dr. Tatiana Kostadinova helped me work through important methodological questions. Finally, Dr. Steven Vose brought a unique perspective to this dissertation, resulting in a more thorough examination of religious organizations in Southeast Asia.

I would also like to acknowledge the Morris and Anita Broad Fellowship, Stanford University's Hoover Institution Library and Archives, and the Florida International University Graduate School's Dissertation Year Fellowship for generous research support. 
ABSTRACT OF THE DISSERTATION

HOW STATE CAPACITY MATTERS:

A STUDY OF THE COOPTATION AND COERCION

OF RELIGIOUS ORGANIZATIONS IN

SOUTHEAST ASIA AND BEYOND

by

Adam E. Howe

Florida International University 2019

Miami, Florida

Professor Barry S. Levitt, Major Professor

This dissertation examines the complex relationship between state capacity, authoritarian regimes and religious organizations in Southeast Asia and beyond. Through an interdisciplinary synthesis of secondary literatures in Comparative Politics, Sociology, and Religious Studies, complemented by archival research conducted at Stanford University's Hoover Institution, this dissertation argues that relative state capacity endowment shapes the strategies that authoritarian regime elites employ against domestic religious organizations as a means of ensuring regime survival. Through typological theory-building and a comparative case-study methodology I argue that state capacity, imagined in terms of both bureaucratic/administrative and coercive components, influences whether authoritarian regime elites decide to pursue policies of cooptation 
(bribery, patronage, and political appointments) or coercion (incarceration, threats, violence) vis-à-vis religious organizations. Comparative case-study analysis of the relationship between authoritarian regimes and religious organizations in Burma, Thailand, Malaysia, Cambodia, Laos, Vietnam, the Democratic Republic of the Congo, Poland, and Nicaragua reveals clear variations in regime elite strategies across time and space. Specifically, my findings demonstrate that authoritarian regime elites in states with strong bureaucratic/administrative capacity and strong coercive capacity have relied on cooptation as their preferred strategy for containing threats posed by religious organizations, while regime elites in states with weak bureaucratic/administrative capacity and strong coercive capacity have instead tended to employ violence against these groups. Finally, regime elites in states with weak bureaucratic/administrative capacity and weak coercive capacity have cycled, unsuccessfully, between policies of cooptation and coercion in the hopes of containing powerful domestic religious organizations. The comparative analysis in this dissertation provides a nuanced explanation for how authoritarian regime elites leverage state resources to counter threats posed by symbolically-powerful religious groups and contributes a new mid-range theory of state-society relations with implications for authoritarian regimes far beyond the region. 


\section{TABLE OF CONTENTS}

CHAPTER

PAGE

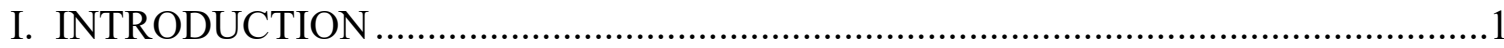

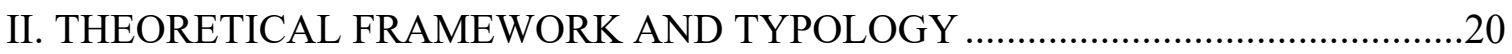

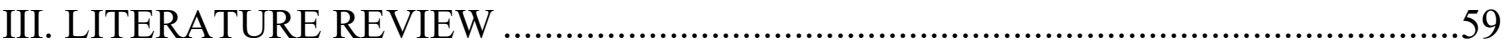

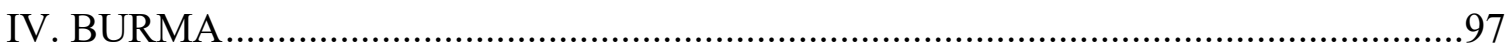

V. THAILAND AND MALAYSIA ............................................. 131

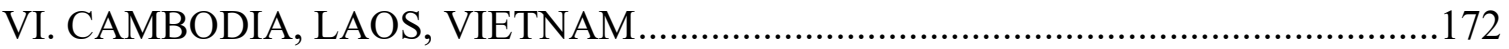

VII. DEMOCRATIC REPUBLIC OF THE CONGO, POLAND, NICARAGUA ........211

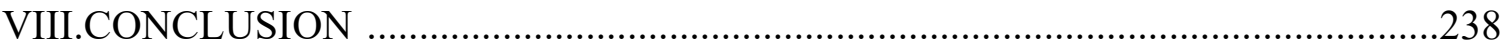

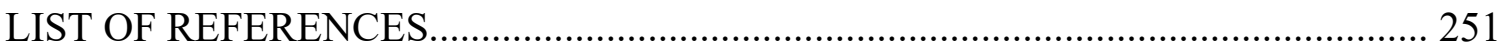

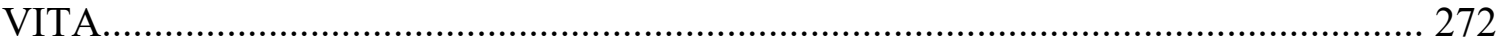




\section{LIST OF TABLES}

TABLE

PAGE

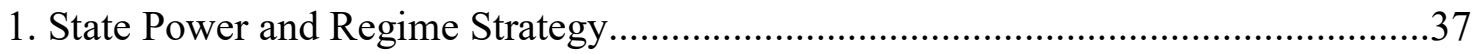

2. Authoritarianism in Southeast Asia......................................................................

3. Religious Organizations in Southeast Asia...........................................................48

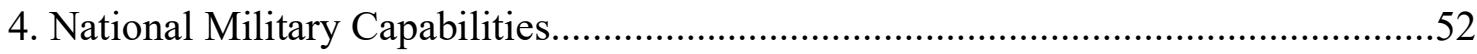

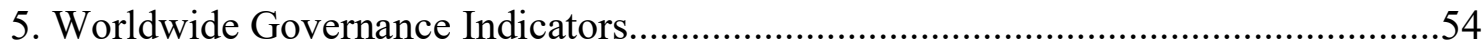

6. Government Regulation of Religion...............................................................56

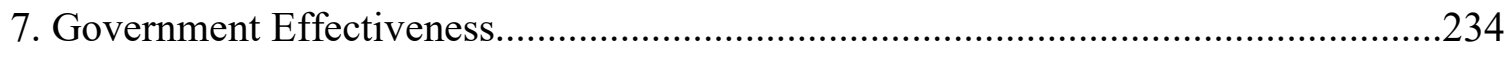

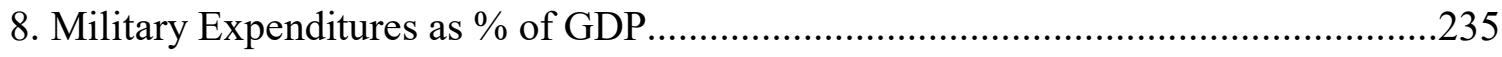

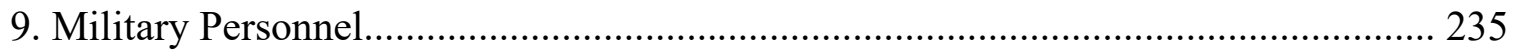

10. State Power in Southeast Asia and Beyond.............................................................241

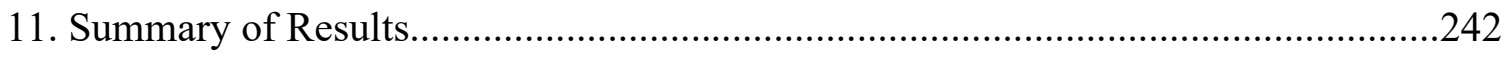




\section{LIST OF FIGURES}

FIGURE

PAGE

1. State Capacity, Regime Capacity, and Religious Organization Strategy..................44

2. National Military Personnel in 100,000's (Southeast Asia) ....................................49

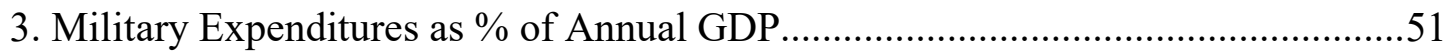

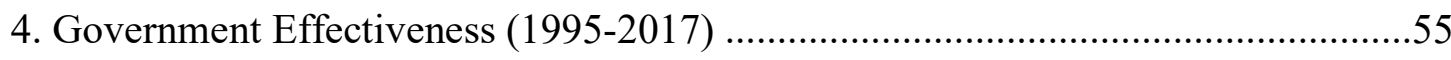




\section{INTRODUCTION}

This dissertation examines how state capacity shapes the relationship between authoritarian regimes and religious organizations across Southeast Asia. While much of the recent political science literature has focused extensively on authoritarian institutions (Gandhi and Przeworski 2007; Boix and Svolik 2013), this research proposes that state capacity has a powerful influence on the behavior of regimes and religious organizations alike. It begins with the assumption that regimes inherit their states, and thus vary in their ability to exercise power over society. It then argues that authoritarian regimes will attempt to co-opt, or alternatively, coerce religious organizations in order to remain in power. Whether these regimes pursue strategies of coercion or cooptation is largely a function of their state capacity.

While civil society is certainly not as robust under authoritarian regimes as in consolidated democracies, very few states in history have proven capable of fully controlling their respective societies. In much of Southeast Asia, religious organizations exist as a visible, albeit constrained, alternative locus of social power. While not fully independent from the state's coercive and administrative apparatuses, religious organizations do carve out spheres of autonomy. Even in contexts where a specific religious organization is co-opted by the state, it can retain some degree of control over its affairs through selected strategies.

The complex relationship between the state and religious organizations in S.E. Asia cannot be properly understood in a snapshot. Instead, this research project takes a historical case-study approach, tracing the evolution of both the state and select religious 
organizations in the region's post-independence era. In this context, each state under consideration shares some important similarities which make them suitable for comparison. Except for Thailand, all states in the region are former colonies and have had the difficult task of building modern state bureaucracies with limited resources. Additionally, all the states have faced significant challenges to their sovereignty from both internal and external actors. Finally, there are no cases examined here that are consolidated democracies, as all have endured long periods of authoritarian rule. These similarities are not intended to gloss over the region's differences. Though not insensitive to the region's diversity, these commonalities allow me to test important hypotheses about the relationship between state capacity, regime power, and religious organizations.

This research will focus specifically on the following states: Burma, Malaysia, Thailand, Cambodia, Laos, and Vietnam. Each of the preceding is classified as authoritarian by Freedom House (2018), though their respective scores within this category vary over time. Burma stands apart as the country with the longest history of authoritarian rule, while Thailand has alternated between periods of democracy and military rule. Malaysia has liberalized over the past decade, but it still falls well short of several important democratic benchmarks, including freedom of the press (Freedom House, 2018). Cambodia, Laos, and Vietnam share the legacy of the Vietnamese War and the Marxist-inspired regimes which assumed power at the end of the conflict. All three states continue to liberalize slowly under the watchful gaze of nominally communist regimes. 
In terms of civil society, this research attends mainly to hierarchical Buddhist national religious organizations, except for Vietnam and Malaysia, where appropriate attention will be devoted to Catholic and Muslim religious organizations respectively. The focus on Buddhist organizations is done for practical reasons, as all countries in this analysis, except Malaysia, are majority Buddhist. The religious groups in this context are also organized in a comparably hierarchical fashion. While some attention will be devoted to the role of lay religious organizations, most of the research will focus on groups with a highly visible and centralized leadership structure. These similarities give me the leverage to analyze strategic interactions more efficiently.

\section{Theory and Method}

The significance of this research lies in its comparative and interdisciplinary nature. Through a synthesis of multiple literatures from political science, sociology, and religious studies this dissertation engages in a novel theory-building exercise. This project contributes to a growing literature which emphasizes the importance of the state as an object for political analysis. It also fills an important gap in the literature as the interactive relationship between state capacity, regimes, and religious organizations has not been adequately researched. Finally, it takes a comparative approach to the study of Southeast Asia, an understudied region in the discipline. ${ }^{1}$

This dissertation analyzes three analytically distinct entities: the state, authoritarian regime elites, and religious organizations. As such, my theoretical approach

\footnotetext{
${ }^{1}$ See Alagappa (1995)
} 
to understanding each concept should be examined in some detail. The idea of the state, though problematized in a variety of ways, is couched here in the Neo-Weberian tradition, which imagines the state as a conceptually and analytically distinct entity. As an important actor its own right, the state features different varieties of power. On the one hand, it possesses bureaucratic/administrative power, or the capacity to effectively penetrate society through government institutions. It also features coercive power, or the capacity to compel citizens into compliance with official policies. ${ }^{2}$ While each state differs with respect to reserves of bureaucratic/administrative and coercive power, it is also important to note that state capacity is not typically built in the short-term but is the product of a much longer historical process. In the Southeast Asian context, differences in systems of precolonial and colonial governance, explains, in part, the uneven development of modern states across the region.

In this dissertation, regimes are conceptualized as the individuals and institutions that administer the state. As authoritarian regimes lack the legitimacy conferred from free and fair democratic elections, their survival typically depends on policies of patronage and repression. With respect to civil society and other non-state actors, authoritarian regimes recognize the presence of any organization outside of their control as a potential challenge to their rule. In response to threats from non-state groups, I argue that authoritarian regime elites may either co-opt members through financial patronage,

\footnotetext{
2 These definitions are adopted from Michael Mann's seminal work on the state. See Mann (1984)
} 
political appointments or a combination of both. Alternately, governing elites may also engage in violence as a means of curtailing the organizational strength of these groups. Coercive policies aimed at religious organizations take the shape of threats, incarceration and physical violence.

In this respect, this dissertation puts forth the argument that authoritarian regimes, and the leaders that run them, face a series of policy decisions when confronted with real or perceived threats from religious organizations. These groups typically feature reserves of social power conferred from their traditional status in society. Thus, violent crackdowns against these groups may provoke popular uprisings against a regime which may result in further confrontations and international isolation. In this respect, I argue that authoritarian regimes in Southeast Asia prefer to co-opt important religious groups and avoid violent confrontation. ${ }^{3}$ However, as not all regimes have pursued this course of action, this variation requires greater explanation.

The reason behind these decisions, I argue, is not due solely to differences in regime ideology across cases. As this dissertation illustrates, Marxist regimes in Cambodia, Vietnam, and Laos with a shared commitment to minimize the influence of religion in their respective states, have approached religious organizations differently across time and space. Similarly, variation in the treatment of religion is not due solely to the individual psychological characteristics of individual leaders. Ostensibly pious leaders have resorted to crackdowns against members of their own religion, while

\footnotetext{
${ }^{3}$ The Khmer Rouge's strategy toward Buddhism in Cambodia (1975-1979) represents an extreme version of coercion, as their genocidal war against religion was unprecedented in the Southeast Asian context.
} 
avowedly secular leaders have lavishly patronized religion. Instead, I argue that the explanation for the variation in the treatment of organized religion by authoritarian regimes in Southeast Asia and beyond is due to corresponding variations in state capacity.

Methodologically, this dissertation has identified cases through a most-similarsystems design, whereby the number of variables is reduced to better identify patterns of causality. Thus, cases are grouped according to geographic similarities, a shared legacy of authoritarian rule, and the presence of socially powerful religious organizations. Similarly, the timeframe for analysis is restricted to the post-war era, though important historical context is provided in each chapter. This dissertation alsi engages in typological theory building and testing. This exercise is not intended to generate a strictly deterministic account of the relationship between state capacity, authoritarianism and religious organizations, but strives instead to identify broader causal patterns.

\section{Case Studies}

In this dissertation the complex relationship between the state, authoritarian regimes, and religious organizations are examined across six Southeast Asian cases: Burma, Thailand, Malaysia, Vietnam, Cambodia, and Laos. In the final case study chapter, I expand my analysis to consider countries outside the region, namely the Democratic Republic of the Congo, Poland, and Nicaragua. What follows is a brief introduction to these cases.

In Burma, the military regime's governance (1962-2015) has been overlaid with appeals for national unity based upon the Buddhist tradition. Similarly, the regime has 
understood the importance of co-opting the country's Buddhist leadership (sangha). As Taylor (2009) illustrates, "The purpose of the organization of the sangha body was clearly to strengthen the authority of the state over the monkhood. This was one of the goals of the state throughout Myanmar's history" (Taylor 2009, 360). Numerous attempts on the part of the regime to control Buddhist organizations have varied in terms of success. In 1990 and 2000, the regime decreed that all independent Buddhist monk organizations were banned, and politicized monks could be tried under a military tribunal (ICG 2001, 17).

As the effective control of the sangha was certainly prioritized by the regime, its capacity to do so has been circumscribed by the historical legacy of the state itself. The regime's limited ability to control the sangha is directly linked to the state's historical inability to exercise power over civil society at the village level, an area where monks are highly organized. David Steinberg (1999) writes, "The quintessential example of civil society ubiquitous throughout Burmese history have been religious organizations at the local level" (Steinberg 1999, 5).

The military regime's inability to control religious organizations locally can also be traced back to its unwillingness to engage in the mass mobilization of its citizenry (Slater, 2010 25-26). During the period of post-colonial state formation, the military emerged as the only viable institution in Burma. The state's infrastructural power, namely its civilian bureaucratic apparatus, never developed at the same pace as the military. Mary Callahan (2003) writes, "Uneven development across sites of power within the national state led to military aggrandizement of resources, responsibilities, and powers in 
traditionally nonmilitary realms" (Callahan 2003, 18). Furthermore, Burma never developed a party system or ideology that represented anything more than a front for the regime's own political and economic interests. This highly exclusionary approach to rule may have insulated the regime from internal fractionalization, but it left most of its citizens with little stake in the regime itself. In the absence of a mobilizing ideology, citizens in Burma have maintained connections with traditional, local authority structures to the detriment of the regime itself.

\section{Malaysia}

In Malaysia, religious identity, historically tied to ethnicity and nationalism, contributed to the rise of political parties designed to represent a variety of ethnoreligious groups. During the early part of the $20^{\text {th }}$ century, the British intended to weaken the power of the Muslim Malay majority via ethnic Chinese and Indian minorities, through the creation of a "Malay Union". This power-sharing arrangement was supposed to transfer power from traditional Sultans to minority ethnic leaders. Instead, the policy generated insecurity among the majority ethnic group, empowered Malay nationalist sentiments, and led to the formation of United Malays National Organization (Miller 2004, 2). In the post-independence era, the UMNO and the Barisan National (an alliance of 11 smaller regional parties), have dominated the political landscape. Its principal rival, the Islamic Party of Malaysia (PAS), is an Islamist party dedicated to according Islam a central role in Malaysian politics. Throughout the 1970's, during a period of Islamic revivalism in Malaysia, the UMNO embraced Islamist rhetoric as a means of curtailing the growing influence of the PAS. As a result, the latter turned to more radical politics to 
distance itself from the UMNO (Ibid, 5). Under Prime Minister Mahathir's rule, the UMNO engaged in symbolic gestures intended to appease more religious voters. In terms of policy, the state has actively sponsored religion through the establishment of Islamic Research Centers, Universities, and banking centers.

The UMNO has effectively co-opted religious authority in Malaysia through the state bureaucracy. With organizations expressly designed to incorporate religious authorities into the state structure, the Malaysian state has been able to promote its brand of moderate Islam and marginalize more radical elements. The key location where cooptation has been most effective is in the institutionalized religious bureaucracy. Prominent Islamic scholars in Malaysia have helped to enforce government policies, thus increasing the state's resource of symbolic power. The most prominent example of this being Prime Minister Mahathir's invitation to Islamic revivalist leader Anwar Ibrahim to join the administration in 1993 (Ibid, 5). Though Anwar was later dismissed, the case illustrates the UMNO's capacity to co-opt Malaysia's important religious leaders. In the meantime, the Malaysian state has worked diligently to avoid alienating minority groups.

\section{Thailand}

Traditionally, politics in Thailand have been officially sanctioned by the royal family. Since 1932, Thailand has experienced 11 successful military coups, and 7 attempted coups. Despite chronic episodes of political instability, Thailand has relatively high state capacity compared to its neighbors in the region. Its ethno-religious homogeneity as well as freedom from colonial conquest may help to explain how Thailand's state-building project was relatively successful. Due to the relative strength of 
the state, successful regime cooptation of the sangha (Buddhist monkhood) has been so effective, that smaller faith-based groups have arisen to challenge the cozy relationship between the monkhood and the state.

Theravada Buddhism has played a central role in modern Thai politics. Despite frequent changes in political leadership, the sangha has developed an unbreakable bond with the royal family, guaranteeing its own popular legitimacy. While the sangha in Thailand is diverse in terms of its practice, it has not escaped state control. In fact, the Thai sangha has assisted the state through the creation of a legitimating ideology that defends orthodoxy and authoritarianism (McCargo 2004, 168). In the southern part of Thailand, some monks have even taken up arms to protect their state from an ethnic Malay insurgency. The Thai sangha's close relationship with the state has contributed to high-profile corruption cases, revealing the former's penchant for luxurious living and black-market profits. Consequently, the sangha's popular legitimacy has been compromised over the past three decades.

\section{Laos}

The modern political history of Laos is inextricably linked to the Vietnam War and its aftermath. During the early independence period, the Kingdom of Laos and its Royal Lao Army fought a series of wars against the North Vietnamese and Soviet backed Pathet Lao communist forces. Initially, many members of the sangha in Laos supported the communist guerillas as they had promised to cleanse the country of corruption. Simultaneously, the Kingdom of Laos had a difficult time asserting their role as protectors of Buddhist tradition, as long as they were willing to maintain a strong alliance 
with the West. In the following years, the Royal Lao government had been weakened by Vietnamese incursions and the guerilla tactics of the Pathet Lao insurgency. In 1975, the Pathet Lao was able to seize power and has led the country ever since.

Unlike their neighbors in Cambodia, the Pathet Lao formed the People's Democratic Republic of Laos through a coalition government with what remained of the Royal Lao government. However, this arrangement proved to be short-lived as the PDR deliberately weakened the Royal Lao political forces from within (Holt 2009, 130). By 1975, the PDR had effectively seized control of the government, and had issued a demand for all foreign entities to leave the country. Despite their Marxist ideological commitments, the PDR did not officially attempt to abolish or suppress Buddhism. Rather, they sought to co-opt Buddhist leaders and encourage a new form of Buddhism compatible with Marxist ideology. While this was the official position, the PDR was far from united on this matter. There are several documented cases where local military commanders cleared monasteries of religious texts and art work (ibid, 139). During the early years of PDR rule, there was a marked increase in the number of refugee monks, accompanied by a decrease in vocations, which seems to suggest that the PDR was not as tolerant of religion as is popularly assumed.

Under the PDR, attempts to control the sangha and corresponding religious practice have largely failed. In one sense, the regime seems to fear alienating Buddhists, who constitute roughly 60 percent of the population. This is particularly important given the PDR's protracted conflict with upland non-Buddhist minority groups. In place of official repression, the regime's attempts to cleanse Buddhism of its more "superstitious" 
elements have not been effective. While Laotians are somewhat wary of propagating religion in the public space, the regime has officially sanctioned certain religious festivals.

\section{Cambodia}

The treatment of religion in Cambodia has been subject to extreme variation, making it different from any other state in Southeast Asia. In the immediate postindependence era, the monarchy attempted to forge a synthesis between Western socialism and traditional Buddhist practice. The "Buddhist Socialist" project undertaken by Prince Sihanouk during the 1950 's, accompanied by state monetary support for the sangha, resulted in an increase in monastic vocations and the official dedication of new temples. However, by the late 1960 's, communist forces, supported by the North Vietnamese began to exert greater influence in Cambodian politics. A military coup in 1970 further polarized the sangha, as the latter began to define themselves in terms of their support or opposition to communism. Under the leadership of General Lon Nol, and his "Khmer Republic", high-ranking monks were asked to serve in official capacities, some of which involved spying on their fellow monks (Harris 2016, 16). During the Cambodian civil war, the Khmer Rouge made use of sympathetic monks to recruit peasants to their cause. By 1974, the Khmer Republic, despite extensive support from the United States, was unable to sustain attacks from the North Vietnamese and the Khmer Rouge insurgency. In April 1975, Pol Pot, the leader of the Khmer Rouge, evacuated the capital and took power. 
Under Pol Pot's reign, the Khmer Rouge waged a war on nearly every element of Cambodian society, targeting religion for extermination. From 1975-1979, Buddhist monks were routinely executed under suspicion of subverting the revolutionary project. Monasteries were seized by the regime and turned into army barracks or detention and torture centers. Monks were also subjected to forced labor, and in some cases forced marriage. By the time the Vietnamese had defeated the Khmer Rouge, it is estimated that 25,168 monks were killed, and 1,968 pagodas were destroyed (Ibid, 128). While Pol Pot and the Khmer Rouge exhibited strong ideological opposition to organized religion, it is important to note that many Buddhist monks died in the same manner as civilians, through starvation and exhaustion. Yet, there is ample evidence to suggest that monks were perceived by the regime as a relic of the past that had to be destroyed in the spirit of the revolution.

After the fall of the Khmer Rouge, and Vietnam's invasion, Pol Pot and his loyalists continued to fight a protracted guerilla war against the newly formed People's Republic of Kampuchea. During this period (1979-1989), the sangha was still subject to repression, though nowhere on par with the violence undertaken by the Khmer Rouge. The state allowed Buddhist monks to practice their religion, though under tight regulations. Monks were highly encouraged to preach on the ideological compatibilities between Marxism and Buddhism. Furthermore, "unofficial monks", or monks deemed illegitimate by the regime, were frequently disrobed during the 1980's, and many were sent to fortify the border with Thailand. 
After the fall of the Soviet Union, material support for the communist regime waned, and the constitutional monarchy was eventually restored. Under the new State of Cambodia (SOC), Buddhism was implemented as the official state religion. However, the sangha remains weak and highly fragmented, and has thus far been unable to overcome the legacy of communist repression. Regime violence against Cambodian monks has been common, particularly during the lead-up to elections.

\section{Vietnam}

Vietnam's post-colonial history is characterized by two distinct periods. In the South, during the U.S. sponsored Diem regime (1955-1963), a system of Catholic patronage isolated both the Buddhist majority and religious minority groups. Diem's persecution of these groups was inextricably linked to his government's anti-communist policies. During the 1950's and early 1960's, culminating in the Sect Crisis, Diem and his supporters believed, with some justification that pro-communist forces in the North were drawing sympathizers from the Buddhist and religious minority sect communities. As Diem's persecution of these groups intensified, so did their participation in the opposition. As tensions rose in south Vietnam, Diem accepted thousands of Catholic refugees from the North in the hopes of constructing a bulwark against his opponents. After the U.S. withdrew support, and Diem was removed in a military coup, successive U.S.-sponsored governments were incapable of slowing the Communist advance from the North, or the growing number of Vietcong in the South. As the Vietnam war progressed, large numbers of refugees, both Buddhist and Catholic, fled the country. 
In the post-war era, unified Vietnam has established control over religious organizations through the Department of Religion, which reports directly to the Communist party. For Buddhism two sangha councils have been established (The Sangha Patronage Council and the Dharma Executive Council). There are also regional councils set up to oversee the practice of Buddhism on the provincial level. ${ }^{4}$ While the 2003 Constitution provides for freedom of religion, religious groups are still required to register with the government. In practice, the Vietnamese government has limited the number of individuals eligible to enter either the priesthood or the sangha. 2004 legislation prohibits the forced conversion of individuals, a law that has been expanded to encompass proselytizing and is targeted at Evangelical Christians (U.S. Department of State 2017). Vietnam's organizational control over religion remains firm, as the regime continues to enforce annual limits on the number of individuals who can enter religious life. Religious practice outside of officially sanctioned organizations remains strongly curtailed.

\section{Poland}

The historically close relationship between Polish society and the Catholic Church predates the modern era. Following the devastation wrought by World War II and Soviet occupation, the Church survived as the most important non-state institution in the country. During the post-war era, the Soviet-sponsored Polish government sought to exercise control over the Catholic Church in the same manner that it did in other Eastern

\footnotetext{
${ }^{4}$ For more on the supervision of religion in Vietnam see Abuza, Zachary (2001).
} 
European satellite states. While successive authoritarian regimes did persecute select high-ranking members of the Church, it was incapable of driving a wedge between Polish citizens and organized Catholicism. Instead, the Polish Church gradually adopted a proactive role in society, acting as a key interlocuter between disgruntled citizens and the Communist regime. Since the fall of the Berlin Wall, the Catholic Church remains a highly influential political actor in the country, in part by shaping the agendas of socially conservative political movements during the last decade.

\section{Democratic Republic of Congo}

The people of the Democratic Republic of the Congo belong in large numbers to one of the Christian denominations: The Catholic Church and various Protestant churches. After a particularly brutal colonial occupation, the advent of the modern Congolese state was scarred by deep political divisions. After a series of conflicts, Mobutu See Seko took power and administered the state through a politics of personalism (1965-1997). His regime's relationship with the Catholic Church was marked by alternating periods of repression and accommodation. As the Church had the resources and experience required to administer the educational and social services sectors, Mobutu was unable to build a bureaucratic/administrative state apparatus strong enough to assume these responsibilities. While control over the Catholic Church was outside of Mobutu's grasp, his regime did exercise significant influence over the numerically smaller and denominationally divided Protestant churches. Mobutu unified these churches under one organizational umbrella, and thus limited their political influence in the Congo. 
Following a coup that removed Mobutu from power, the DR Congo endured a decade of civil war, and authoritarian governance under the Kabila family. During this era, violence against Catholic political dissidents has been commonplace, culminating in highly-visible public government crackdowns during the past two electoral cycles. While the Catholic Church remains influential in the DR Congo, its political and social power is also challenged by the growth of Evangelical churches across the country.

\section{Nicaragua}

Much of the twentieth century in Nicaragua was initially dominated by the Somoza family, who maintained their rule through control of the export economy and a favorable political relationship with the United States. During the Somoza era, the domestic Catholic Church remained largely aloof from the Nicaraguan masses, preferring to remain outside of the realm of politics completely. Yet, the Catholic hierarchy's implicit support for the political status quo culminated in an ideological split in the Church during the 1960's. In concert with the rise of a socially-engaged Catholicism in other parts of Latin America, some members of the Nicaraguan Catholic Church adopted the tenets of Liberation Theology, which emphasized a "preferential option for the poor" (Bradstock 1987, 9).

During the 1970's, Catholic priests and nuns constructed Christian Base Communities, which eventually formed a leftist base of resistance to the Somoza regime. With the victory of the Sandinistas, many Catholic clergy and lay persons eagerly participated in government. For its part, the FSLN did not engage in large scale persecution against the Church, though it did occasionally clash with members of the 
conservative clerical establishment. At the end of a decade of civil war in the 1980's, the FSLN exited power and made way for a series of center-right governments. Since 2008, Nicaragua has been subjected to the creeping authoritarianism of the Daniel Ortega regime. Over the past two years there has been a clear deterioration in relations between the Church and government as anti-regime protests have prominently featured large numbers of Catholic clergy.

\section{Dissertation Outline}

This dissertation is organized as follows: the first chapter presents the theoretical framework and research methodology. Here, attention is devoted to the development of my typology and measurement of important variables. The second chapter is a literature review. Specifically, it analyzes how other scholars have thought about the state, authoritarian regime strategy, and the place of organized religion in non-democratic contexts. Chapter 3 investigates how successive authoritarian regimes in Burma, operating in a weak bureaucratic and coercive state have attempted to counter threats posed by Theravada Buddhism. Chapter 4 examines how regime elites in the stronger states of Thailand and Malaysia have approached political threats emanating from Buddhism and Islam respectively. Chapter 5 focuses on the ostensibly Marxist regimes of Cambodia, Laos, and Vietnam, demonstrating important variations in the treatment of organized religion across cases. Chapter 6 expands the analysis beyond Southeast Asia to consider cases of the Democratic Republic of the Congo, Poland, and Nicaragua. Here, the organizational strength of the international Catholic Church is juxtaposed against 
regimes which have struggled to contain its influence on domestic politics. The final chapter synthesizes conclusions and identifies important avenues for future research. 


\section{II: THEORETICAL FRAMEWORK AND TYPOLOGY}

This dissertation examines the complex relationship between state capacity, authoritarian regimes, and religious organizations in Southeast Asia and beyond, arguing that the relative strength of the state shapes the types of strategies available to authoritarian regimes vis-à-vis religious organizations within their borders. In analyzing the complex relationship between states, regimes, and religion, this chapter will proceed as follows. First, I will briefly outline several theoretical propositions about the state, which in turn structure its relationship with regimes and religious organizations. ${ }^{5}$ The second section introduces my typological theory and puts forth corresponding hypotheses, with a clear emphasis placed on testability and generalizability. The next section engages in a thorough discussion of qualitative methods, addressing this dissertations' research design and case selection. The chapter concludes with a focus on data and measurement, presenting indicators for different dimensions of state capacity, regimes, and religion for the six Southeast Asian country cases.

As much as has been written on state capacity and its myriad effects on a host of political phenomena, such as the likelihood of civil war (DeRouen and Sobek 2004; Theis 2010), or regional variance in rates of economic development (Hamm, King and Stuckler 2012; Knutsen 2013), this dissertation makes explicit what is often assumed in other studies, namely, that state capacity structures the behavior of regime elites. On the most basic level, regime elites are generally aware of state resource endowment, along with the

\footnotetext{
${ }^{5}$ For a more detailed discussion on the art of state theorizing, see Chapter 2.
} 
ways in which these resources have been accumulated and deployed in the past. Thus, it should not come as a surprise that a given regime's leadership corps knows the size of their military, its level of sophistication relative to neighbors in the region, and whether it is constructed with primarily offensive or defensive advantage in mind. Regime elites will also be intimately aware of how the military has been used historically, along with the corresponding outcomes of past operations. In short, they will know whether the military been used primarily to fight internal and external wars, for providing security, or stifling domestic dissent.

Similarly, it can be assumed that regime elites possess an understanding of how their non-military bureaucracies operate. Even if they remain largely isolated from the public, said elites have a rough estimate of the quality of public service delivery, and how regime preferences have been translated into actual policies. This is not to say that leadership cadres are not sometimes deceived by bureaucrats or fall prey to fits of delusion by imagining that their administrative bureaucracy is more effective than it is (Gandhi and Przeworski 2007, 1289). While acknowledging the possibility of cognitive error or bias, I propose that regime elites have a rough idea of state resource endowment. In this respect, I assume that autocrats-like all leaders-generally confront threats rationally, even when they do not possess perfect information (Wintrobe 1998, 5).

With a basic awareness of the relative strength of the military and civilian bureaucracy, regime elites understand the sorts of tools at their disposal for containing threats emanating from civil society. In the authoritarian context, the main objective of the regime is survival, as by its very nature it lacks the other type of legitimacy conferred 
by free and fair elections and adherence to the rule of law (Kinne 2005). Under authoritarianism, threats from below are frequently associated with actors and organizations that pre-date the regime itself. Such regimes, typically lacking the overwhelming social power of their totalitarian counterparts, are incapable of destroying these entities, and consequently are tempted to take actions meant to ensure that the latter do not instigate a popular uprising or whittle away the regime's material or symbolic power over time. Corresponding literature on the nature of authoritarian regimes is covered in more detail in Chapter 2.

When faced with challenges emanating from organized religion, authoritarian regime elites will typically employ strategies intended to marginalize challengers. This may be pursued through cooptation, where the regime seeks to bring religion under its wing through political patronage or systemized bribery. Regimes most effective at employing this strategy will convincingly fuse official regime ideology with that of the sponsored religion, while protecting the latter against the intrusion of disruptive elements. The Malaysia and Burma cases serve as two very different illustrations of this phenomenon, as the former's electoral authoritarian regime has effectively promoted its version of Islam in a manner consonant with the belief system of the religious majority, while simultaneously marginalizing rival ideologies. Conversely, the "Burmese Way to Socialism", engineered by a military regime desperate for popular legitimacy, never fused Buddhism and socialism together in a way which could convincingly appeal to both the sangha and masses. 
Under circumstances where cooptation is either never attempted by the regime, or is attempted and fails, coercion emerges as the only other option available to suppress would-be challengers. Here, coercion pertains to violence, real or threatened, resulting in material punishment (psychological or physical), detainment, or death. Such actions taken against religious organizations are not entirely uncommon, particularly in the Southeast Asian context. Because of the 1988 and 2007 revolutions, hundreds of Buddhist monks in Burma were jailed or killed, stemming from their participation in antiregime protests. Additionally, the periodic ideological "purification" of the sangha, where certain monasteries are closed, or individual monks de-robed, frequently because of subversive political activity, has been an enduring feature of Burma under military rule (Than 1998). And sangha purification is by no means unique to Burma, as it has also taken place in Thailand, Laos, and Cambodia at different points in their modern history.

While coercion applied against religious organizations may resolve the most immediate fears of a regime, namely, the possibility of an incipient revolution or at the very least a budding resistance movement, violent crackdowns against symbolically important institutions are unlikely to yield long-term political or social stability. As a result, periods of repression are sometimes followed by an era where regime elites make a concerted effort to patronize religion. This was certainly the case in Burma, as the violence of the 1980's gave way to the regime's public dedication of pagodas in the 1990's, culminating in the 1994 construction of a pagoda containing the Buddha's "tooth relic" (Schober 2007). In a similar fashion, after the destruction wrought by the Khmer Rouge during the previous decade, the Cambodian communist regime decided to revive Buddhism in the 1990's, eventually making it the official state religion. This abrupt 
policy about-face, though almost certainly intended as a move to leave Pol Pot's genocidal ideology behind, was nonetheless surprising behavior for a forthrightly communist regime.

This dissertation proposes that it is elites embedded in regimes who ultimately make important policy decisions. As such, it would be both inaccurate and disingenuous to suggest that state capacity alone shapes the behavior of political actors. In a complex environment, political elites clearly make decisions with multiple considerations in mind. To further complicate matters, it occasionally happens that these elites misinterpret the intentions of adversaries or rationalize decisions post facto. For these reasons, it is not my aim to engage in individual-level psychological analysis of elite decision-making vis-àvis religious organizations. As this dissertation operates on the macro-level of analysis, the individual personality traits of elites, both within the regime and religious organizations is of secondary importance. Rather, my analysis relies on two very basic assumptions about political elites in authoritarian regimes. In short, regime elites put a premium on both their own survival (political and physical), and the perpetuation of the regime itself. In the authoritarian context, these two goals are typically closely aligned as the breakdown of the regime frequently leads to the death, imprisonment, or exile of the leadership cadre.

Instead, state capacity is argued to shape the range of decisions available to regime elites. In spirit, this is a structuralist argument, and as such, it makes careful, 
narrow claims about specific political outcomes ${ }^{6}$. As this research engages in deductive "middle range" theorizing: results are uncertain and conclusions are falsifiable, though the domain of the findings may be limited. This dissertation is novel with respect to its interest in investigating the relationship between the state, regimes, and religious organizations. In short, I ask whether the former decides to co-opt or coerce the latter is shaped by its degree of state capacity. Here, the state largely functions as a historicallyconstituted entity that is not easily altered by any given regime. Almost by definition, strong and weak states differ in their power over society.

This dissertation will demonstrate through historical comparative case-study analysis $^{7}$ that a regime leader's choice to co-opt or coerce organized religion is not merely based on the whims of a given leader. While a given regime may feature a powerful unifying ideology, or uniquely charismatic ruler, this is often an insufficient explanation for the actual strategies these regimes employ against religious organizations. For example, one may ask what explains the wide variation in strategies undertaken by southeast Asian Marxist regimes against religious entities? Alternately, why have regimes in Thailand and Malaysia, two states with different religious and political traditions, taken very similar approaches to the management of organized religion? I argue that a compelling answer to these questions points to differences in state capacity, as stronger states have the luxury of choosing between repression and "softer" forms of

\footnotetext{
${ }^{6}$ This is done to avoid the problem of over-determination, whereby theories are crafted in such a way that already preclude the possibility of alternative explanations.

${ }^{7}$ For more on comparative methodology, see Chapter 2.
} 
organized cooptation, while their weaker counterparts must often resort to the indiscriminate use of force to maintain order and may not be effective in doing so.

As alluded to earlier, this dissertation engages in a novel approach to understanding the relationship between state and society. In this respect, it builds upon research in the Neo-Weberian tradition which views the state as an actor conceptually and analytically distinct from political society. The literature on state theorizing is voluminous and is synthesized in Chapter 2. While for theoretical purposes this dissertation understands the relationship between states and regimes in a top-down manner, it attempts to avoid the pitfall of functionalist accounts, by making it clear that society's role is not merely to fulfill the needs of the state. In earnest, state and society form a complex web of interaction. As the true relationship between state and society is multidimensional, empirical social science recognizes the necessity of observing an intentionally limited range of phenomena. In this respect, theories should be parsimonious, testable, and generalizable. Any theory that is crafted for the explicit purpose of explaining one case, runs into the problem of anomaly, while leaving little room for measurement error. Conversely, certain grand theories, often offering broad claims not readily amenable to empirical verification, become difficult to either prove or disprove at such a high level of abstraction.

This dissertation makes use of controlled comparison as a means of limiting the number of possible variables in order to reduce the number of alternative explanations and the corresponding problem of equifinality, whereby multiple causal paths ultimately lead to the same outcome. In Comparative Politics, controlled comparison is far from a 
perfect science, as no two cases are precisely the same. When comparing states, it is not always possible to fully control for historical contingencies such as war or regime change. Yet, through employing a most-similar-systems-design it is possible to reasonably control for obvious incommensurability between cases. In this dissertation, cases are selected based upon the features which are most likely to impact my research. In terms of state capacity, all cases exhibit variation on the independent variable state capacity, and its constituent parts, coercive and bureaucratic/administrative power. Secondly, all states can be classified as authoritarian, from 1945 to the present. As such, this dissertation does not plan to closely examine state/society relations in either liberal democracies or totalitarian regimes. In the first case, the rule of law and influence of rival elites curbs a democratic regime's ability to either co-opt or coerce religious organizations. Under totalitarianism, all civil society, including religious organizations, are under the strict control of the regime. In such a scenario, there is no need for cooptation, as a more coercive system is a defining component of the totalitarian regime (Linz and Stepan 1996).

The choice to study authoritarian regimes is not accidental, as it provides the most compelling context for the struggle between regimes and civil society to take shape. This is not to assume that all authoritarian regimes are the same, only that they do inevitably provide a limited amount of space for civil society groups to contest the state. Thus, a harder form of authoritarianism in Laos can and should be directly contrasted against a competitive authoritarian regime type in Malaysia. While understanding different political dynamics within the authoritarian category are important for both theory and application, my research suggests that such differences do not have a meaningful impact 
on my results. In fact, no regime in my universe of cases is sufficiently democratic to change the fundamental dynamic of contestation between regimes and organized religion. In other words, even in Malaysia, the most democratic of the region's non-democracies, the regime still exerts considerable pressure on civil society, with attention devoted to the control of organized religion.

Finally, it is my choice to study the most visible religious organizations in Southeast Asia, as judged by membership and influence. It is my assumption that these groups by their very nature would pose the greatest threat to the regime, and as such are likely to be the main targets for cooptation and/or coercion. While violent crackdowns and bribery targeted at religious minorities are not uncommon in autocracies, this important dynamic has already been well trodden in the political violence and ethnicity literature. In the interest of mitigating the levels of analysis problem, the behavior of individual religious organization leaders will be largely omitted from this dissertation. Rather, the focus will be on macro-level patters, namely, whether and by what means an organization as whole has been co-opted or coerced by a regime over the course of several decades.

In order to best study variation in my independent and dependent variables across time, this research employs careful analysis aided through secondary literature and archives. With respect to the former, literature in Comparative Politics, Area Studies, Sociology, and Religious Studies provides me with the resources required to better understand the complex relationship between states, authoritarian regimes, and religious organizations over time. Archival research conducted at Stanford University's Hoover 
Institution reveals interesting insights on the regime/religion nexus across several Southeast Asian cases. Specifically, diplomatic correspondence conducted during the height of the Cold War, along with the records of the Asia Foundation reveal the extent to which Buddhism in Southeast Asia was subject to the ideological tug of war between communism and capitalism. Here, primary source documentation provides me with the historical context surrounding the contentious relationship between religion and politics in post-independence mainland Southeast Asia.

In this dissertation, I engage in a deliberate choice to resist employing a classical process-tracing methodological approach, as comparisons ranging over the course of several decades are unlikely to reveal a neat sequential pathway linking state capacity to specific policies undertaken by regime elites against religious organizations. As George and Bennett (2004) keenly observe, "In using theories to develop explanations of cases through process-tracing, all the intervening steps in a case must be predicted by a hypothesis, or else that hypothesis must be amended-perhaps trivially or perhaps fundamentally-to explain the case" (George and Bennett 2004, 207). With this caveat in mind, this research relies upon analytic explanation, whereby a historical narrative is intentionally placed within the purview of an explicit theory in the interest of detecting casual patterns (Ibid 2011).

While George and Bennett classify analytic explanation as a variety of processtracing, it should not be mistaken for the more orthodox form of process-tracing discussed earlier. The research as such is selective and does not aim to provide an 
exhaustive explanation of state/society relations, but rather a narrower explanation put forth through careful theorizing and hypothesis generation.

\section{Concepts and Operationalization}

As this dissertation features many terms that have different colloquial meanings, it is important to define and operationalize concepts with great care. I begin with the concept of state capacity which has been employed, sometimes carelessly, to connote good governance, or adherence to democratic norms and market-driven economic policies. Instead, I rely on Theda Skocpol's minimalist conceptualization of state capacity as the state's ability to "implement its official goals" (Skocpol 1985 8-9). Neo-Weberian scholars have observed that the state itself is not monolithic and can often feature high capacity in some policy areas, while demonstrating low capacity in others. This is a very common phenomenon in much of the global south where states with relatively strong militaries do not possess correspondingly strong civilian bureaucracies. Whether this type of uneven state development is a consequence of the regime's own prerogatives, or the historical influence of foreign actors, certainly varies on a case-to-case basis. For my research, making clear that a conceptual, analytical, and practical distinction between types of state capacity exists is an essential step toward unearthing the types of strategies regimes are most likely to employ against religious organizations.

For the aforementioned reasons, state capacity will be operationalized along two different dimensions: coercive capacity and bureaucratic/administrative capacity. The former is conceived in terms of resources available for compelling citizens into 
compliance with a given regime's policy agenda (Mann 1984, 118). ${ }^{8}$ In the simplest terms, this is, at least in part, evidenced by a state's investment in military spending coupled with the size and sophistication of its military forces. The latter distinction is critically important as states which feature many troops may not invest large sums of money in modernizing these forces. Correspondingly, a given regime may feature a smaller standing army, but could have made a considerable investment in sophisticated weaponry.

Bureaucratic/administrative capacity pertains to a given state's ability to distribute goods and services throughout society. Implied in this concept is the presence of a centralized and rationalized state bureaucracy capable of penetrating society (Mann 1984, 190). Therefore, those states incapable of effectively delivering goods and services beyond a small geographic area, typically the capital, are clearly lacking in bureaucratic/administrative capacity. Goods and services include those resources that are public by nature, including, physical infrastructure such as roads, electricity and water delivery systems, but also education and vocational programs.

While a wide variety of state capacity measures exist, for this project, it is important to justify why certain indicators were selected over others. While Michael Mann's disaggregation of state capacity into two constituent parts, despotic and infrastructural power is conceptually useful, it is difficult to operationalize these terms in practice. Specifically, Mann's notion of despotic power does not translate to any direct

\footnotetext{
${ }^{8}$ Mann employs the term despotic power to describe the same phenomenon. This dissertation identifies this dimension of state capacity as "coercive capacity". For more on Mann's theorizing see Chapter 2.
} 
measure of state power as it is cited as the" ability of elites to impose their will over subjects" (Mann 1984, 113). While this definition readily conjures the image of a strong or potentially oppressive military willing to quash civil dissent, Mann intends to elicit a more comprehensive understanding of this dynamic. Here, despotic power also implies a regime's ability to enact a broader set of policies with little to no resistance from the population. Conceivably, coercive economic policies, such as forced agricultural collectivization or punitive industrial quota systems, such as those featured in Stalin's Soviet Union or Mao's China would also suggest a high degree of despotic power.

Mann's other influential concept, infrastructural power, portends a regime capable of penetrating society through the presence of a strong state bureaucracy. In his historical analysis, Mann shows how infrastructural power has evolved, culminating in the presence of modern/rational bureaucratic systems capable of delivering important goods and services to citizens with a high degree of efficiency. Yet, infrastructural power also envelops the related, but distinct concept of fiscal capacity. States with the ability to predictably extract taxes from their citizens can in turn bolster the strength of their civil and military bureaucracies.

As this dissertation focuses on a given regime's ability to employ state resources as a means of coopting and/or coercing prominent religious organizations, it may seem advisable to use a state's ability to collect tax as a proxy for its strength. Yet, this sort of choice comes with a high risk of tautological reasoning, as a strong state would presumably require a strong bureaucracy in order to effectively collect tax, and then use it for repression. In this respect, it is hard to justify extractive capacity as a stand-alone 
measure. Instead, tax collection should at best be seen as a policy which strong bureaucratic states are better able to implement. As a feature of bureaucratic/administrative capacity, it is too deeply intertwined with other elements of state power to remain analytically distinct. Furthermore, it is very difficult to determine how much tax a state could tax, versus how much it collects without getting into broader normative questions about the proper economic role of the state.

While Mann's concept of infrastructural power is close to the term bureaucratic/administrative capacity in spirit, the former might be misleading in strictly linguistic terms. Mann's intentionally broad understanding of infrastructure pertains not just to physical structures, but also a regime's overwhelming power to completely infiltrate society, of which the former is just a means to an end. In this respect Mann's concept implies a vast policy regime at the heart of its power. While this is admittedly a more accurate portrayal of state functionality, it does not lend itself to neat conceptual operationalization. In other words, it is far more difficult to find suitable indicators for infrastructural power than the narrower concept of bureaucratic/administrative capacity.

Critics of the state capacity literature are quick to assert that it is impossible in practice to disentangle the capabilities of the state from the policy prerogatives of regime elites. For example, a given regime may selectively distribute its resources to favored groups at the deliberate expense of ethnic or political rivals. While this is undoubtedly true, a regime still must contend with historical realities of state development. Though it may craft policies or engage in behavior that is ultimately politically or economically counterproductive, it can do comparatively little to dramatically enhance or deplete the 
power of the state, at least in the short-term. In other words, what a regime chooses to do with its resources is a matter of policy, while the overall quantity and quality of those resources remains largely determined by broader historical processes over which it has little control. As regimes inherit their states, it is important to clarify that they are not wholly ontologically separate from the state itself. Yet, at the same time the regime and the state are not mere synonyms, a subject discussed at length in the following chapter.

\section{On Typological Theorizing}

The analytical methods utilized in this dissertation rely heavily on the insights of typological theory. Good typologies are not intended to explain all political phenomena, nor do they discount the possibility for anomalous cases. In this sense they are meant to be general, and do not propose strictly deterministic explanations. In other words, a typology seeks to capture an important empirical pattern, without suggesting that it is the only explanation for a specific casual event. In this sense, it remains ontologically open to the possibility of both equifinality and multifinality (Bennett and Elman 2006, 466). With this caveat in mind, it should also be said that typologies attempt to account for alterative explanations early in the research process through careful design, to minimize the possibility of hidden causal variables emerging later on in the research project.

Typological theorizing also makes explicit theoretical propositions for explanatory purposes. For example, apart from simple classification, typologies attempt to reveal relationships between variables (ibid). Oftentimes, these relationships are complex and serve as a better reflection of reality than those put forth by simple linear arguments. Finally, typologies, by deductively setting forth parameters for a hypothesized 
relationship, should make the case selection process more rigorous. Here, there is less risk that cases will be selected based on researcher bias as it should be fairly easy to detect those cases that do not belong in the typology. Through establishing a spatial and temporal scope within the typology itself, there is a smaller risk of overgeneralization, as the researcher can more easily identify their universe of cases, by focusing on those quadrants that are most applicable to case-study research (ibid 467-468).

This research design applies an existing typology in a new way, and as such engages in a theory-building exercise. The typology does not intend to posit a perfect causal relationship between state capacity and regime/religious organization strategy. Rather, state capacity structures the range of choices available to the aforementioned groups. The relationship between the variables is probabilistic, suggesting that coercive and bureaucratic/administrative power influences regime and religious organization strategy most of the time. In the spirit of typological theorizing, there is no dogmatic intention to dismiss out-of-hand other robust explanations for a given outcome, such as the significance of regime ideology or the personality traits of leaders. Instead, it is my intention to demonstrate that state capacity provides a more convincing explanation for regime strategy toward religious organizations than either ideology or individual psychological attributes alone.

Methodologically, this research takes a qualitative, comparative approach. The most- similar-systems-design is employed as the cases under consideration all share important historical and political similarities. In short, the most-similar-systems design is utilized to compare similar cases in the interest of finding how cases differ on the 
outcome variable. On the topic of MSSD, Przeworski and Tuene (1970) write, "it is anticipated that if some important differences are the found among these otherwise similar countries, then the number of factors attributable to these differences will be sufficiently small to warrant explanation in terms of these differences alone" (Przeworski and Tuene 1970, 32). When engaging in a most-similar-systems-design case selection proves to be critical, as the inclusion of one or more dissimilar cases creates the possibility for alternative explanatory or intervening variables to emerge. My case selection permits more opportunities to detect important variations on the dependent variables; specifically, the decision for a regime to coerce/or co-opt religious organizations. Qualitative historical-case studies aim to uncover the complex relationship between state capacity, regime strategy and religious organizations through an exhaustive examination of the secondary literature. This case study research also permits contextual comparison, permitting a more nuanced understanding of hypothesized relationships.

In the final chapter, the number of cases will be expanded to further examine the strength and complexity of my hypothesized relationships. Select cases from Latin America, Africa, and Eastern Europe will be briefly analyzed using the same framework. In the spirit of the Most-Similar-Systems design, these cases will be selected based upon their values on the independent variable, specifically levels of coercive and bureaucratic/administrative power. 


\section{Coercive Power}

Low

High

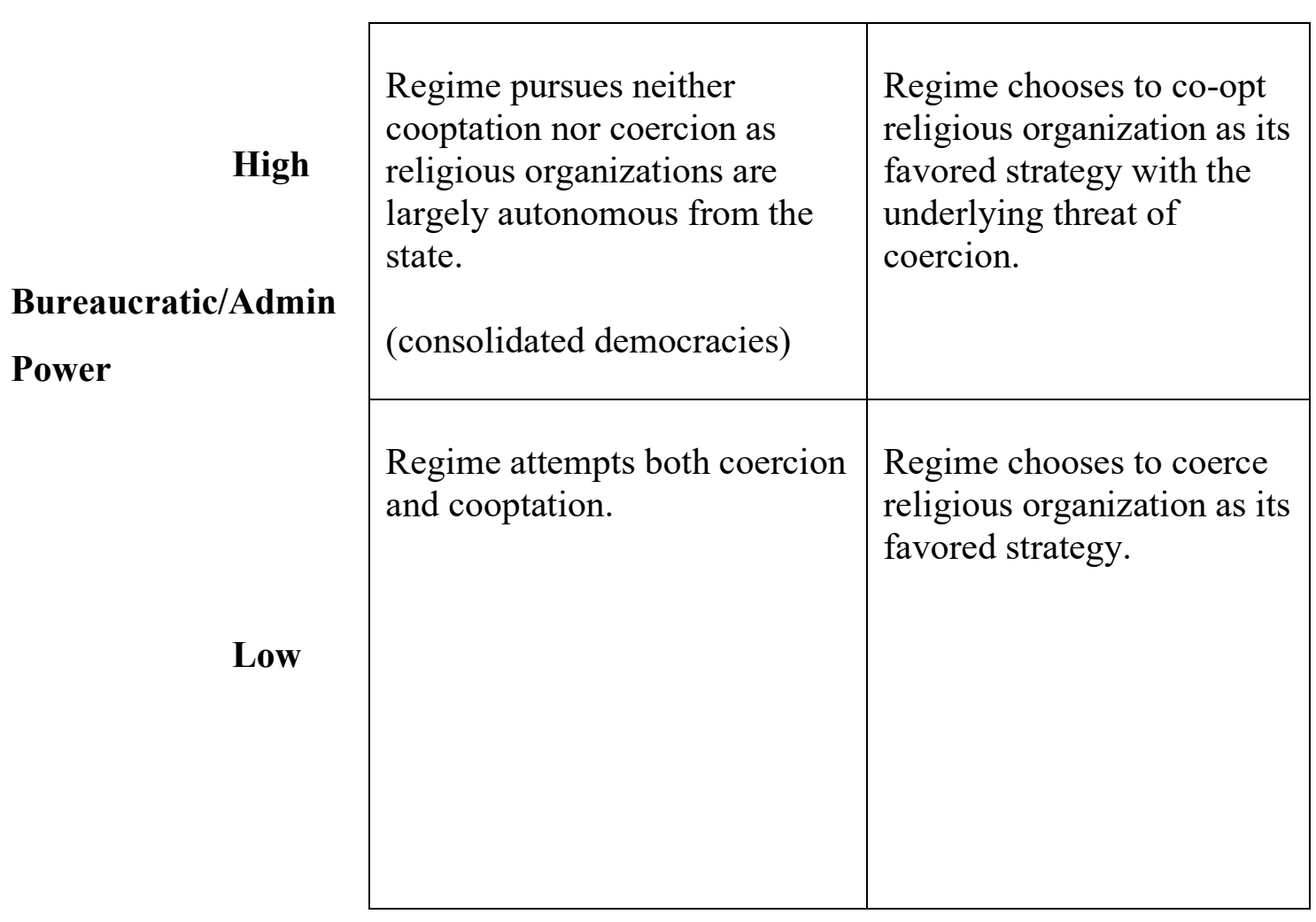

Table 1 represents a typology of state capacity as defined by its stock of coercive and bureaucratic/administrative power. I propose that a regime's decision to co-opt or coerce is shaped by its own estimates of the aforementioned power resources. Crucially, this typological theory is crafted in such a way to allow for variation in strategies under the same regime. For example, regimes embedded in states with high degrees of both bureaucratic/administrative and coercive power will likely choose cooptation as its 
preferred strategy, while it still can resort to the former under the unlikely scenario where it deems the use of force necessary to repress a domestic challenge to the state.

As the upper-left quadrant illustrates, democratic regimes are rich in infrastructural power but low on despotic power as they typically require the consent of the governed to impose their will. Since this dissertation limits itself to the authoritarian context, democracies (most likely to appear in the left upper quadrant) will not be considered here.

Measuring State Capacity, Regime Strategy, and Religious Organizations

There are at least two major challenges inherent to the study of state capacity: conceptualization and measurement. It is essential to be precise and disentangle state capacity from other related phenomena like institutional performance, good governance, and regime power. In order to accomplish this task, one should evaluate previous scholarship in the interest of retaining state capacity's core elements, jettisoning unnecessarily complex terms that do not lend themselves to empirical analysis. Good governance is a normatively laden term, which fails to attend to both the despotic and infrastructural dimensions of state capacity. These indicators evaluate a broad range of economic and political structures, and as such are not defined narrowly enough to capture important distinctions between different types of state capacity. Regime power is more reflective of the group who is running the state. Over time, regimes can build or destroy the state through certain policies, but the range of policy options is already contingent on preexisting state capacity. Thus, a regime may either enhance or deplete its military resources through chosen policies, but it is far less able to create an advanced military 
from scratch. The strength or weakness of given states are shaped by a much longer time horizon, stretching as far back as the precolonial era in much of the developing world.

In terms of measurement, researchers must be sensitive to basic validity and reliability problems. Do variables operationalized in a given data set closely correspond to the concept under study? Are coders transparent about missing data, and the ease of comparing data across time and space? Finally, what are some of the limitations inherent to comparing different indicators in various data sets? While there is no straightforward solution to these problems, thorough case study research may help shed light on how closely the quantitative data meshes with accumulated historical knowledge.

As for data collection, state capacity cannot simply be understood through a study of policy outputs. Policy, though influenced by state capacity, (there are certain policies that weak states are incapable of implementing), reflects a given regime's choice. Regimes with high state capacity may not need to use coercive force frequently, as their power is already taken for granted by would-be challengers. Similarly, a state with high infrastructural power may refuse to collect taxes or provide other resources to certain groups as a means of distributing patronage. Since analytically separating a given regime's policy choices from state capacity can be challenging, historical case-studies are required to better contextualize indicators for policy output.

A related difficulty in measuring state capacity stems from a lack of temporal and geographic coverage in available data sets. While some sources include data over an extended time period, others offer only snapshots. This problem is more evident with infrastructural power indicators, as it is exceedingly difficult to find data that stretches 
back more than 25 years. Notwithstanding these caveats, existing datasets such as those found in the Association of Religion Data Archives do serve as in important guide to understanding the complex relationship between states, regimes, and religion (ARDA 2017). This measurement of state sponsorship, or alternatively, repression of religion will be discussed more thoroughly on a case-by-case basis. Suffice it to say that all regimes in the region have actively and continue to interfere in the religious activities of their citizens, as a matter of degree.

For the purposes of this dissertation, state capacity is imagined in terms of both coercive power-or the ability for the state to credibly compel citizens into complianceand bureaucratic/administrative power-or the state's ability to penetrate society through an effective bureaucratic apparatus. While multiple indicators for measuring each component of state capacity exist, no single indicator provides completely adequate geographical and temporal coverage. Therefore, several indicators will be utilized in the qualitative case study portion of the dissertation. For coercive power, the World Bank's military capabilities dataset will be consulted as a rough indicator of the size of a given state's military in thousands of troops annually, as well as the percentage of annual GDP spent on military affairs. One limitation inherent to the World Bank data is a lack of temporal coverage dating back to the immediate post-independence era. There is also data missing for periods of intense warfare, affecting the study of Cambodia, Laos, and Vietnam. While this places limitations on longer-term comparisons, recent data stretches back far enough to provide a general enough idea of how different states in the region rank in terms of military capabilities. 
In terms of bureaucratic/administrative power, the Worldwide Governance Indicators provide aggregate and individual data for 215 countries from 1996-2014. Government Effectiveness is one of the aggregate indicators and corresponds closest to my definition of bureaucratic/administrative power. Government Effectiveness measures perceptions of public service delivery, civil service efficacy, and the quality of government policy implementation (Kauffman and Kray, 2017). Through the collection and coding of survey data as well as independent evaluations from a variety of INGO's, Kaufmann, Kray and their colleagues have created the aggregate score as means of tracking overall government effectiveness over time. The choice to use an aggregate measure is intentional, as disaggregated data in this dataset is assembled from different sources, and thus difficult to compare across cases. Secondly, the aggregate score reflects different variants of bureaucratic/administrative capacity including quality of infrastructure, educational attainment, and civil service meritocracy, which provides a more complete picture of how bureaucratic/administrative power operates in each state.

Finally, to assess which cases fall into the domain of authoritarian regimes, Freedom House's aggregate quality of democracy scores are offered as a snapshot, intended to show the presence of autocracy in each of the country-cases. While a wide variety of democracy indicators exist, Freedom House offers the most consistent and temporally relevant data. Through a battery of checklist questions, Freedom House assesses the quality of political rights and civil liberties present for individual citizens of each country. 
In the broader discussion of state capacity and regimes, it is important to also consider the role religious organizations play in my hypothesized relationship. A preliminary review of the literature suggests that such organizations are not passive actors, but actively seek opportunities to extract resources from their regimes and sympathetic patrons. In this sense, cooptation occurs when a given religious organizations' leadership receives certain material benefits in exchange for regime support. Cooptation itself varies according to context, as religious leaders may assume actual political roles in government, while others receive targeted financial support. Though certain religious organizations are willingly coopted, others will deliberately decentralize as a means of evading the state. These religious organizations may also reach out to international donors as a means of building financial autonomy from the state. Since these strategies are highly contextual and depend on complex historical relationships with the state, and existing cross-national data on religious groups (Pew Research Center 2016; Fox and Flores 2009) tends to focus on state policies rather than the religious organizations themselves, case-study analysis is the best tool available to observe change over time and variation across countries and groups.

\section{Hypotheses}

The following hypotheses outline the proposed relationship between state capacity and authoritarian regime strategy ${ }^{9}$. Regime elites in states enjoying high levels of coercive power and low levels of bureaucratic/administrative power to coerce religious

\footnotetext{
${ }^{9}$ The relationship between states, regimes, and religious organizations in democracies is beyond the scope of this research. Therefore, I do not present a corresponding hypothesis in this proposal.
} 
organizations, as they have few resources at their disposal for cooptation. In this context, coercive regime elites are inclined to intimidate, jail, or kill religious leaders since buying off potential opposition is perceived as too expensive. Conversely, governing elites in states with high levels of both coercive and infrastructural power will choose cooptation, if it is less costly than coercion. Cooptation is less likely to provoke the anger of domestic citizens and international observers. Should cooptation prove less than successful, such regimes can still employ coercive force as a secondary strategy. My third hypothesis argues that regime elites in states with low levels of coercive and bureaucratic/administrative power will attempt a mix of coercion and cooptation, as no single strategy is likely to be particularly effective. In these weak states, the regime has reason to fear religious organizations as it has few resources to check its growth and influence as an alternative locus of power.

H1. Regime elites in states with high levels of coercive power and low levels of bureaucratic/administrative power choose to coerce religious organizations.

H2. Regime elites in states which possess high levels of coercive and bureaucratic/administrative power prefer to coopt religious organizations.

H3. Regime elites in states with low levels of coercive and bureaucratic/administrative power engage in a mixture of cooptation and coercion. 
Figure 1: State Capacity, Regime Strategy, and Religious Organization Strategy

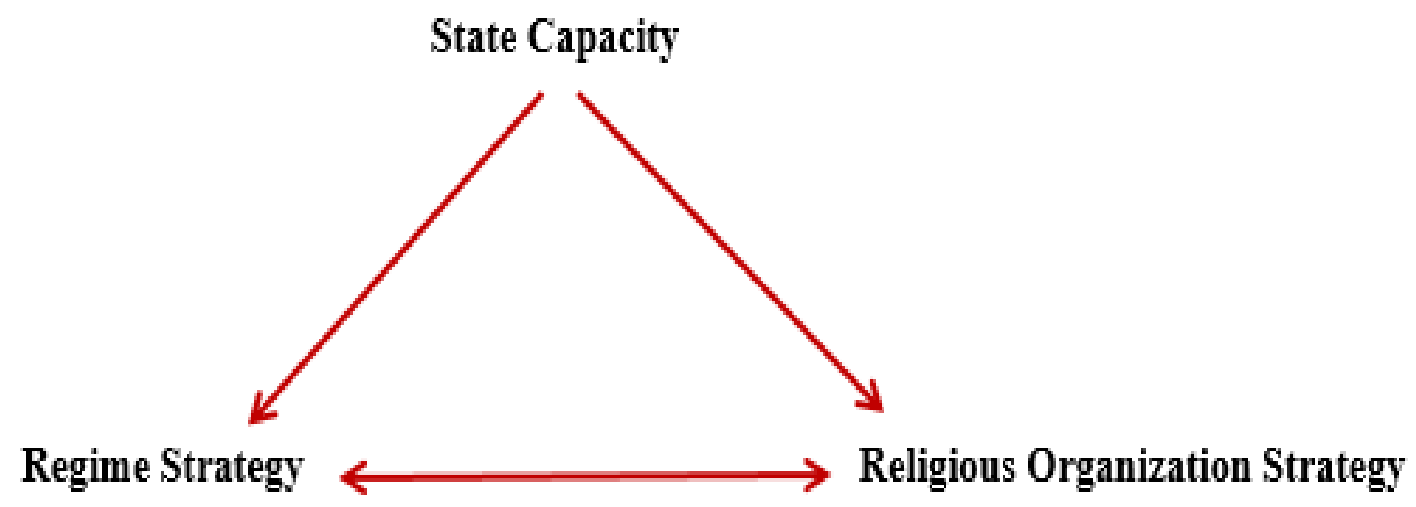

Figure 1 illustrates how state capacity influences the strategies regime elites will take toward religious organizations. It also shapes the strategy of religious organizations, as they have a rough idea through historical experience of how they can interact with the regime. Regime elite strategy and religious organization strategy are interdependent; the actions taken by one group will affect the actions taken by the other.

The relationship between state capacity, authoritarian regime elite strategy, and religious organizations is dynamic and fluid. The triangular relationship specified in Figure 1 demonstrates the complexity of the power relationships among these groups. For my analysis, I focus specifically on how state capacity shapes the ways in which authoritarian regimes relate to religious groups. 
In the consideration of actual cases, states in the region were selected according to their values on different indicators of coercive and bureaucratic/administrative power. What follows is a description of where states are expected to be in the typology based upon preliminary research. Historical case-study research will add an important temporal dimension, showing the process of state development from the post-independence era to the present. While state capacity is not expected to fluctuate widely over time, periods of crisis can either strengthen or weaken the coercive and bureaucratic/administrative capacities of a given state. For example, while warfare enhanced the Burmese state's coercive power in the immediate post-independence era, civil war has gradually weakened it over time, despite its large and well-funded military apparatus. Here, expansion into ethnic-minority states has attenuated the military's power, stretching its resources thin in those regions which have always been capable of escaping state control (Scott 2009). Conversely, low-level counterinsurgency operations undertaken by the Malaysian government enhanced its coercive and bureaucratic/administrative power over time, as the "emergency" era provided an ad hoc justification for largely successful state military and bureaucratic expansion into previously ungoverned areas. A similar process of internal colonization also contributed to an increase in coercive and bureaucratic/administrative power in Thailand, albeit over a longer time horizon and with fewer episodes of state-sponsored violence. ${ }^{10}$ Fluctuations in state capacity over time in

\footnotetext{
${ }^{10}$ The key exception is the ongoing violence in southern Thailand between the Thai government, ethnically Thai nationals and ethnic Malays.
} 
Cambodia, Laos, and Vietnam are complex, in large part due to the legacy of the Vietnam War, and will be explained in more detail on a case-by case basis in latter chapters.

Table 2: Authoritarianism in Southeast Asia

\begin{tabular}{|l|l|l|l|}
\hline Country & $\begin{array}{l}\text { Type of } \\
\text { Authoritarian Rule }\end{array}$ & $\begin{array}{l}\text { Authoritarian } \\
\text { Duration }\end{array}$ & $\begin{array}{l}\text { Freedom House } \\
\text { (2017) Score }\end{array}$ \\
\hline Burma & Military ${ }^{11}$ & 32 \\
\hline Thailand & Military & $\begin{array}{l}1947-73,1976- \\
1991,2006-7,2014- \\
\text { present }\end{array}$ & 32 \\
\hline Laos & Marxist-Leninist & 1975 -present & 12 \\
\hline Cambodia & Marxist-Leninist & 1975 -present & 31 \\
\hline Vietnam & Marxist-Leninist & 1975 -present & 20 \\
\hline Malaysia & $\begin{array}{l}\text { Competitive } \\
\text { Authoritarian }\end{array}$ & $\begin{array}{l}1948-57,1960- \\
\text { present }\end{array}$ & 44 \\
\hline
\end{tabular}

The information presented in Table 2 provides an indication of a long history of authoritarian rule across the six Southeast Asian cases. The lower the score, the less a given regime respects political rights and civil liberties. While authoritarianism in each of the cases has its own unique features, bringing attention to the general similarities is useful for classification purposes. Burma has the longest period of uninterrupted authoritarian rule, stemming from General Ne Win's 1962 coup, while Thailand has

\footnotetext{
${ }^{11}$ Burma's current regime (2015-present) is undergoing an uncertain political transition and cannot be readily classified as either fully authoritarian or democratic. While the current NLD ruling party was popularly elected in relatively free and fair elections, the country's military still retains autonomous power over key ministries, while possessing effective veto power in the legislature.
} 
experienced chaotic alternations between military and civilian rule for much of its modern political history.

The Marxist regimes in Laos and Vietnam emerged as a direct consequence of the second Indochina War, and have remained particularly durable since their emergence in 1975. Cambodia is unique among the Indochina cases as having endured two distinct Marxist regimes, first under Pol Pot's Khmer Rouge from 1975-1979, and then from 1981-present under the Cambodian People's Party.

Finally, Malaysia underwent a period of direct military "emergency rule" from 1948-1960 during an anti-communist guerilla campaign. From 1957 to the present, Malaysia has been ruled by two ethnic Malay majority parties, the United Malays National Organization, and the BN (Barisan National) coalition. While Malaysia cannot be classified as fully authoritarian, it has been characterized by single-party rule through a hegemonic ethnically-based coalition since independence. Rival parties could conceivably win national elections but are forced to compete on an uneven playing field, as the government controls media, intimidates opposition, and exerts undue influence on the judiciary. Apart from formal state power, Levitsky and Way (2010) observe, that the ruling UMNO party exercises several informal control mechanisms. They write "resources were overwhelmingly in the hands of the governing coalition". UMNO used its control of the state to build a "sprawling corporate empire" (Levitsky and Way 2010, $321)$.

In moving from the discussion of authoritarian regimes to religious organizations, it is important to identify the myriad ways in which the former attempts to keep the latter 
under its control. In each of the six Southeast Asian cases regime institutions are designed with this specific purpose in mind.

Table 3: Religious Organizations in Southeast Asia

\begin{tabular}{|c|c|c|c|}
\hline Country & $\begin{array}{l}\text { Major } \\
\text { Religion/Sect }\end{array}$ & $\begin{array}{l}\text { Major Religious } \\
\text { Organization }\end{array}$ & State Oversight Committee \\
\hline Burma & $\begin{array}{l}\text { Theravada } \\
\text { Buddhism }\end{array}$ & Sangha & $\begin{array}{l}\text { State Sangha Maha Nakaya } \\
\text { Committee }\end{array}$ \\
\hline Thailand & $\begin{array}{l}\text { Theravada } \\
\text { Buddhism }\end{array}$ & Sangha & $\begin{array}{l}\text { Sangha Supreme Council of } \\
\text { Thailand }\end{array}$ \\
\hline Laos & $\begin{array}{l}\text { Theravada } \\
\text { Buddhism }\end{array}$ & Sangha & $\begin{array}{l}\text { Lao Front for National } \\
\text { Construction }\end{array}$ \\
\hline Cambodia & $\begin{array}{l}\text { Theravada } \\
\text { Buddhism }\end{array}$ & Sangha & $\begin{array}{l}\text { Ministry of Cults and } \\
\text { Religious Affairs }\end{array}$ \\
\hline Vietnam & $\begin{array}{l}\text { Mahayana } \\
\text { Buddhism }\end{array}$ & $\begin{array}{l}\text { Buddhist Sangha of } \\
\text { Vietnam (State } \\
\text { Sanctioned) }\end{array}$ & $\begin{array}{l}\text { Committee for Religious } \\
\text { Affairs }\end{array}$ \\
\hline Malaysia & Sunni Islam & $\begin{array}{l}\text { Regionally } \\
\text { Decentralized }\end{array}$ & Ministry of Home Affairs \\
\hline
\end{tabular}

As Table 3 indicates, each major religious organization in the seven country cases is under the direct supervision of their respective states. Yet, as the case study chapters 
will further demonstrate, the degree to which the regime exerts control among these groups varies widely in practice. More specifically, the range of regime control over religion ranges from state-sanctioned religion in Vietnam, where only one narrowly constructed Buddhist organization is recognized by the state, to a relatively more permissive environment in Laos, where both Mahayana and Theravada traditions are recognized.

Figure 2: National Military Personnel in 100,000's (Southeast Asia)

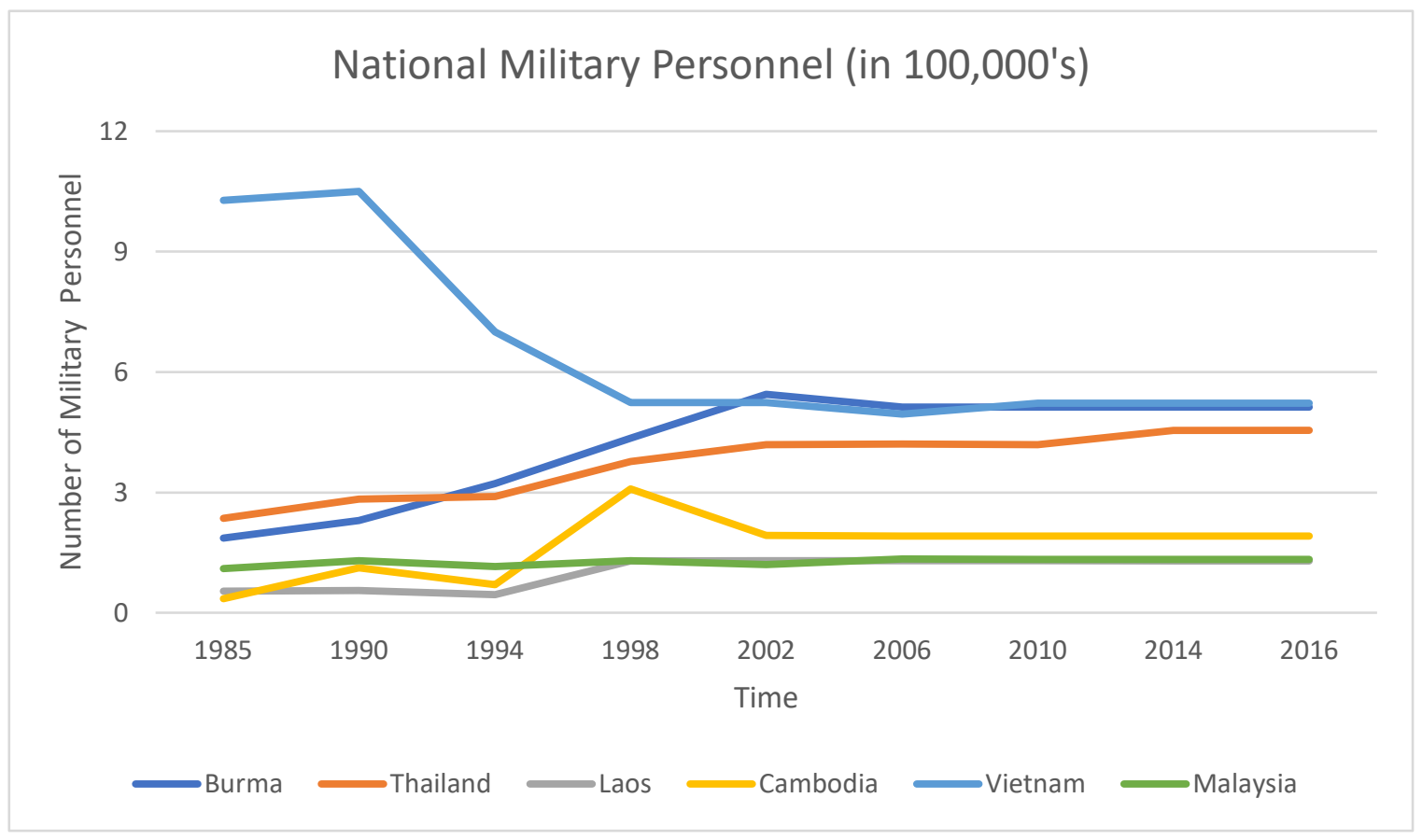

The number of military personnel assembled by the World Bank reflects changes in the composition of Southeast Asian militaries over time. Specifically, as Figure 2 indicates, the annual number of military personnel per country has grown in every state except for Vietnam, where massive post-war scaling down has occurred. Additionally, the size of the military has remained stable in Malaysia, likely a result of small-scale 
counter-insurgency operations in an otherwise conflict-free state. The sharpest increase in military personnel over the past 30 years has occurred in Burma beginning in the early 1990 's, peaking in 2002, then leveling off to its currently level, still remaining abnormally high by regional standards. This is almost certainly a reflection of two interrelated dynamics: high levels of ethno-religious conflict on the state's periphery coupled with the military regime's attempt to insulate itself from domestic political pressures beginning with the 1988 and 2007 pro-democracy uprisings. As Burma embarks on a tenuous transition away from autocratic rule, its military (numbering over 500,000 soldiers), continues to play an outsized role in society.

As a proxy for coercive power, a given state's national military capabilities (Figure 3) reflects its investment in formal military resources. While this does not fully capture the extent of a country's coercive power, as paramilitary and informal fighting forces are excluded from the data, it does provide a rough estimate of comparative military power across the region. As the table indicates, Vietnam and Burma have the largest militaries in terms of manpower. In both cases, the size of these forces is a direct consequence of a long history of violent conflict within the state. Thailand's large military reflects its historical legacy as a strategically important player during the Cold War era whereby it served as an important western bulwark against the spread of Communism in Southeast Asia. As such, it benefitted from a strategic alliance with the United States, whereby it became a locus for high levels of military spending and development. 
Large militaries were never developed in Cambodia not because of a lack of violent conflict, but rather due to their permanent status as states of secondary strategic importance, first under the French, and then under Vietnam's sphere of influence. In Cambodia, the Khmer Rouge's ability to swiftly take control of the central government in 1975, was indicative of a state with a poorly performing military apparatus. Similarly, the Pathet Lao came to power in the same year encountering little resistance from the central government. As the smallest country in the region, the Lao PDR features a much smaller army which mainly exerts its influence over Vientiane and the surrounding areas. Finally, Malaysia, features a surprisingly small army given its strategic importance in the region. However, part of the explanation may be due to the historical involvement of the military in small scale counter-insurgency operations, rather than full-scale military conflict.

\section{Figure 3: Military Expenditures as \% of Annual GDP}

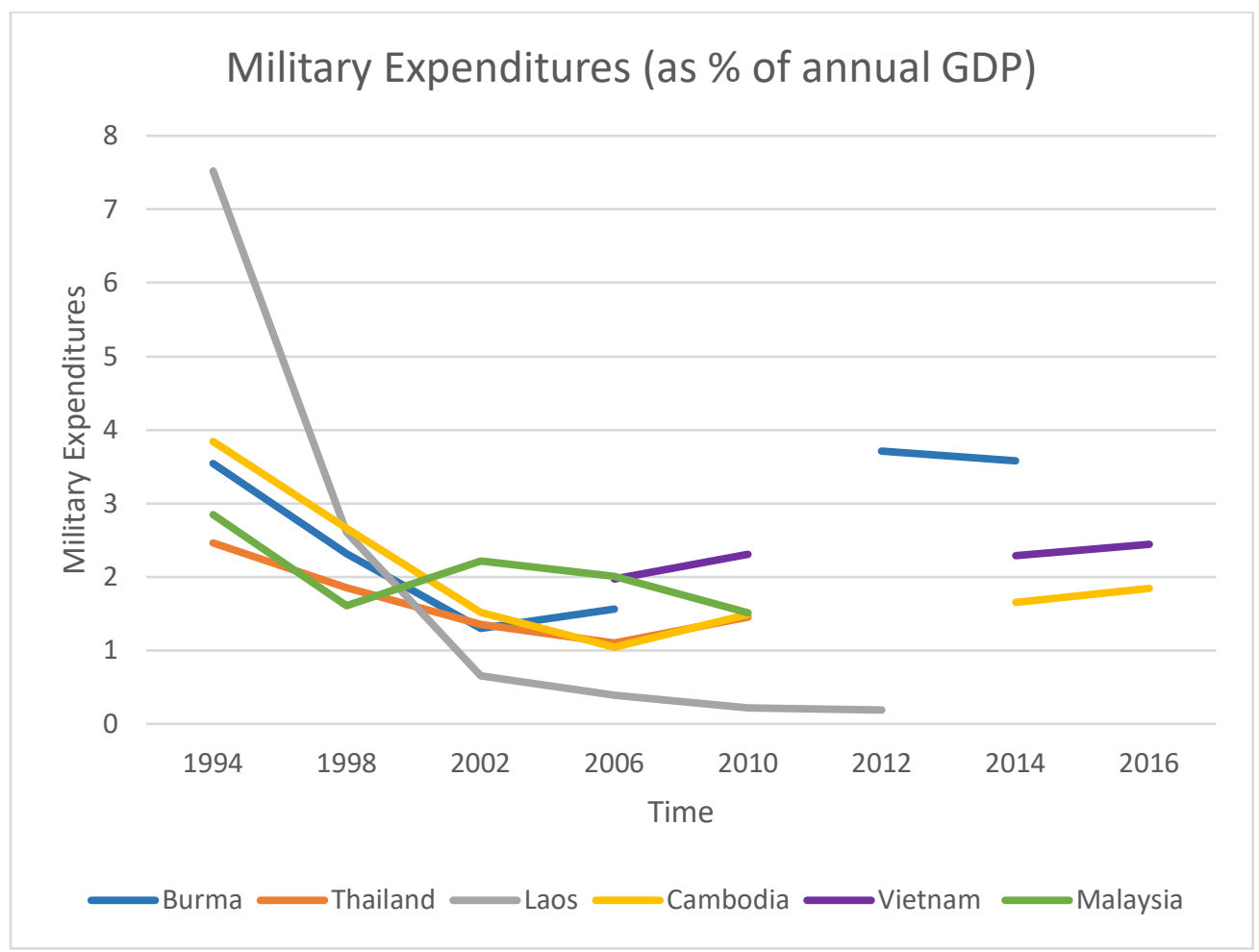


Table 4: National Military Capabilities

\begin{tabular}{|l|l|l|}
\hline Country & $\begin{array}{l}\text { Military Personnel (total) } \\
(2015)\end{array}$ & $\begin{array}{l}\text { Military Expenditure as \% } \\
\text { GDP }\end{array}$ \\
\hline Burma & 513,200 & $4.07(2015)$ \\
\hline Thailand & 454,550 & $1.4(2016)$ \\
\hline Cambodia & 191,300 & $1.8(2016)$ \\
\hline Laos & 129,100 & $.19(2013)$ \\
\hline Vietnam & 522,000 & $2.4(2016)$ \\
\hline Malaysia & & $1.4(2016)$ \\
& 133,600 & \\
\hline
\end{tabular}

In terms of military expenditures (Table 4), there is a noticeable contrast between the size of the military and the percentage of annual GDP allocated across states in the region. While Vietnam, Malaysia, and Thailand have the most sophisticated militaries in the region, they do not spend an outsized percentage of GDP on their armed forces. Laos and Cambodia spent heavily on their militaries in the 1990's, while cutting back in recent years. Burma's spending appears to be on par with the size of its military, though alternative accounts have recent expenditures in Burma to be even higher than this data indicates (Lwin, 2014). Finally, it should be mentioned that the sharp decreases in military spending for Cambodia, Laos, and Vietnam from the 1990's forward, is most likely a reflection of changing security dynamics in the region. The peace dividend 
brought about by at least two decades without war has resulted in a predictable decrease in military size and expenditure.

The Worldwide Governance Indicators, assembled by Kauffman and Kray (2017), represent government performance on a wide variety of indicators. Specifically, government effectiveness, the closest proxy for bureaucratic/administrative power available, includes compiled survey and expert analyzed data on physical infrastructure, civil service delivery, the quality of civilian bureaucracy, corruption etc. ${ }^{12}$ Scoring ranges from -2.5 , representing the lowest levels of government effectiveness, to 2.5 , indicating the highest. As the data in Table 5 indicates, Burma features the lowest score among the Southeast Asian cases, which is representative of a long history of military rule, as a fully functioning civilian bureaucracy was never developed in the interest of diverting limited resources to the military itself. The highest levels of government effectiveness, comparatively, are found in Malaysia, Thailand, and Vietnam. While all three countries still rank below their OECD counterparts, they have been better able to craft a functioning bureaucracy than their neighbors in the region.

\footnotetext{
${ }^{12}$ For further information on measurement, see http://info.worldbank.org/governance/wgi/pdf/ge.pdf
} 
Table 5: Worldwide Governance Indicators

\begin{tabular}{|c|c|c|}
\hline Country (2017) & Government Effectiveness & Percentile Rank \\
\hline Burma & -1.05 & 13.46 \\
\hline Thailand & .38 & 66.8 \\
\hline Laos & -.35 & 38.4 \\
\hline Cambodia & -.65 & 25.48 \\
\hline Vietnam & .002 & 52.88 \\
\hline Malaysia & .83 & 76.44 \\
\hline
\end{tabular}


Figure 4: Government Effectiveness (1995-2017)

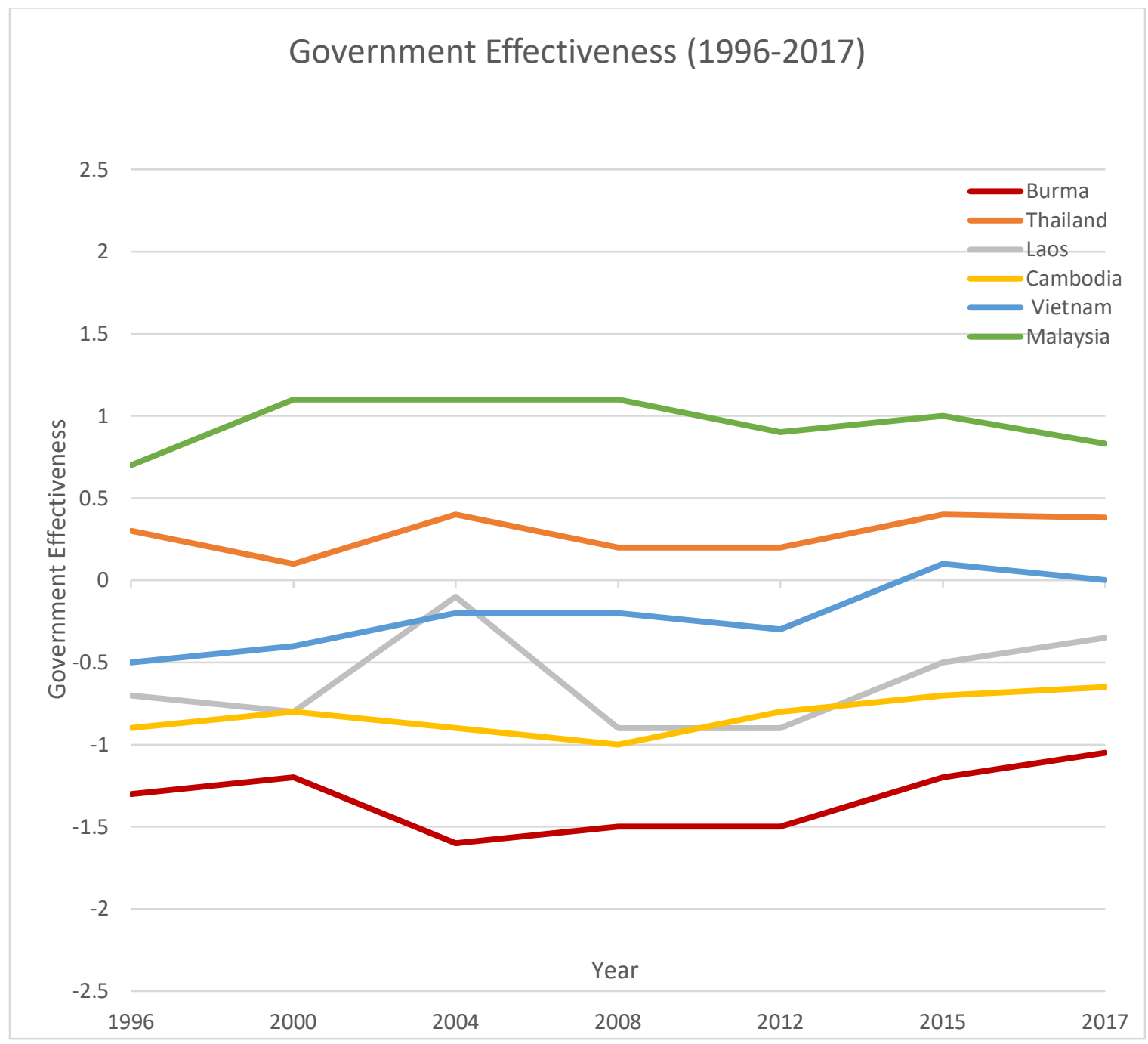

Finally, as a proxy for regime strategic imperatives toward religion, I have consulted data from the Association of Religious Data Archives. The "Government Regulation of Religion" values are aggregated from survey data which asks questions such as whether the government interferes with an individual's right to worship, and whether freedom of religion is generally protected. Here, 3 represents the highest level of government regulation of religion. The "Religious Minority Discrimination Index" refers 
to the number of people physically abused or displaced on a scale of $1-3$, with 3 representing the highest level of persecution.

\section{Table 6: Government Regulation of Religion}

\begin{tabular}{|l|l|l|}
\hline Country & $\begin{array}{l}\text { Government Regulation of } \\
\text { Religion Score }\end{array}$ & $\begin{array}{l}\text { Level of Minority } \\
\text { Religious Discrimination }\end{array}$ \\
\hline Burma & 3 & 3 \\
\hline Thailand & 3 & 2 \\
\hline Laos & 3 & 3 \\
\hline Cambodia & 2 & 1 \\
\hline Vietnam & 3 & 3 \\
\hline Malaysia & 3 & 3 \\
\hline
\end{tabular}

While the selected data in Table 6 provides a rough estimation of a given state's priorities vis a vis religion, it remains an imprecise measure that largely captures how regimes regulate religion broadly across society. In this sense, it does not narrow the scope of inquiry sufficiently enough to make claims about the specific methods used by regimes coopt or coerce specific religious organizations. The key takeaway from the data is that all regimes in the region, as of 2008 , do attempt to regulate religion and engage in some degree of religious persecution. The key exception appears to be Cambodia, which displays at least in this data, a remarkably low tendency to involve itself in the regulation of religion and persecution. Given snapshot data, this is likely an aberration which requires further investigation. As of 2015, the Cambodian regime has continued to actively sponsor Buddhist instruction in schools, while closing selected Vietnamese religious sites (Department of State 2015). In terms of government regulation and 
persecution, Burma ranks far higher than its neighbors, though this may also be attributed to a specific point in time. Here, 2008 data reflects the Saffron Revolution and accompanying government crackdowns against politically active Buddhist monks. For these reasons, qualitative case study research is important to contextualize and detect patterns in regime regulation of religion over time.

As suggested earlier, the preceding indicators are meant to serve as the best rough estimates for coercive and bureaucratic/administrative power across the region. Corresponding changes in values indicate that state power does change over time, but not dramatically. In other words, few would argue that Vietnam's large cuts in military spending and personnel during the 1990's are indicative of a more vulnerable regime. Conversely Burma's commitment to spending an outsized portion of its budget to the military has not made the regime any more durable. In truth, the regime was forced to make several important political concessions to avoid total collapse following the Saffron Revolution of 2008. What the coercive power indicators reveal are broad patterns that align with specific periods in state evolution and devolution. Historical case-study contextualization will put this data in its proper perspective.

By contrast, data assembled from the World Governance Indicators for bureaucratic/administrative power more directly approximates state functionality. Here, states like Cambodia, Laos, and Burma, who have a long history of low bureaucratic/administrative capacity are not able to easily escape damages wrought on the state from its very inception. A lack of bureaucratic/administrative power in the aforementioned states has two important causes, which will be further elaborated on in 
the relevant case-study chapters. Suffice it to say that all three states were considered peripheral by the French and British colonizers, receiving far fewer resources than the respective crown colonies of Vietnam and India. This problem was exacerbated by a long history of violent conflict, draining an already defunct civilian bureaucracy of its limited resources. Conversely, while Vietnam has a long history of violence commencing with its independence from France, it had a centuries long history of Chinese-style bureaucracy, which it reconstructed at the end of the Second Indochina War.

The next chapter takes a step back to extensively review theoretical literature in the interest of showing how I arrived at important theories and concepts. 


\section{LITERATURE REVIEW}

The subject matter under consideration requires the synthesis of diverse literatures on state capacity, authoritarianism, and civil society. All three of the aforementioned concepts are notoriously contentious and have been the subject of vigorous debates within the discipline. With respect to state capacity, certain scholars have argued that the state should have a central place in political analysis (Slater and Fenner 2011; Evans, Rueschmeyer, and Skocpol 1985), while others claim that the state itself is epiphenomenal and best understood as a collection of agents embedded within various institutions. Such reductionist theories, typified in neo-Marxist and political systems theories, see the state as a mere locus of competition for social actors. My own research is sympathetic to the first approach, as it understands the state as a historically constituted entity possessing its own reserves of power. As such, it is analytically distinct from other political structures, including its rules and practices (institutions) and the elites who govern through them (actors).

The following sections will elaborate further on the nature of the state and its interactive relationship with regimes and society. First, I embark on a discussion of four prominent approaches to state/society theorizing, namely the Weberian, Marxian, Political Systems, and Bellicist traditions. I will then explore the work of Michael Mann, and his intellectual heirs, as this research relies heavily on his specific sociological approach to understanding the state. I then move to discuss the structure and strategic imperatives particular to authoritarian regimes. The next section reviews and expands 
upon important literature on civil society and religious organizations operating within authoritarian contexts. The final section engages in a preliminary discussion of important relations between states, regimes and prominent religious organizations within six Southeast Asian countries: Burma, Thailand, Cambodia, Laos, Vietnam and Malaysia. Theorizing the State: Weberian, Marxian, Political Systems, and Bellicist Approaches Max Weber (1919) famously defined the state as an entity that holds a monopoly on the legitimate use of violence within a given territory (Weber 1919). This neat and precise notion of the state transgresses disciplinary boundaries, persisting as the definition with which all students of state capacity are forced to grapple. For Weber, the modern state is characterized not only by its ability to employ force, but also its reliance on legal-rational authority; which at base requires the presence of a bureaucracy capable of internalizing and implementing a given state's chosen policies. Weber differentiates between the legal-rational state as his ideal-type, and two other forms of authority, namely, the traditional and charismatic (Weber 1958). The latter two, he argues, are almost always found in those less-developed societies that have not yet evolved beyond the politics of personalist rule.

In tracing the historical development of the state, Weber assumes a teleological process whereby more primitive society eventually evolves toward the legal-rational ideal type. As a grand theory, Weber's tendency to explain a universe of political outcomes from a specific historical process in Western Europe creates both conceptual and methodological issues, as he, in part, conceives of a powerful state in territorial terms. In reality, state capacity varies widely, as it is a product of historical events particular to the 
state in question. In much of the developing world, post-colonial regimes have been tasked with building their state from near scratch, leading to the uneven development of agencies and bureaucracies within particular states. Weber's neat characterization of the state has been praised for its theoretical elegance, but also criticized for its oversimplified, technocratic approach to state/society relations. Evans, Reuschmeyer and Skocpol conclude that Weber's strong bureaucratic state implicitly assumes a negative relationship between state and social power. In other words, as the strength of the bureaucratic state increases, society must lose its ability to contest the state (Evans, Rueschmeyer, Skocpol 1985, 353). In this respect, Weber fails to gauge the myriad ways in which a powerful state can embed itself within society.

Neo-Weberian scholars (Skocpol 1979; Evans 2012; Mann 1986) have maintained a commitment to analytically separating the state from its constituent actors. Here the basic assumption is that the state can and should be imagined as an entity conceptually distinct from political and economic society. For Weber, as alluded to before, the state contains the three elements of territoriality, violence, and legitimacy. Of these constituent parts, it is most evident that no state as an entity can fundamentally exist without maintaining some control over territory, even if the degree of control varies across cases. The two other features, violence and legitimacy, become conceptually problematic if one is to maintain a commitment to keeping regimes and states analytically distinct from one another. In other words, can a state actually wield violence, or should we properly attribute that ability to the regime that has access to state resources? In a related sense, legitimacy also seems to be under the purview of a regime, as a state itself can merely exist, persist, or collapse, regardless of whether it is considered legitimate. 
Most useful to draw from the Weberian and corresponding Neo-Weberian perspectives is the insight that the state does in fact occupy a separate conceptual and analytical category. The particular features of the state/regime nexus will be more closely examined in later sections.

Any discussion of state/society theorizing would be grossly inadequate without addressing influential and enduring Marxian approaches. This research tradition, though too diverse to discuss at length in this project, begins with the simple proposition that the state itself exists as an entity explicitly designed to serve the interests of dominant social class. More specifically, elites use the state's bureaucratic agencies to extract revenue from the proletariat more efficiently, while state coercive power intends to keep the masses from revolt. For classical Marxists, the state's approach to its own citizens and those in the developing world is essentially the same; economic extraction and social dominance are the proximate goals of the bourgeois class.

Neo-Marxist and Critical Theory accounts, more astutely aware of the pitfalls of economic determinism, assume that the state first and foremost serves as an important venue for the dissemination of bourgeois ideology. Through formal education, corporaterun media, and minority scapegoating, elites within the state attempt to shape public preferences as a means of exerting greater social control (Edelman 1988). Marxist accounts, though ideologically persuasive, do struggle to explain deviant cases, specifically where the state rules against the interests of the dominant class. Neo-Marxist research on welfare states suggests that the state is capable, at least in some instances, of 
breaking with the mandates of the dominant social class (Poulantzas 1974; Miliband 1969; Offe 1972).

Political systems theory reached its apex in the 1950's and 60's chiefly through the labor of David Easton. It reflected an era where political scientists began to vigorously apply insights from sociology in the interest of explaining how state and society co-exist in a complex web of interaction. Easton's own work was partially derived by renowned sociologist Talcott Parsons' division of the social system into four main subtypes, namely, the economic, political, cultural and social. The structural patterns of interaction between these subtypes in turn defined the character of the overall social system. (Easton 1981, 320). In Easton's account, the state truly serves as a venue for processing the demands of citizens, or "inputs", and in return delivers specific laws and policies, or "outputs". Yet, more than effective policy delivery is required for a political system to endure. The latter is also maintained by citizens' internal and external support for the system. External support is typical expressed in terms of voting in elections or supporting political candidates. Internal support pertains to the psychological orientation of citizens who have internalized the norms and values of a political system.

In terms of state conceptualization, Easton argues that no political system exists in a vacuum but is rather embedded in a much larger matrix. He writes, "the way in which a system works will be in part a function of its response to the total social, biological, and physical environment” (Easton 1957, 384). While Easton does differentiate the political system from other systems in society, he can be rightly critiqued for committing a naturalistic fallacy, whereby he adopts observations from the natural 
world and correspondingly applies them to the political realm. As such, politics is imagined as an organic entity where inputs and outputs create a functioning feedback loop. Here, the state is not conceptually distinct from society, but rather functions as a sort of transmission belt that channels citizen demands into policy outputs. In terms of its overall contribution, political systems theory casts a deliberately broad net, attempting to explain politics at both the macro and micro levels of analysis.

Bellicist accounts of the state, featured prominently in the work of Charles Tilly, and others understand the historical development of the state in western Europe as a consequence of near continuous war-making between hostile kingdoms and principalities (Kisangani and Pickering 2014; Stubbs 1999; Kiser 2001). To maintain parity with their neighbors, royals had to find effective ways of extracting revenue from their subjects (Tilly 1975). In turn, bureaucracies were expanded to fund costly war-efforts; resulting in stronger states, but also societies which came to demand more from their rulers. Prominently featured in the Bellicist accounts are notions regarding the importance of territoriality. In terms of the state's power, the ability for elites to capture land and subjects was intimately linked to whether it could subdue challengers. Modern territorial conceptions of state power, while straightforward enough, must differentiate between territory under formal control and that which is merely claimed by a given state. While this is less of a problem in the contemporary western context, the global south features a plethora of states who legally possess, but do not effectively govern said territory. Somalia and Afghanistan serve as two of the more extreme examples of this phenomenon. While analytically useful, territorial control is not of central interest to this 
project, as I focus primarily on religious organizations already operating under the actual authority of the state.

In terms of applying the Bellicist account to the contemporary Southeast Asian context, Mary Callahan (2003) discusses how continual war-making led to the uneven modernization of the Burmese state. During the civil war of the 1950's, the Burmese military, faced with challenges from both domestic enemies and the invading Chinese Kuomintang army, siphoned off resources from non-military institutions and developed “a coercion-intensive” state (Callahan 2003, 222). In a similar vein, Ong Weichong's book (2015) Malaysia's Defeat of Armed Communism traces the evolution of the modern Malaysian state, arguing that low intensity conflict during the anti-communist "Emergency" period strengthened the military and civilian bureaucracy, expanding rule into previously untouched geographic territory (Ong 2015, 149). In both cases, internal conflict provided authoritarian regimes with the incentives necessary to engage in a certain type of state-building. A key difference, of course, is the degree to which the development of the bureaucracy evolved in both states. The Malaysian regime's decision to strengthen its civilian bureaucracy, marks a direct contrast to Burma's deliberate weakening of those same institutions; a dynamic which will be discussed in greater detail in the corresponding case study chapters.

Michael Mann’s (1984), seminal article "The Autonomous Power of the State", though couched in the Neo-Weberian tradition, takes a slightly different approach to state theorizing than his predecessors. Rather than operating from the assumption that all states feature elements of legitimacy, territoriality, and violence, he instead argues that states 
are defined by their reserves of infrastructural and despotic power. The former pertains to a state's ability to penetrate society through an effective bureaucratic apparatus (Mann 1984, 118). In the simplest terms, despotic power is the degree to which governing elites can use the state to impose their will over the rest of society. In states with high despotic power, there are few constraints on the use of force against citizens (Ibid, 113) ${ }^{13}$. More specifically, policies that the state's elites devise to control its citizenry requires virtually no consultation with the mass public. In tracing the history of state development, Mann argues that pre-modern empires were particularly high in despotic power, but weak in infrastructural power, since kings and emperors could typically impose their will on their own subjects with little consultation. It was the long process of economic modernization and technological development that eventually enhanced the infrastructural power of most modern states.

Mann argues that contemporary democracies tend to be very high in infrastructural power, but low in despotic power because elites operating in democratic regimes cannot merely impose their will on citizens without facing backlash from masses and rival elites. With respect to civil society, Mann argues that despotic power is power over society, while the second pertains to the state's ability to "coordinate and penetrate the activities of civil society through its own infrastructure" (Ibid, 190). Mann adds that

\footnotetext{
${ }^{13}$ Despotic power is most effectively deployed against weak societies that lack the organizational capacity necessary to challenge the ruling elite. These societies can, in turn, be made and kept weak through intentional regime strategies. A robust civil society, by contrast, is better equipped to check a state's use of despotic power.
} 
the state contains economic, military, and ideological elements, which are combined in various ways to enhance its power both over and through society (Ibid, 193). ${ }^{14}$

Mann's own concepts are situated in an exploration of long-term state formation processes, this is particularly evident in his distinction between European feudal systems, which were high in despotic power and low in infrastructural power, and contemporary European democracies where the opposite holds true. As an evolutionary account of state development, Mann convincingly writes how variation in state capacity is linked to longer-term processes of democratization in the western context. Unfortunately, Mann's concepts, while important in their disaggregation of different forms of state power, do not lend themselves to neat operationalization. It is difficult in practice to untangle Mann's definition of despotic power as the state's unhindered ability to impose its will on its subjects from a competing concept, state autonomy. Furthermore, for Mann, despotic power is applied most readily to the policy-making realm. States high in despotic power can make certain policy decisions with minimal consultation from outside groups. Yet, it remains a bit unclear whether this freedom is expressed solely in the application of physical force, or in other policy areas as well.

In terms of Mann's other important concept, infrastructural power, there is a related danger in operationalizing a term that may connote something else altogether. For example, infrastructural power, in Mann's imagination, does not pertain to the development of roads, ports, or bridges, but more closely resembles the strength of the

\footnotetext{
${ }^{14}$ While the economic and military dimensions of state power are of particular importance for this research, the ideological aspects of state power will be discussed in brief.
} 
bureaucracy. In this sense, it is advisable for operationalization purposes to stick with a simpler, more direct concept, namely bureaucratic/administrative capacity. Hendrix (2010), cites bureaucratic/administrative power in terms of bureaucratic quality done through survey methodology, as well as measurements of risk. Fortin (2010), sees bureaucratic/administrative capacity as closely related to measures of corruption or good governance. The most useful way of gauging bureaucratic/administrative capacity is evident in the work of Cardenas (2010), who measures the effectiveness of the bureaucracy in delivering goods and services, along with Knutsen's (2012) reliance on the bureaucratic quality index.

In line with Mann's exercise in disaggregating state power, Hanson and Sigman (2013) make further distinctions between a state's coercive capacity, administrative capacity, and extractive capacity (Hanson and Sigman, 2013). Coercive capacity is judged in Weberian terms, as a state's ability to maintain a monopoly over the use of force in a given territory. Thus, states incapable of eliminating insurgencies, or enforcing control over their borders likely have low state capacity. Administrative capacity is the state's ability to develop policy and deliver goods and services across a territory effectively. In a modern state, these sorts of goals require a competent bureaucracy. Finally, extractive capacity pertains to a state's ability to collect revenue from its citizens. Like administrative capacity, extractive capacity requires an efficient bureaucratic apparatus. This tri-partite distinction is conceptually useful but contains a host of potential measurement problems. In brief, it is difficult in practice to disentangle administrative capacity from extractive capacity. Furthermore, tax revenue collection is notoriously difficult to measure, particularly in the developing world. A given regime 
may have the ability to collect more tax, but for political reasons chooses not to do so. Furthermore, tax collection relies on administrative capacity, and at least the assumed threat of coercive action if the law is disregarded.

\section{State Capacity or State Autonomy?}

State power does not simply pertain to a state's endowment of resources, but also the regime's ability to actualize their policy goals throughout the state with minimal constraints. This follows Peter Evans' important distinction between state autonomy and capacity (Evans, 1995), an inherently challenging conceptual debate which has confounded many students of state capacity. ${ }^{15}$ Soiter and Hau write, "The extent of the state's freedom from social constraints on policy choice is shaped largely by its autonomy from societal actors, or the extent to which state leaders can enact their own preferences into policy" (Soiter and Hau 2008, 224). The same distinction also holds true for a state's reserves of infrastructural power. It is not enough for a given state to merely possess bureaucratic/administrative institutions, instead, they must have actors capable of enacting chosen policies ${ }^{16}$. A state with robust infrastructural power features agencies that regularly coordinate their actions, both horizontally and vertically.

The degree to which the state is autonomous from society is the subject of intense debate within the political science and public policy disciplines. Phillippe Schmitter (1985), argues that the modern state is "amorphous" with very poorly defined boundaries

\footnotetext{
${ }^{15}$ For a review and critique of state autonomy as a concept see Seabrooke, Leonard. 2002. "Bringing Legitimacy Back in to neo-Weberian State Theory and International Relations." Working Paper: Australian National University

${ }^{16}$ Barbara Geddes (1996) refers to this as implementation capacity. See Geddes, Barbara. 1994. Politician's Dilemma: Building State Capacity in Latin America. University of California Press.
} 
(Schmitter 1985,33). This sort of description, while superficially convincing, does not address the broader question of what state autonomy is, and how it might lend itself to empirical measurement. At the very least, the aforementioned concept implies that the political elite possess a certain degree of control over the creation and implementation of public policy. State autonomy readily conjures up the image of a leadership cadre capable of imposing their will over society, bearing a striking resemblance to Mann's notion of despotic power.

Yet, it is also not completely evident that state autonomy and power are synonymous. Strong states may not be particularly autonomous, preeminent among these are the consolidated democracies of the West. In the United States, a decentralized political system with institutions designed for both direct and indirect citizen participation, significantly limits the autonomy of the ruling elite. Even within autocratic systems, the regime may rely heavily on support from certain segments of the population. The patronage of labor organizations or ethnic groups involves the distribution of state resources, which in turn changes the future expectations of the regime and patrons alike. The sorts of formal or informal contractual relationships an autocratic state crafts with select members of civil society limits its autonomy.

In this spirit, Evans, Reuschmeyer, and Skocpol (1985) argue that any conceptualization of the state should be imagined in terms of a spectrum. Strong states can either gain or lose autonomy over time. Autocratic states eager to implement market reforms often lose a degree of autonomy over their affairs to an emerging economic society eager to translate their new wealth into political power (Evans, Reuschmeyer, 
Skocpol 1985, 354). Like capacity, autonomy within states can vary as well. As structures of the state change over time, regime officials may have to alter their relationships with important members of society (Ibid, 14). The degree to which the former autocracies of Northeast Asia deliberately sacrificed autonomy in exchange for developing a more dynamic and open economic system in instructive of this phenomenon.

In moving away from fraught conceptual debate over the nature of the state, several scholars have broadened their research agenda in an attempt to answer the allimportant question, "state capacity for what"? (Cingolani 2013, 28) In other words, how and why do elites use state resources to attain specific goals? Related, as every state is a product of a long historical process, how do the actions taken by previous rulers shape the range of incentives and policy choices available to contemporary regimes? While regimes can work to enhance or diminish certain areas of the state, long-term institutional and cultural patterns often preclude the development of a rational bureaucratic/administrative state.

\section{State Capacity as Explanation and Outcome}

A new generation of scholars, emerging from Political Science, Economics, and Public Policy have moved beyond the conceptualization debate, employing different variants of state capacity as both explanatory and dependent variables. Acemoglu, Ticchi, and Vindigni (2011) testing the effects of patronage politics on state weakness, find a positive and reinforcing relationship between the two variables. Specifically, rent-seeking behavior among elites makes bureaucracies less efficient. This is readily evident in terms 
of a state's extractive capacity in cases where amount of tax which could be collected from society's wealthiest members is compromised in the interest of political expediency. While this study addresses how a given state's bureaucratic power is weakened through rent-seeking behavior, it is often the case that extracted rent is siphoned to reinforce the state's coercive apparatuses. The presence of strong militaries in states with otherwise weak civilian bureaucracies across much of Africa and Southeast Asia, demonstrates why state capacity should not be thought of in monolithic terms. In other words, casually employing the terms "weak", "strong", or "failed" to describe states is a useful heuristic, but still an overgeneralization that ignores powerful variance within and among different state apparatuses.

In their study of the effects of democratization on state capacity, Back and Hadenius (2008) find that the administrative state is strongest once a full democratic transition is completed. The authors find that this relationship is robust for the specific relationship between democracy and administrative capacity. Conversely, states in political transition, who are often in the process of shedding or redesigning old institutions, tend to lose a degree of administrative capacity, at least in the short term (Back and Hadenius, 2008). In reversing the causal arrow, Linz and Stepan (1996) argue that a certain degree of "stateness" is necessary for a democratic transition to take place. Specifically, the state must be able to maintain a Weberian monopoly over the use of legitimate force, combined with a bureaucracy able to "command, to regulate, and to extract tax revenues" (Linz and Stepan 1996, 21). 
State capacity has also been used as means of explaining specific political outcomes ranging from economic development to the outbreak of civil war. In terms of the latter, Fearon and Laitin (2003) have put forth the argument that weak states create conditions favorable for the development of rebel groups. Typically lacking territorial control and the ability to effectively channel political discontent through legitimate institutions, weak states appear to be at a higher risk for civil war (Fearon and Laitin, 2003: Hendrix 2010). In a similar spirit, through the lens of a rational-choice perspective, Neil Englehart (2009) argues that weak states are hostage to a fundamental principal-agent problem, whereby the military, police, and civil servants lack the resources to prevent and punish bad behavior on the part of their employees (Englehart $2009,164)$. In such a scenario, undisciplined agents of the state may commit human rights violations simply because the opportunity to engage in illegal behavior comes with minimal fear of official reprisal. In the application of his theory to the Burma case, Englehart argues that regime change alone is not sufficient to overcome decades of statebureaucratic decay. In calling for a policy of engagement, Englehart argues that state decay has magnified the principal-agent problem, as incentives for civil servants to supplement their income with illegal activity has risen over time (Englehart 2005, 635).

In explaining the effects of state capacity on long-term economic development, economists have argued that the states more capable of bureaucratic centralization have enjoyed greater prosperity. In the case of Western Europe, the centralization of fiscal revenue collection greatly expanded the reach of the state. In a study of the different development trajectories of north and south Vietnam, Dell, Lane, and Querbin (2015) argue that North Vietnam's proximity to China led to its adoption of a Confucian-style 
bureaucracy better capable of regulating citizens, while South Vietnam's economy, like its neighbors in Cambodia was shaped by long-term patron-client relationships which in turn inhibited the growth of centralized state authority (Dell, Lane, and Querebin 2015).

Due in large part to the extensive labor put forth neo-Weberian scholars, there seems to be a broad consensus that state and society are both conceptually and analytically distinct. In a deliberate step away from foundational theoretical questions, newer scholarship builds upon the assumption that states can and do operate in some sort of relative autonomy from society. Virtually all scholars of state capacity implicitly or explicitly rely on Max Weber's most basic claim that the state must have some sort of monopoly on violence and a degree of administrative capacity to carry out selected policies. Beyond this general agreement, definitions of state capacity vary widely. In tracing the definition of the state among top scholars since 1968, Andersen, Moller, and Skaaning (2014) find that all but two of the twenty scholars analyzed use the monopoly of violence as an important component of state capacity. Similarly, 15 out of the twenty aforementioned scholars also include some form of administrative effectiveness in their definitions (Andersen, Moller, and Skaaning 2014, 1206). Consequently, newer contributions to the state capacity literature either applies traditional concepts to new cases or introduces brand new dimensions of capacity for analysis.

While some of the new theoretical insights have been welcome, others have magnified the problem of conceptual proliferation and overlap, further complicating the art of state-society theorizing ${ }^{17}$. There is also a related concern that state capacity as

${ }^{17}$ In "The State of State Capacity": A review of concepts, evidence, and measures", Cinglioni identifies at 
explanatory concept too easily drifts into tautological reasoning, whereby strong state bureaucracies or strong militaries are said to be a product of high state capacity. The best way to avoid this pitfall is by maintaining clarity and transparency about conceptualization and measurement, while limiting the scope of inquiry so that state capacity is not employed as a catch-all explanation.

\section{State Capacity and Authoritarian Regimes}

In the all-important interest of creating conceptual clarity between states and regimes, it is important to caution scholars to not attribute behavior to states, but rather to the regimes that run them. In a nod to well-established sociological insights, Mazzuca (2017) argues that it is important to make a distinction between actors, and the structures that influence their behavior. He writes, "A serious theoretical loss occurs when the state is inadvertently used as a synonym of the government or administrative staff" (Mazzuca $2017,29)$. In this sense, it is the state that exercises power, but rather the elites who command state resources in the pursuit of select policies. When we discuss state action, we are really discussing government action (Ibid, 28). In the same spirit, it is important to emphasize an important conceptual difference between a state and regime. Robert Fishman (1990) has defined a regime as "the formal and informal organization of the center of political power, and of its relations with broader society". More plainly, a political regime consists of rules which determine who has access to power, and who

\footnotetext{
least seven dimensions of state capacity, including a) coercive/military b) fiscal c) administrative/implementation d) transformative/industrializing e) relational/territorial coverage f) legal g) political.
} 
does not. Conversely, a state, is a more permanent structure which contains both coercive and administrative elements (Fishman 1990, 428).

In practice, autocratic and democratic regimes face different sorts of constraints, even when endowed with similar state capacities. This is especially true when analyzing a given regime's stock of despotic power. While a democratic regime's state apparatus may feature a large amount of coercive resources, its ability to impose its will over society is frequently limited by rule of law, competing elites, and the strength of civil society. Conversely, while a hypothetical autocracy may possess a smaller military or police force than a democratic regime, it likely faces fewer societal constraints on mobilizing those forces within its territory.

Slater and Fenner (2011) argue that every authoritarian regime reflects underlying state power. More importantly, they observe that regimes largely inherit states, and as such state capacity is not subject to large fluctuations over time. In "State Power and Staying Power," they write: "State apparatuses are typically inherited rather than originally constructed by the regimes that run them, particularly in the postcolonial world. A strong state is the best historical foundation for a durable authoritarian regime, not vice versa" (Slater and Fenner 2011, 6). With a strong state, regimes are better able to coerce rivals, extract revenue, register citizens, and cultivate dependence (Ibid, 19). While the first three features are seemingly self-evident, cultivating dependence pertains to the ways in which regimes distribute goods through centralized patronage systems. A regime that can efficiently deliver goods and services to targeted groups may be more capable of buying off its opposition. 
While regimes indeed inherit states, they are not completely powerless to shape or alter their apparatuses. Slater and Fenner also argue that regimes maintain a degree of control over the state and can deliberately strengthen or weaken a state over time, though only by a certain degree. In an analogy to the state, "Drivers may "soup" up their cars, but they rarely build them from scratch or convert them into something that dramatically outperforms the original model" (Ibid, 16). Those modern regimes that have made such dramatic improvements to their state bureaucracy are truly exceptional, and have built upon a foundation laid decades, if not centuries earlier.

The State and Authoritarian Regimes

The extensive literature on authoritarian regimes has much to say about the strategic decision making of dictators and loyal elites. Gandhi and Przeworski (2006) argue that authoritarian regimes, when under threat, not only make material concessions to their opposition, but can also make policy concessions. In this respect, authoritarian institutions are more than mere "window dressing", but instead serve as important channels for the distribution of various resources. Secondly, authoritarian regimes base coerce/cooptation strategies on the resources available for redistribution and the composition of the opposition. When dictators need greater cooperation, they will distribute more policy concessions but fewer rents. And, when the threat of rebellion is high, they make extensive policy concessions and redistribute more resources (Gandhi and Przeworski 2006, 2-4). Dictators are able to eliminate uncertainty in the delivery of these resources, since they do not need to rely on extensive deliberation in the legislature 
(ibid, 24). This is an important insight as the effective redistribution of resources may forestall an incipient rebellion.

In a separate contribution, Gandhi and Przeworsksi (2007) argue that the degree of institutionalization within an autocratic regime, in part, predicts its survival. In this case, authoritarian institutions become an arena for the redistribution of policy rents. In most autocracies, a dominant political party acts as the conduit for rent retribution. In a scenario where the regime perceives a threat to its power emanating from civil society, legislatures featuring a token opposition provide an essential "trench" against rebellion as recipients of rent (Gandhi and Przeowrski 2007, 1293).

Contemporary autocrats have become adept at using existing institutions as a means of maintaining control over society. Following the collapse of the Soviet Union, and advent of the democracy's so-called "third wave", many hard-autocratic systems embarked on democratic transition processes. In practice, this resulted in varying degrees of liberalization, including greater press and media freedom, and the institution of regular elections. Yet, as Andreas Schedler (2002) keenly observes, many regimes have frequently used elections as "instruments of autocracy" (Schedler 2002, 3). Under the conditions of "electoral authoritarianism", elections are minimally competitive in the sense that opposition parties are allowed to participate, but face significant intimidation, financial barriers, or media blackouts from the ruling party.

Ostensibly, the purpose of such a system is to provide a veneer of legitimacy for the autocratic regime, while effectively controlling political outcomes. Autocrats also attempt to control the consequences of elections by effectively block incoming politicians 
from having any control over important policy domains. Schedler (2002) refers to these as a "fencing off" strategy, whereby unelected autocrats continue to make decisions with little or no oversight from elected officials (Ibid, 42). Contemporary Burma, where the military reserves 25 percent of all legislative seats for itself and creates policies without civilian oversight likely serves as a prototypical example of the "fencing off" policy.

Milan Svolik (2012) keenly observes in his influential book, The Politics of Authoritarian Rule that authoritarian regimes face two major threats to their rule, problems of power-sharing and control. The former pertains to how said regimes manage conflicts among political rivals, while the latter is concerned with how these regimes counter threats from their subjects. Svolik argues that dictators design institutions in ways that minimize threats from internal and external challenges. Through parties, the legislature, and politburos a dictator can mobilize loyalists, monitor rivals, and more efficiently communicate with high ranking officials (Svolik 2012, 11-13). Svolik also sees cooptation and repression as complimentary authoritarian strategies. While cooptation may ultimately be less costly for a regime, most regimes do feature large coercive apparatuses. Svolik argues that cooptation is most effective when the perks of party membership and career advancement are open not just to traditional elites, but also the masses (Svolik, 2011). Targeted ideological recruitment of a specific subset of the population in order to protect the regime against its opposition is critical for survival (Ibid).

Gerschewski (2013) argues that legitimacy, repression, and co-optation stand as the three pillars of autocratic regimes. As such, regimes that can effectively link all three 
are the most likely to endure (Gerschewski 2013,14). Legitimation refers to the ways in which authoritarian regimes cultivate citizen support through both the dissemination of ideology and policy performance outputs. Repression refers to physical violence and less obvious forms of coercion such as surveillance and intimidation. Cooptation pertains to ways that the regime can link a group of actors to itself. It can be done by formal means, through democratic institutions like legislatures or parties, or informally through patron client relationships. In practice, cooptation provides a way for the regime to link itself to business and/or opposition political or military leadership through the distribution of material or policy incentives. In such a relationship, Gerschewski notes that it is important for an authoritarian regime to distribute resources in such a way that not one single actor becomes too powerful, surreptitiously posing a new threat to the state (Ibid, 22).

Even when a state is able to create a powerful unifying ideology, that by itself, is not sufficient to explain regime survival. Cooptation, though an important strategic imperative, is inevitably accompanied by the aforementioned risk of non-compliance. Repression is also important weapon in the authoritarian arsenal, and the one most typically associated with authoritarianism, but alone cannot explain the longevity of authoritarian regimes. As a strategy, repression is a very dangerous strategy to maintain over time. By resorting to frequent crackdowns, the regime runs the risk of fractionalization within the military and eventual regime collapse (Lee 2014). Conversely, high levels of sustained economic performance can help ameliorate the authoritarian legitimacy problem. This line of reasoning is most frequently employed to explain the success and longevity of authoritarianism in Singapore. 
Repression alone also fails to resolve what Ronald Wintrobe $(1990,1998)$ has termed the "dictator's dilemma". In short, the more a dictator resorts to crackdowns, the more uncertain he becomes of his support base as citizens become more reluctant to voice their political preference. As this process unfolds, a dictator may begin to fear his own people, uncertain of whether certain groups are plotting rebellion. Wintrobe (2007) argues that a strategy of cooptation becomes necessary, as means of ensuring the loyalty of those who are in the best position to end his reign (Wintrobe 2007, 367). This sort of scenario, where dictators are forced to bribe citizens in exchange for loyalty, may lead to a whole host of unintended consequences. First, there is the very real possibility that the objects of cooptation may take the bribe, and then renege on their end of the deal. It is for this reason that the most effective authoritarian regimes do not rely solely on one particular strategy.

The existing literature on authoritarianism posits that a regime can engage in cooptation not just through financial reward systems, but also policy redistribution schemes. Acemoglu and Robinson (2000) argue that the extension of suffrage to a broader subset of the population, may serve as one such cooptation mechanism to forestall revolution, even if such a policy could lead to the regime being voted out of office. Cooptation can also be reflected in policies that open up new economic opportunities for a specific class of citizens. Bertocchi and Spagat (2001) argue that market liberalization in East Asia and post-Soviet Russia are two pertinent examples of authoritarian cooptation, whereby the former created new economic opportunities for the middle class, while the latter implemented laissez faire policies designed to appease powerful industrial leaders (Bertocchi and Spagat 2001, 28). 
While the aforementioned authors focus on regime strategy, they do not problematize the state. Thus, in linking state capacity to authoritarian regime strategy, I aim to fill an important gap in the literature.

Finally, in the interest of legitimation, authoritarian regimes may also rely on the mobilization of symbolic power (Bourdieu 1991; Beetham 1991; Gentile 2006), though this is not always amenable to empirical measurement, and as such does not occupy a central place in my proposed analysis. While symbolic power can be expressed through official regime ideology, it can also take subtler forms. Utilizing deeply embedded cultural symbols, a given regime may attempt to garner legitimacy without resorting to violence. The above description does imply an instrumental account of power, where elites deliberately channel symbolic resources with a purpose in mind. While there are certainly instances where elite actors unconsciously use symbols as a product of their own cultural socialization, it is likely that regimes mobilize symbols more aggressively when they feel vulnerable to rivals from inside or outside national borders. The role symbolic power plays in authoritarian regimes will become clearer in the case study chapters, though it is not featured in my theoretical framework.

\section{Civil Society}

The term civil society has been a conceptual grab-bag for scholars of comparative politics. In the western context, civil society typically refers to organizations that occupy a space outside the formal state apparatus. Non-for profits, fraternal organizations, and neighborhood associations all serve as clear examples of civil society entities. In one of the earliest attempts to define civil society, Hegel (1991) conceived of it as "a sphere of 
market relations, regulated by civil law, intervening between the family and state" (Hegel [1821] 1991, 220). In the $20^{\text {th }}$ century, the civil society debate has been defined by liberal and neo-Marxist approaches. While the former views civil society as a site for free political expression and preference formation, the latter conceives of it as an arena where counter-hegemonic discourse emerges to challenge elite prerogatives. This dissertation does not take a definitive ideological position on civil society, but rather adopts important insights from multiple research traditions in the interest of better understanding how authoritarian regimes attempt to coopt and coerce religious organizations (an important civil society actor) as a means on enhancing their own power.

The contemporary liberal civil society argument frequently centers on its hypothesized linkages to democracy. Proponents of this argument (Tocqueville, Almond, Putnam) argue that civil associations teach and re-enforce the social skills citizens need to actively participate in a democratic society. In turn, these thick webs of social interaction contribute to higher levels of vertical and horizontal trust. Detractors claim that the relationship between civic participation and democracy is not straightforward, and in fact, institutions over time can shape a culture favorable to liberal democracy (Acemoglu and Robinson 2012). This stands out as one important contribution of socalled neo-institutionalist scholarship.

Other scholars immersed in the civil society tradition have argued that the research program itself has a western bias, and as such its application to the developing world marks it as an evolving research agenda (Alagappa 2004, 26). Instead of viewing civil society as an arena for political and economic exchange, as in the prominent 
Hegelian frame, Alagappa views it in terms of "space, site, and agency" (Ibid, 34). In this respect, civil society is not tied only to specific actors, but exists as a space where various individuals can enter and exit. It also a battlefield for cultural and ideological expression. where organizations in civil society have real decision-making power (Ibid).

For the purpose of this dissertation, it is important to keep in mind that civil society is not merely a feature of consolidated democracies. In most authoritarian states, the regime cannot fully penetrate society. In such an arrangement, civil society may not be robust but can still operate in those spaces not directly controlled by the state. As I will discuss later, authoritarian regimes are not able to fully curtail civil society, particularly in societies where much traditional power resides locally.

Much of the literature imagines civil society as an entity distinct and autonomous from the state itself. While this conceptualization helps explain state/society relations in the west, it provides scholars with little analytical leverage outside of that region. Newer research on civil society under authoritarian regimes posits that the relationship is complex, and layered through "networks of material transactions, personal connections, and organizational linkages" (Lewis, 2013, 326). Edwards and Foley (1998) imagines civil society in terms of process, negotiation, and a contested domain. In this sense, civil society is more than just an institutional arena (Edwards and Foley, 1998). In addition, newer contributions tend to reject the Neo-Tocquevillian assumption that robust civil society is linked to democratization. For example, the study of Islamic organizations in autocracies as potentially non-liberal civil society actors has become more common in the literature (Khatib 2013). 
Within authoritarian systems of governance, regimes make a conscious effort to marginalize political opposition. In response to regime coercion and cooptation, civil society activists may choose to work within the existing institutions, rather than create new organizations from scratch (Chua, 1995) Undoubtedly, this raises the question of whether or not civil society organizations can actually persuade an authoritarian regime to listen to its demands. Rigorous case-study analysis is required to determine when authoritarian regimes make meaningful policy concessions to civil society groups absent credible threats of rebellion.

Conceptualizing civil society under authoritarian regimes also requires making a distinction between state-sponsored civil society organizations, and those that exist outside the formal control of the state. Government organized non-government organizations (GONGO's) are often created by authoritarian regimes for the purpose of garnering domestic and international legitimacy. These organizations are typically enlisted with the purpose of providing social services outside the reach of the welfare state. They also act to co-opt new social actors under the umbrella of a large governmentcontrolled organization. While these organizations are structured differently in particular states, they are typically highly constrained in their ability to challenge regime authority. However, these types of corporatist arrangements can come back to haunt authoritarian regimes, as they provide individuals with the organizational tools to engage in opposition activities.

The autonomy of civil society organizations should be imagined as a continuum. Iris Young measures the strength of civil society organizations according to their capacity 
for self-organization and their discursive contributions to the public sphere (Young, 2000). In most authoritarian settings, civil society groups are given some degree of autonomy over internal decision-making processes, and service delivery. This marks a key distinction between authoritarian regimes and their totalitarian counterparts (Linz and Stepan, 1996). This separation invites a broader conversation regarding the power of the state. While authoritarian regimes vary in their coercive and bureaucratic administrative power, totalitarian regimes as a sine qua non of their very existence, must be highly capable of controlling their society in both material and ideological forms.

Civil society actors in the authoritarian context can also produce counterhegemonic discourses which are often met with a variety of repressive tactics. The government can enact legislation intended to halt the spread of anti-government discourse, including imprisonment of journalists and newspaper censorship. It can also respond by co-opting the public space, through the mobilization of symbols and state sanctioned cultural activities. In the Gramscian sense, the regime may attempt to create a hegemonic discourse intended to diffuse legitimacy throughout society. However, regime discourse is not always mobilized effectively, and is frequently subjected to challenges from civil society itself. The discursive relationship between the regime and civil society is particularly fascinating in states where religious and cultural groups possess a high degree of traditional authority. In such cases, the regime will often resort to co-opting the traditional symbols, while providing patronage in exchange for political cooperation.

Civil society should not be imagined as a panacea for state and market failures. Nor should it be seen as completely distinct and autonomous from these spheres. Social 
relations are characterized by complex patterns of interdependence, featuring relations of both material and symbolic power. This does not mean that scholars should cease making important conceptual distinctions among social actors. It does demand that civil society is understood in broader terms, incorporating religious and cultural organizations that may not fit certain definitions, but are nevertheless crucial and collective actors in particular societies.

The aforementioned considerations are particularly important in contexts where the line between the state and religion has been historically blurry. Kikue Hamayotsu (2008) correctly observes, "In contrast to the modern secularist assertion that the state and religion should be separate, Southeast Asian states-both colonial and post-colonialhave actively interfered with religion.” (Hamayotsu, 2008, 174). Alagappa (2004) agrees, "Limitation of civil society to voluntary associations, however, excludes other groups (based on religion, heredity, ethnicity, class, and other such features) that are not open to all citizens_-groups in which membership is by assent, rather than consent, and exit is not a real option" (Alagappa 2004, 34). This broader understanding of civil society is an important feature of my analysis, as it permits me to compare organized religious groups across the region. Any discussion of state/society relations in Southeast Asia would be woefully inadequate without considering the myriad ways in which religion has permeated this fluid relationship.

Comparative studies of religious organizations under autocratic regimes help scholars better understand the complex interactive relationship between religion, power, 
and legitimacy ${ }^{18}$. For the purposes of this research project, power is conceptualized in both material and symbolic terms. The material power of a given group is understood as large degree of control over internal rules, regulations, and practices as well as the capacity to recruit and appoint leaders with a small degree of state interference. Such a group would be able to proselytize and perform social services with little external meddling. The autonomy of such groups is always limited, based upon important factors such as the strength of the state, the strategic calculations of a particular regime via religious organizations, and the corresponding strategies adopted by religious elites.

In most authoritarian contexts, I conceive that the relationship between the regime and religious organizations is best understood as a tug of war, as the regime attempts to effectively control all potential challengers, while religious organizations push for greater autonomy. It is important to note that religious organizations, even when materially coopted, will still look for opportunities to subvert official rules. In practice, this might include the creation of formal or informal subsidiary organizations which are more difficult for the regime to identify and control. In addition, a religious organization may look to diversify its sources of funding to lessen dependence on the state. This strategy is particularly effective for religious groups that take an active role in humanitarian work and disaster relief.

If the material relationship between regimes and religious organizations can be imagined as a tug of war, then the symbolic relationship is something more akin to an intricate dance. The symbolic arena is characterized by maneuvers intended to capture

\footnotetext{
${ }^{18}$ For an exemplary work in this tradition see Hedman (2001)
} 
legitimacy and moral authority. Collins (1975) remarks, "There is a dramatic linkage between power and legitimacy. Indeed, existing evidence strongly suggests that power is often achieved precisely by establishing a ritual community based upon the assertion of moral ideas and symbols of reality" (Collins 1975, 384-385). Legitimacy then is not simply conferred through force but is imparted through symbolic discourse and ritual. It is important to recall that symbolic power can be asserted by the regime and religious organizations alike; national holidays, displays of military prowess, and civic education are all means by which the regime employs symbolic power. In contexts where the line between the state and religion is blurred, one can expect to see regimes claim religious authority as a means of garnering popular legitimacy. Symbolic power is not merely attained through the use of clever argument but must work on both the cognitive and emotional fields to be effective. Bourdieu (1991) writes, "What creates the power of words and slogans, a power capable of maintaining or subverting the social order, is the belief in the legitimacy of words and of those who utter them. And words alone cannot create this belief" (Bourdieu 1991, 170).

David Beetham, in his book The Legitimation of Power argues in a Gramscian vein that power is more than the capacity to impose ideas on subordinates. It is also attained through the ability to "structure common interests", and limit choices available to subjugated groups. Thus, power is not only attained through coercion, but also consent. (Beetham 1991, 108). While these insights are more amenable to class analysis, they do hold some currency in the research on authoritarian regimes. Specifically, it appears that a given regime's symbolic power can be conceptualized as both a resource and an instrument that will largely depend on historical considerations. For example, a regime 
which traces its rule back to a successful anti-colonial struggle may have a deeper well of symbolic power to draw from than a one which came to power through an unpopular coup. Similarly, a regime that relies heavily on coercive force against its citizens may sacrifice some of its symbolic power simply to remain in power.

In sum, regimes employ strategies aimed at maximizing their power, enhanced by the strengths and constrained by the weaknesses of state capacity. How do regimes attempt to co-opt/coerce members of civil society, and when do they succeed? Similarly, when do regimes miscalculate and instigate a popular uprising? Also, how do religious organizations use strategies intended to gain autonomy from a given regime, or actively challenge it? This power contest features both material and symbolic elements. With respect to the former, organizations possessing large sums of money, land, and access to foreign donors should be better equipped than their poorer counterparts to exercise relative autonomy from the state. Additionally, in cultures where religious organizations have a great deal of power, the symbolic battle between a regime and religious groups predictably centers on the question of legitimacy. Here, we expect both groups to mobilize religious speech, rituals, and other symbols targeted at other elites and the mass public. Though the central hypotheses featured in this research focus on material power, symbolic power features prominently in several of the case studies.

The patterns of interaction between the state and its religious organizations are highly contextual and constituted historically. In this vein, scholars have been reticent to draw broad generalizations, preferring to rely on single-country case studies. Regional specialists have largely focused on the effects of organized religion on regime change 
(Casanova 1996). However, there are some important general distinctions that should be made at the outset. As opposed to either Catholicism or Islam, which is universalist in mission, Buddhism in Southeast Asia tends to take on a very national character (McCargo 2004, 215). In this sense, the relationship between the role of religious adherents and political activity also tends to be ambiguous. As Buddhist scriptures and religious tradition have always operated within the context of a state (modern or pre-modern), there is no clear line of demarcation between the merits of active religious participation or alternatively, quietism (Walton 2017, 127-162). Similarly, since there is no transnational centralized authority in Buddhism as contrasted to Catholicism, political questions tend to be worked out on a case-to-case basis. While some Buddhists have maintained that participation in politics is a moral requisite, others have expressed their disdain for politics as an activity beneath their dignity. States, on the other hand, have a similarly awkward relationship with religious adherents. While courting Buddhism and its most prominent leaders is an important way of gaining legitimacy, there are numerous examples across Southeast Asia of political leaders seeking to "purify" monasteries from politically active monks, who by their very involvement in secular affairs, sully the prestige of the religion.

This research, in taking a comparative approach to the study of the relationship among states, regimes, and religious organizations focuses most of its attention on domestic politics within each of the case studies. This choice is intentional and is done in the interest of controlling for additional variation in the variables which would almost certainly result from a more serious consideration of the international context. An abundant literature within the field of international relations researches civil society 
organizations (religious and otherwise) as important transnational actors. Prominent among this work is Finnemore and Sikkink's (1998) work on international norm diffusion (Finnemore and Sikkink 1998). Additionally, Samuel Huntington's (1991) research on the role of the Catholic Church in the third wave of democracy is also instructive of how religion as a transnational actor affect certain political outcomes (Huntington 1991). Within the Southeast Asian context, there is also important work concerning the ways in which transnational meditation movements shape the political behavior of Buddhist monks (Jordt 2007).

States, Regimes, and Religious Organizations in Southeast Asia

Perhaps unsurprisingly, the contemporary relationship between state and sangha varies across Southeast Asia. This is due in large part to different historical experiences with nation-building across the region. While a full discussion of the effects of modernization on Southeast Asian politics is well beyond the scope of this study, it is important to briefly explain how state/society relations were shaped by different colonial experiences. In Burma, nationalist movements in the early $20^{\text {th }}$ century were infused with Buddhist themes, and were at times even led by Buddhist clergy. The most historically important of these movements, the 1920 Peasant Rebellion, was led by U Ottama, a highly respected monk. Widespread nationalist or Thakin movements in the 1930's, were organized by groups like the YMBA (Young Men's Buddhist Association) and were reflected in the post-independence leadership of Burma's first Prime Minister U Nu. Buddhist nationalism in Burma was inflamed by Britain's deliberate policy of undermining the Buddhist majority in favor of largely non- Buddhist hill tribes, a social 
and political dynamic that still informs the contemporary relationship between religion and politics in this country.

Thailand, as the only Southeast Asian country to escape colonization, had a slightly different experience with state development as compared with Burma, their immediate neighbor to the west. During the $20^{\text {th }}$ century Thailand went through a process of internal colonization whereby the monarchy in Bangkok expanded across the country bringing formally autonomous provinces under its rule. The historically close relationship between the Thai state and the sangha remained largely intact during the $20^{\text {th }}$ century, despite strong challenges from both the military and student led-groups during the 1970's. As no foreign power implemented policies designed to undermine the centuries old patron/client relationship between the state and sangha, Thailand, viewed by the west as an important bulwark against the spread of communism in the region, absorbed large numbers of American funds and military hardware during the cold war era, which the state, in part, used this foreign aid to modernize its coercive and civilian bureaucratic apparatuses.

Cambodia, Laos, and Vietnam, once collectively known as French Indochina, were subjected to different sorts of colonial policies than British Burma. Instead of attempting to undermine Buddhism, French officials in Indochina actively sponsored indigenous Buddhist institutions out of fear that any organizations independently organized by the French could be eventually used against the colonial power (Keyes 2013, 22-23). Despite this policy and perhaps in direct response to it, the challenge to French authority arrived through secular ideas and organizations. The arrival of Marxism 
in Indochina framed resistance to the colonists' in a well-developed ideological framework. Communist leaders were also more successful in recruiting members of the peasant class to their cause then in Burma. The Vietcong, Khmer Rouge and Pathet Lao were all expressions of Marxist ideology, albeit with very different strategic imperatives. Under the shadow of Marxist rule in Cambodia, Laos, and Vietnam, the state's response to organized Buddhism has been largely hostile. Yet, in these three cases, the ability of nominally Marxist regimes in eliminating threats emanating from organized religion differ. While the Khmer Rouge almost completely wiped organized Buddhism out of Cambodia, Vietnam has largely placed organized Buddhism under their control, while the government of Laos has historically been unable to control organized Buddhism.

While post-colonial Thai and Burmese Buddhism has historically played a legitimating role for the state, in Cambodia, Vietnam, and Laos Buddhism has been viewed by the Communist regimes as an obstacle to be surmounted. The Buddhist sangha under authoritarian regimes can play different roles, which Charles Keyes (2013) nicely frames as "Engaged or Enraged Buddhism" (Ibid, 24). Certain monks in southern Thailand embody the latter, as they have fought on behalf of the Thai state against a Muslim-Malay insurgency on the border. Similarly, enraged Buddhists in Burma under the name $\mathrm{Ma} \mathrm{Ba}$ Tha have sanctioned violence against Muslims and have pressured government officials to institute more restrictive laws designed to decrease Muslim birthrates. Conversely, other monks in Southeast Asia have played the role of Engaged Buddhists, promoting development activities in rural areas and inter-faith understanding. Of central concern in this project is the way that particular regimes have approached sangha leadership. 
In addition, regimes across Southeast Asia have employed a variety of tactics designed to marginalize or eliminate all political challenges emanating from organized Buddhism. Accordingly, some regimes have been more effective than others in achieving their goals. The task of this project is not to problematize a given regime's rationale for targeting Buddhism as an institution, but rather to explain how and why certain strategies were either successes or failures. In other words, the ideological or individual personality traits of given leaders must certainly play some role in explaining why particular strategies were chosen against others, however, these individual-level features alone cannot fully account for specific country-level outcomes. Instead, I hypothesize that the range of strategies available to regimes, and the ultimate consequences of their implementation are conditioned by the corresponding strength or weakness of the state.

Malaysia's own experience differs from the aforementioned states in that Islam is the dominant religion of citizenry. However, like Thailand and Burma, the state's own history is dominated by patronage of the majority religion. Malaysia's most dominant modern political party the United Malay National Organization, is Islamist in identity, and in part, derives much of its legitimacy from its support of the dominant religion. The strength of the Islamist ideology was buffered throughout a thirty-year period of low intensity warfare against a communist insurgency. In contrast to Burma and Thailand, Islam is the official religion of the Malaysian State, with other minority religious groups entitled to the free practice of their own faith. As the official state religion, the patronage of Islam has been perceived by elites as one of the state's official responsibilities. In the context of this research project, Malaysia, while clearly different from the majority Buddhist states in the region, also shares some important similarities that justify its 
inclusion in my comparative case study research. Specifically, the particular ways in which Malaysian political elites have managed their relationship with the religious majority, in a context where public religion has tremendous historical importance, resonates strongly with the other cases featured in this dissertation.

The preceding discussion provided a review of the most important and relevant literature in the areas of state capacity, authoritarian regime strategy, and civil society. Looking ahead, the following chapters will take a closer look at the complex relationship between the state, regimes, and religious organizations in southeast Asia and beyond. 


\section{BURMA}

This chapter traces the evolution of state/sangha relations in Burma from independence (1948) to the present. To best explain how successive military regimes have employed dual strategies of cooptation and coercion against the Burmese sangha, the following analysis is divided into five chronological sections. First, I will provide the reader with some essential historical background on the political role of organized religion during the late precolonial and colonial eras. The second section addresses state/sangha relations under Burma's first post-independence parliamentary government (1948-1962), while the third analyzes this relationship under Ne Win's Burmese Socialist Program Party (BSPP) (1962-1988). The fourth part of this chapter shifts attention to various strategies employed by various post-Win military junta leaders (1988-2015), while the concluding section examines treatment of the sangha under the current hybrid regime (2015-present).

At the outset, it is important to briefly summarize the historical role of the sangha in Burma. First, in terms of organization, the sangha is only formally hierarchical ${ }^{19}$. While monks are registered and supervised by the state's Ministry of Home and Religious Affairs, most monks operate independently. In truth, it is almost impossible for the government to keep track of all sangha activities, as many monks only take up temporary vocations. Joining a monastery may be viewed by the novice as a form of merit-making or a rite of passage, rather than a lifetime commitment (Walton and

\footnotetext{
${ }^{19}$ For more details regarding the contemporary structure of the Burmese sangha, see Kawanami (2013)
} 
Jerryson 2016, 12). As was the norm in the precolonial era, the contemporary monastic setting provides an opportunity for young men to pursue their education, and thus may serve as a springboard for professional advancement. Additionally, even larger monastic organizations tend to be fluid and temporary, thus further complicating the problem of identifying politically-active monks (Spencer 1954, 73).

Secondly, in Burma, as is the case in other Theravada Buddhist societies, there is no clear demarcation between religious and political activities. While monks are officially prohibited from participating in politics in accordance with the monastic code of conduct (vinaya), this matter is largely up to individual interpretation. For some monks, this might mean avoiding anything which might be labeled as political, while others may interpret the rule to prohibit the pursuit of a career in organized politics (Walton 2015, 512). While monastic rule deems political involvement as an activity beneath a monk's dignity, all monks are encouraged to act when the Buddhist religion comes under threat (Ibid). What constitutes a threat is also highly subjective, as some nationalist monks within groups like Ma Ba Tha and "969" have argued that Muslims, particularly in the western part of the country, poses an existential threat to Burmese Buddhism $^{20}$.

Finally, it should be noted that the actual number of monks participating in political activities, though impossible to accurately gauge at any given time, remains small compared to the overall size of Burma's sangha (Ibid, 510). Whether this is a matter of personal preference or fear from the real possibility of government reprisal

\footnotetext{
${ }^{20}$ See Walton and Hayward (2014)
} 
remains an open question. Notwithstanding the sizable number of monks who do not participate in political activity, Burma's sangha, in regional terms, is indeed remarkable in terms of the role it has played in anti-government activities dating back to the colonial era. The following analysis demonstrates that this dynamic occurs not because of a difference in Buddhist ideology or practice in Burma, as compared with other Theravada Buddhist countries in the region, but because the Burmese state apparatus, despite the best efforts of successive regimes, has lacked both the coercive and bureaucratic/administrative power required to keep Buddhist monks loyal to the regime.

\section{State/Sangha Relations in Pre-Colonial Burma}

Perhaps the most significant and enduring feature of the $18^{\text {th }}$ century in Burma was the premodern state's inability to establish a Weberian monopoly of legitimate violence over large swaths of territory. The combination of topographical features like dense jungles and impassable mountain ranges, coupled with low-population density, contributed to what Owen has identified as the emergence of Southeast Asia's "contest states". In this arrangement, monarchs often claimed to wield universal power, though frequent challenges to their authority from regional and village headmen circumscribed this royal influence $($ Owen 2005,54$)$. In fact, the obstacles to rule were so pronounced in mainland Southeast Asia, that most royals had to rely on informal bargaining networks just to keep subjects within their kingdoms (Ibid, 55). This royal predicament was certainly evident in $18^{\text {th }}$ century Burma, where subjects frequently fled the state for the hill kingdoms as a means of escaping royal service (Ibid, 63). Consequently, Burmese 
kings frequently had to rely upon mercenaries and captured slaves to supplement their armies.

Burma's Toungoo (1510-1752) and Konbaung (1752-1885) dynasties were materially sustained through tributes paid by local headmen and symbolically through their relationship with the Burmese sangha. For much of the precolonial era, the sangha was exempt from taxation, thus contributing to what Norman G. Owen has described as an alternative locus of power operating outside of royal control (Ibid, 86). This did not stop certain monarchs from patronizing favored monastic sects, which in turn, antagonized other less politically influential members of the sangha (Ibid). Though not always making explicit appeals to divine right like their European counterparts, Burmese monarchs and subjects alike believed that kingly authority stemmed from karmic merit accrued through previous reincarnations. In exchange, the king was expected to act in concert with Buddhist values, often prominently displayed through sangha patronage. Juliane Schober (1995) describes patterns of interdependence between religious and political authority in traditional Buddhist societies as a "pre-modern totalizing construct in which social, religious, and cosmological orders were integrally linked" (Schober 1995, 309). In this respect, the political did not emerge as a realm functionally distinct from the religious or cosmological until the arrival of the British in the $19^{\text {th }}$ century.

Despite royal pretense to the contrary, the idealized condition of quid pro quo relations between state and sangha, identified in the Theravada tradition as the "two 
wheels of the dhamma" 21 , rarely operated smoothly. Court realpolitik coupled with sectarian disputes among monastic leadership created a system of political insiders and outsiders. The history of "state monks", a derisive term frequently employed to describe politically-engaged monks in post-independence Burma, can be traced back to at least the $19^{\text {th }}$ century, as King Mindon, Burma's penultimate monarch, established his Thudhamma council ${ }^{22}$ as a means of exerting greater control over the sangha. E. Michael Mendelson writes, "The story of Mindon's championship of the Shwegyin Sayadaw ${ }^{23}$ also suggests that his policy may have well have been to play off various monks on his council against each other, and to use the Thathanabaing' ${ }^{24}$ position to create antagonism among the great monks of the time, who as noted above, were part of a small oligarchy of masters, disciples, and friends" (Mendelson 1975, 102). The precolonial practice of cultivating loyalty among influential monks, an important feature of royal politics, was permanently altered by the British colonial administration, which actively sought to undermine the traditional authority of Burma's sangha.

\footnotetext{
${ }^{21}$ The two wheels of the dhamma refers to the Theravada Buddhist understanding of the coexisting material (political) and spiritual realms. See Keyes (1978)

${ }^{22}$ Throughout Burmese history, pre-modern and modern state authorities have convened monastic councils with the ostensible purpose of "purifying the Vinyana", in other words, making sure that the sangha adhered to the Buddha's correct teachings. These councils provided rulers with a centralized administrative organ where they could supervise the sangha more effectively.

${ }^{23}$ Shweygin is the second largest monastic sect in Burma, while Sayadaw is a term of respect used to denote a senior monk, or the head of a monastery.

${ }^{24}$ The traditional head of the Burmese sangha
} 
State/Sangha Relations in Colonial Burma (1886-1948)

Upon Britain's victory in the Third Anglo-Burmese War (1885), and the resulting deposition of King Thibaw, the relationship between the state and sangha was characterized by a pervasive uncertainty which would eventually be transformed into a longer period of tumult. The British administrative system, marked by the introduction of a "rational" civil bureaucracy, was implemented in Burma, as elsewhere, to advance the economic interests of the colonial elite, and in turn, mitigated against the traditional authority of the sangha. While Buddhist monks still retained a tremendous amount of formal and informal power on the village level, they had little ability to shape the politics of the colonial administration, particularly during the $19^{\text {th }}$ and early $20^{\text {th }}$ centuries. In contrast, the British colonial authorities sought to secularize education, an area traditionally under the authority of the monkhood, while actively encouraging the spread of Christian missionaries (Taylor, 182). Of the colonial era, Michael Aung-Thwin (1985) argues that "religion was an extra-legal and rebellious force rather than a legitimator and integrator of society" (Aung Thwin 1985, 247). While Buddhist practices was not outlawed, the colonial authorities viewed it as an antiquated and exotic belief system antithetical to civilizational progress. In more concrete terms, the colonial authorities no longer materially supported the sangha, jeopardizing the latter's financial position (Taylor, 182). As a result, the material and symbolic threats to the monkhood posed by secular authority contributed to the sangha's politicization during the $20^{\text {th }}$ century.

In direct contrast to Burma's postcolonial leadership, the British did not appear to consider the sangha a serious threat to the political order, at least initially. Bruce 
Matthews writes, "In fact, the colonial policy of ignoring Buddhism as much as possible had seriously curtailed the ability of the British to deal with maverick monks or the wellorganized monasteries where large congregations lived immune from outside interference" (Matthews 2010, 31). Robert Taylor adds, "Monastic indiscipline faced little or no sanction, and the behavior of the monkhood changed, allowing members of it to become involved in secular activities, especially politics, in violation of strict Buddhist teachings" (Taylor, 79). When monks began to take a more active role in the nationalist movement, the British were forced to respond abruptly, managing local uprisings with fresh Indian military and police units sent from the crown colony. The jailing of prominent monks only contributed to a greater sense of unrest, leading to more episodes of organized violence throughout the early $20^{\text {th }}$ century.

Violent crackdowns coupled with the gross socioeconomic inequalities wrought by British imperialism led to periodic rioting during the early decades of the twentieth century. Through the formation of wunthanu (nationalist) organizations, monks and villagers publicly protested British colonial authority. The early nationalist organizations encouraged collective action with both secular political elites and traditional monks providing leadership (Ibid, 196). Prominent among these were the Saya Sen Peasant rebellion (1930-32), led by the eponymous former monk. Through direct appeals to religion and mystical conceptions of rule, Sen's political movement pledged to oust the British and restore the traditional monarchy with himself as king. The Sen rebellion was eventually put down but served as a rallying cry for members of the bourgeoning independence movement (Matthews, 31). Monastic political activism during the 1920's and 30's also took on an ethno-religious character, as nationalist monks organized 
protests demanding the removal of Indian immigrants (some of whom were Muslim). Azeem Ibrahim (2016) writes, "the anti-colonial riots of 1938 were as much aimed at the Muslim community as at British power" (Ibrahim 2016, 27).

Top-down secularization and the accompanying social dislocation brought about by modernization led to an identity crisis within the sangha. The rise of so-called "political monks" during this era, though not an entirely new phenomenon, was truly remarkable in terms of its scale. Such monks, who understood their vows as encompassing the defense of Buddhism and the protection of vulnerable Buddhists, joined the burgeoning nationalist movement. The General Council of Sangha Sammeggi under the leadership of prominent monk U Ottama, encouraged Anti-British resistance (Taylor, 121). Ottama's GCSS created a group of political monks to serve as tutors for burgeoning nationalists. It is generally estimated that roughly 200 monks were touring Burma in the 1920's preaching nationalist resistance (Ibid, 183-84). Arrested on multiple occasions during the 1930's for his nationalist speeches, Ottama eventually died in prison in 1939 (Linter 2009, 15).

The activities of politically-engaged monks can be juxtaposed against their more traditional counterparts who saw their primary role as transmitters of the Dhamma (teachings of the Buddha). More conservative elements within the sangha viewed the activities of Ottama and other GCSS monastics with considerable suspicion. As Matthew Walton (2015) recounts, a prominent Burmese monk argued that any monks who 
participated in the independence movement were in fact not "true monks" (Walton 2015, 511). ${ }^{25}$

While most monks did not support the British colonial project, many also feared that the sangha would lose its traditional place in Burmese society if it was to side with any specific political agenda. However, during the 1920's and 30's, politically engaged monks appeared to unite in their opposition to colonial rule and the demographic changes brought about by socioeconomic modernization, even if many monks did not directly participate in political activities. Monastic involvement in the nationalist Thakin Movement ${ }^{26}$ was highly visible, exemplified through political activism of U Wizara, who went on hunger strike of 163 days and eventually died in prison while protesting British rule (Lintner 2009, 15).

The temporary surge in sangha political activity rapidly declined during the 1940's as the pressure of Japanese occupation posed new challenges for the monastic community. The Japanese invading army had devised a scheme to coopt Burmese Buddhists into their Greater East-Asian Co-Prosperity Sphere, under the rationale that the Bamar population could be convinced that they shared more in common with Japanese Buddhists than British Christians. As Mendelson (1975) observes, "The Japanese made much of their common Buddhist cause with the Burmans, and there are many accounts of

\footnotetext{
${ }^{25}$ It should also be noted that leaders in Burma, and across Southeast Asia have often attempted to discredit politically active monks by leveling the claim that "fake monks" are behind subversive activities. In Cambodia and Laos, variants of this term have been employed by leaders of both pre-and post-Marxist regimes to undermine dissent.

${ }^{26}$ The Thakin or nationalist movement was largely organized by university students and preeminent Buddhist monks. It proved to be fertile ground for a new generation of political leadership, many of whom would attain formal political power in the post-colonial era.
} 
monks welcoming their troops to Burma, thus incurring the enmity of British and Chinese troops" (Mendelson 1975, 236). Yet, the large cultural gulf between the Japanese Mahayana and Burmese Theravada traditions was not easily overcome. Furthermore, the Burmese strategic rationale for supporting the Japanese stemmed from the latter's promise that they would provide Burma with independence, rather than out of any specific affinity for Japanese religion or culture.

While there are isolated examples of Buddhist monks collaborating with the Japanese, including a cultural exchange program established by two leading Burmese monks, the lion's share of the sangha remained politically disengaged and fragmented during the war (Ibid, 236-7). Mendelson writes, "After the war, there was no unified Sangha, nor any disciplined or well-honed organization primed to do the will of politicians" (Ibid 239). The uncertainty brought about by the Japanese occupation was amplified by the rise of the Burmese AFPFL (Anti-Fascist People's Freedom League), and their generally secular approach to politics. ${ }^{27}$ Independence hero Aung San, while showing deference to the nation's Buddhist cultural heritage, certainly did not support state-sponsored religion, and appeared poised to move Burma in a more secular direction. Upon Aung San's assassination, the elevation of U Nu to the rank of Prime Minister led to the resurgence of organized Buddhism as both governing philosophy and social force.

\footnotetext{
${ }^{27}$ The AFPFL (Anti-Fascist People's Freedom League) initially supported the Japanese, with several highranking military officers, including Aung San and Ne Win receiving training in Japan. In the late stages of World War II, the AFPFL recognized Japan's decline and switched allegiance to the Allies in the hopes of convincing the British to grant Burma formal independence.
} 
State/Sangha Relations Under the U Nu Parliamentary period (1948-1962)

Burma's brief parliamentary period was characterized by chronic political instability, as the first post-independence regime faced a variety of domestic and foreign threats to its rule. Lacking both the bureaucratic/administrative power to effectively deliver goods and services to Burmese citizens, and the coercive power to quash active rebellions, the $\mathrm{U} \mathrm{Nu}$ government, despite its ambitious social and economic agenda, relied upon the mobilization of religion as a means of garnering popular legitimacy. The following sections investigate this phenomenon in greater depth, with specific focus on Nu's failed attempts to unify a deeply fragmented sangha.

While U Nu's rule (1948-1962) proved to be a watershed moment in the resurgence of sangha authority in Burma, it was not completely divorced from the political and economic philosophy of the AFPFL. Nu, like many of his peers, embraced a state-driven socialist approach, exemplified through the top-down nationalization of Burma's industrial and agricultural sectors. In the interest of crafting a middle-ground between communism and capitalism, $\mathrm{U}$ Nu embraced state-planning but did not seek to abolish private property through collectivization schemes. Instead, his economic philosophy appeared to be more in line with a burgeoning European style socialdemocracy. In a speech delivered during Burma's Martyr's Day (1952), gathered through archival research, Nu publicly announced that "the government of Burma will press forward to a welfare state" (Sebald 1952, 10).

Nu's governing philosophy was also shaped by his own religious beliefs, which dictated that both communism and capitalism were ideologically opposed to the ideals set 
forth in the Buddha's teaching. In the simplest terms, $\mathrm{Nu}$ argued that communism concerned itself with the material needs of society at the expense of the individual's spiritual development (Frasch 2013, 127). Conversely, Nu was skeptical of capitalism, though late into his tenure as Prime Minister, he thought that the economy should encourage more profit-seeking behavior (Aung Thwin and Myint U 1992, 71). The middle way proposed by $\mathrm{Nu}$ in domestic politics also informed his neutral stance during the Cold War. Hoping to play rival great powers off each another, $\mathrm{Nu}$ framed his version of socialism in lukewarm terms that would attract neither sympathy nor reprobation from the United States, Soviet Union, and China.

In contrast with much of Burma's post-war elite, $\mathrm{Nu}$ imagined a very public role for Buddhism in the newly independent state. While Nu's frequent appeals to Buddhism as a governing ideology were in some measure a reflection of his personal convictions, it was also a useful strategy aimed at insulating his rule against domestic and foreign agitators. From Nu's perspective, in such dire conditions, religion remained the only feasible means by which his government could assert its authority. Yet, his attempts to impose a pan-Buddhist national identity on a deeply divided state was met with rejection from moderates and religious hardliners alike. The sangha itself, though positioned as a potential ally, was divided along sectarian and political lines, as a large contingent of monks siding with a rival faction of the $\mathrm{AFPFL}^{28}$, came to view state-sponsored Buddhism as a threat to their autonomy (Mendelson 1975, 348).

\footnotetext{
${ }^{28}$ The Anti-Fascist People's Freedom League was divided into two factions by 1958. The "clean AFPFL" led by U Nu's electoral coalition encountered opposition from the "stable AFPFL". Upon General Ne Win's coup in 1962, the stable AFPFL was disbanded.
} 
Throughout the immediate post-independence era (1948-1962), threats posed by communist factions (White Flag and Red Flag) ${ }^{29}$, breakaway ethnic groups (Karen and Kachin), and China's retreating Kuomintang army, dictated that $\mathrm{U}$ Nu govern in a manner highly palatable to the majority Burmese population. Emerging from the ashes of World War II, Burma's economy was destroyed, the civil bureaucratic administration had to be rebuilt, and the military was too preoccupied with battles on multiple fronts to be successfully deployed in the case of civilian unrest. In a particularly harrowing description, Mary Callahan (2013) writes that by 1949 roughly half of the government's armed forces had mutinied. (Callahan 2003, 115). She adds, "With the departure of the British, the AFPFL-victorious in the 1947 parliamentary election-may have had a nominal claim on whatever authority could be claimed, but de facto political power in Burma remained beyond the grasp of anyone based in Rangoon" (Ibid, 116). Since real power was in the hand of regional warlords, the state had to rely upon these powerbrokers to establish law and order outside of the capital (Ibid, 144). MA Myoe (2009) adds that insurgencies were so powerful in the late 1940's that the Myanmar government was described by international media outlets at the time as the "Rangoon" government (Myoe 2009, 16)

Thus, Nu's Buddhist Socialism, despite its apparent inconsistencies, represented an attempt to unify a divided country, or at the very least provide a loyal base of support among traditional Buddhists. By aligning himself with the traditional authority of the sangha, $\mathrm{Nu}$ hoped to reinvigorate the imagined symbiotic relationship between the state

\footnotetext{
${ }^{29}$ White Flag communists, the larger of the two groups, was more conciliatory toward the AFPFL, while the Red Flag party espoused a Troskyist ideology, and advocated for violent revolution.
} 
and Buddhism during the precolonial era. When $\mathrm{U} \mathrm{Nu}$ pushed for the convocation of the Sixth Buddha World Conference (1954) with the eventual goal of implementing Buddhism as the official state religion, the more secular elements of the AFPFL, ethnoreligious minorities, and moderate Buddhists all voiced their disapproval (Matthews, 34).

Under the Nu/AFPFL parliamentary regime, Buddhism was lavishly patronized through the establishment of Buddhist schools and the restoration of missionary efforts in both Burmese and minority ethnic regions through the Ecclesiastical Courts Act of 1949. U Nu's public support of Buddhism was exemplified by the construction of 60,000 sand pagodas with the ostensible purpose of bringing peace to a country rife with conflict (Taylor, 292). His patronage also extended to the establishment of lay mediation centers in the Vipassana (mindfulness) tradition, which he had hoped would attract practitioners from Southeast Asia and beyond. Nu also pushed for a return to Buddhist education, which would reestablish the traditional monastic dominance in this field. At the same time, responding to pressures from hardline Buddhist monks, $\mathrm{U}$ Nu also banned cattle slaughter, a decision that alienated members of the minority Christian, Muslim, and Animist communities, but perhaps more importantly, the secular armed forces (Matthews, 35).

In 1951, as documented in archival sources, $\mathrm{U}$ Nu sponsored the Buddhist Sasana Council Act, which spelled out in no uncertain terms that the council should act as a government agent for religion (Spencer, 49). Among its many objectives, the council allocated funds for the support of missions, the teaching of the Pali language, the establishment of a college for missionary training, and the creation of meditation centers 
(Ibid, 50-52). The Sasana Council, along with their responsibility to publicly promote Buddhism, also had disciplinary powers. The Council supervised monastic exams and held the power to disrobe monks who had strayed from the monk's code of conduct (Ibid, 50-52). In personal discussions with U.S. Ambassador to Burma, William J. Sebald, in 1952, U Nu had proposed to take "drastic actions to clean up the order by tightening discipline and disrobing avowed communist monks, as communism and Buddhism were irreconcilable" (Sebald 1952).

U Nu's attempts to revive and unite the sangha were not without significant challenges. While the government attempted to include all sects, political differences quickly emerged. The Young Buddhists Association (YBA), who acted in part as moral guardians in society, clashed with the KSA (Association of Monastery Abbots), a group formed for the exclusive purpose of supporting the AFPFL's clean faction. Both competed over government funding and were split along the lines of creating Buddhism as the state religion. (Mendelson, 324-331).

Ultimately, the aim of the Buddhist Revival in Burma was framed as an act of state-sponsored "purification" or a means of ensuring that Theravada Buddhism in Myanmar remained true to doctrine. In reality, these organizational efforts undermined unity within the sangha, and created new tensions with the state. Rather than rally monks to $\mathrm{Nu}$ 's cause, the state patronage of Buddhism under $\mathrm{Nu}$ further amplified sectarian divisions within the sangha by raising the economic stakes of non-cooperation. Mendelson remarks, "This operation was unsuccessful ultimately because the of the opposition and independence of both the sects and the political associations, including the 
KSA itself and the YBA, which instead of bringing unity to the Order, only reflected the disunity, factionalism, and conflict endemic to the politics of the time." (Mendelson, $355)$.

Of the U Nu era Robert Spencer observed, "There is a high degree of mutual interdependence of religion promoted by government, and in turn, promoting government" (Spencer, 100). This observation, while certainly correct, does not do justice to the role the $\mathrm{Nu}$ government played in deliberately fostering these patterns of interdependence. There is little doubt that the resurgence of Buddhism in Burma at the time was a deliberate top-down project. Matthews writes, "The high pitch of Buddhist enthusiasm generated by $\mathrm{U} \mathrm{Nu}$ had given the sangha an understandable presumptuousness as it relished its role as co-architect of a future Burma" (Matthews, 35). In short, the sangha's empowerment during the parliamentary era did not merely arise from the end of British colonial authority, but through the rhetorical and organizational support provided by the Nu regime itself.

Ironically, U Nu's political fate was sealed over his decision to make Buddhism the official state religion in 1961. Facing the prospects of a collapsing economy coupled with vigorous armed conflict against both Karen ethnic separatists and Chinese KMT regiments in the northern part of the state, $\mathrm{Nu}$ took a political gamble and pushed for the state religion law, in the hopes of enhancing his status among the Buddhist sangha and Burmese nationalists. However, sensing blowback from the passage of Article 3 (the state religion law), Nu then sponsored a subsequent amendment (article 4) which would guarantee freedom of religion for all citizens. While the latter move was designed to 
appease more secular elements within his own governing coalition, it was publicly perceived as indecision in a time of crisis. In response to Article 4, over 500 hardline monks attacked $\mathrm{U} \mathrm{Nu}$ at the Shwedagon Pagoda, claiming that the article effectively made all religions the state religion (Mendelson, 353). The political disarray brought about by Nu's maneuvering, in some part, led to military coups in 1958 and 1962, the second leading to the long-term suspension of state-sponsored religion.

Concurrently, the extensive period of lawlessness during the Nu parliamentary period was a mainly a function of low state capacity, as the poorly equipped Burmese police and military were not able to contain local violence. Murder and theft were at their highest levels since the World War II years. Robert Taylor observes that in 1947 the murder rate was twice as high as 1940 (180 per million population), while banditry was up from 41 per million to 1,260 per million (Taylor, 254). Yet, $\mathrm{U}$ Nu at least in public, viewed this problem as primarily moral in character, as he lamented a decline in moral and religious standards across the country. Josef Silverstein (1980) argues that Nu saw religion as means of instilling "social and moral values that would in turn lead to an end in insurgent activity, a reduction in criminality, and a reintegration of society" (Silverstein 1980, 152). Nu's minister of religion U Win echoed these sentiments, "With this decline in the structure of sangha society came the deterioration in the sangha's code of conduct. Lay morality also declined in consequence. With this general deterioration in human morality, breaches of law became rampant" (Mendelson, 270).

The post-colonial state also struggled in terms of its administrative capacity, as centralized state-planning failed to achieve its objectives. Taylor reports that during the 
immediate post-war years, most incomes remained at great depression era levels, while consumer consumption dropped between 70 and 90 percent of its pre-war levels (Taylor, 259). The exception during this era was growing military control over economic activity. By 1958, the Defense Services Institute, later renamed the Burma Economic Development Corporation, became the state's largest economic entity (Ibid, 260). Callahan observes, "Gradually, military-building activities expanded into the realm of state-building" (Callahan, 172). Throughout the 1950's, civil authorities increasingly lost control as the military began to claim a greater stake in the nation's future (Ibid).

Specifically, morale within the state bureaucracy was low as important promotions went to either military officers, or those closely connected to the military.

By 1958, elite political fragmentation reached unmanageable levels, corresponding with a formal split in the AFPFL into "clean" and "stable" factions. General Ne Win, upon the invitation of parliament, took power and formed a caretaker government, before returning power back to U Nu in 1960. In 1962, General Win took power once again through a second decisive coup marking the end of Burma's brief democratic experiment, while also ushering in new strategies for managing the Burmese sangha.

State/Sanga Relations Under the Ne Win regime (1962-1988)

Shifting from a period of outward cooptation of the Burmese sangha brought about by U Nu's reliance on organized Buddhism in a chaotic political era, Ne Win's reorganization of government led to a long period of coercive policies imposed against the sangha. Upon taking the reins of power and arresting prominent members of the $\mathrm{Nu}$ 
regime, including the Prime Minister himself, Ne Win's first prerogative was to initiate the absorption of state funds into the military apparatus as a means of stifling all domestic challenges to his rule. In turn, Ne Win also cut off subsidies allocated for the promotion of Buddhism (McCarthy 2010,13). Prominent among his concerns was the threat a politically potent sangha could pose to his leadership. His fears were not without some merit, as recent Burmese history confirmed the powerful role anti-government monks could play in mass protests.

Highly suspicious of "insurgents donning the robe" (Kawanami 2013, 110), Ne Win embarked upon numerous attempts to put the sangha under his thumb through the implementation of new Sasana Councils. Officially, the purpose of these councils was to establish strict moral guidelines for monastic practice, assuring that monks would adhere to the spirit of the Vinyana. In practice, they marked an attempt on the part of the Win junta to exercise greater political control over the monkhood by establishing new guidelines for disrobing politically-engaged monks. In 1980, Win convened the Congregation of Buddhist Sects, where the two formally independent ministries of Home and Religious affairs were fused together to establish singular authority over both national security and monastic affairs (Ibid, 111). In addition, sangha registration became required in 1981, with relevant identification cards assigned to monks. Kawanami observes that monastic reorganization in the 1980's was "fundamentally a surveillance system aimed at monitoring the monastic infrastructure at regional levels" (Ibid, 112). Under the new arrangement, monasteries would report to regional and township councils, who were staffed by government appointees and retired military officers (McCarthy, 13). 
Archival research reveals that although particularly active in stifling monks who expressed political opinions contrary to the regime, Win conveniently refused to exercise punishment against his own monastic political supporters, thus recreating the old system of regime insiders and outsiders in his own image (Pierson, 41). Despite Ne Win's own secular governing ideology, expressed prominently in his party's founding treatise "The System of Correlation of Man and His Environment"- a document which made no explicit reference to the proactive role of religion in society- Win soon realized that he could not fully curtail the political activities of monks. Monks continued to protest the government publicly, though now, in direct contrast with the U Nu era, they were typically met with severe repression.

Ne Win's coercive strategies toward the sangha culminated in three major crises. In 1965, Ne Win embarked upon a monastic registration scheme under the guise of an “All-Sect Sangha Congregation Meeting”. In protest, anti-government uprisings occurred throughout the country, particularly in Mandalay, Burma's traditional Buddhist spiritual center. Harry H. Pierson (1968) recounts, “On April 27, 92 pongyis (monks), were arrested and accused of having been involved in repeated political activities and economic insurgency under the cover of religion and sasana" (Pierson 1968, 57.). At the same time Ne Win embarked on a public campaign to discredit "pseudo-monks" (Ibid, 38). Pierson argues that while Ne Win wanted to keep monks out of politics, "achieving and practicing this goal is not easy and perhaps not possible" (Ibid, 39). Monastic participation in the registration plan was scarce, despite official orders to the contrary (Matthews, 36). 
In another dramatic event, protests erupted at the funeral of former UN Secretary General U Thant (1974), who was refused a proper state burial. This led to the arrest of a large number of monks "who were forced to take off their outer-robes and sit like criminals before being taken to the interrogation center" (Fink 2001, 57). Subsequent public disapproval over the treatment of monks set off further protests in the capital which were also met with harsh government reprisal. Finally, the infamous 1988 prodemocracy protests culminated in over 3000 citizens killed or injured which led to Win's resignation and the creation of a new military government (Oxford Burma Alliance.org).

While the Ne Win era is characterized by clear, numerous examples of antimonastic crackdowns, it should also be noted that Win's hostile actions were ironically juxtaposed against public ceremonies designed to show his support for Buddhism. When he convened the 1965 All-Sangha Convention, he did so as 'propagator of the faith' (Mathews, 36). Toward the end of his rule, Win made public donations to the sangha (McCarthy, 13). He also selected his former political rival U Nu to edit Buddhist texts (McCarthy 2008, 301). As Keyes notes, one of Win's last acts as ruler was the construction of the Maha-wizaya stupa on the hill where the Shwe Dagon pagoda is located (Keyes, 25). It is difficult to infer whether these acts were designed to cultivate sangha support, or more indicative of Win's infamous reliance on cosmological Buddhism, especially numerology, to make important political decisions (Ibid). ${ }^{30}$

Apart from tightening his grip over organized religion, Ne Win's other objective at the time was the reorganization and modernization of Burma's coercive apparatuses.

\footnotetext{
${ }^{30}$ It is widely rumored that $\mathrm{Ne}$ Win's reliance on fortune tellers informed his political decisions.
} 
During this era, the military siphoned off important public resources into its private accounts at the expense of a fledgling civilian bureaucracy. While civilians did hold posts in the Win bureaucracy, their independence from the ruling BSPP was far from secure. The Win regime was not technocratic by nature, and it remains unclear as to whether the military officers had the training required to administer the economy. Myo Tun (2011) writes, "the economic policies under the Burmese Way to Socialism and the mismanagement of the economy under the military initiative for 26 years made it impossible to create strong state structures and steer the economic development" (Myo Tun 2011, 77). Economically, the Burmese military regime pursued autarkic policies designed to insulate the regime from the kind of social changes brought about by globalization in other parts of Southeast Asia. While economic data from this period is notoriously unreliable, as the Win regime made a conscious effort to disguise the magnitude of its economic woes from both its people and the international community, there were several major price shocks during the era which led to mass protests. The 1988 protests were in part generated by the sudden and inexplicable demonetization of the Burmese Kyat.

Surprisingly, despite Ne Win's focus on establishing law and order within lower Burma and the ethnic states on the periphery, there does not appear to an appreciable increase in military spending during this time-period (Taylor, 339). Rather, it appears that the military elite thrived through informal business connections, while rank-and-file soldiers were provided dilapidated second-hand equipment with which they were expected to fight low-level insurgent battles on the frontier. 


\section{State/Sangha Relations Under Regime Transition (1988-present)}

Following Ne Win's formal resignation in 1988, the BSPP was dissolved and the remaining members of the military junta renamed their regime the State Law and Order Restoration Council (SLORC). In the aftermath of the political chaos brought about by the 1988 protests, the restored military junta's main objective was to ensure that future civilian uprisings wouldn't result in regime collapse. Around this time of domestic political uncertainty, insurgents in the north and east also stepped up their activities in the hopes of catching the military government off-guard (Selth 1996, 17). In 1990, the SLORC's first Chairman Saw Maung suppressed a new round of pro-democracy demonstrations (McCarthy, 302). During these events, 7000 monks were attacked by government forces, resulting in a nationwide spiritual boycott culminating in roughly 20,000 monks refusing to accommodate military-members' acts of merit (Matthews, 42021). Shortly after, the SLORC instituted a new law (order 7/90) which banned all monks from engaging in political activities (Ibid, 303).

In the immediate aftermath of the ' 88 protests, the generals, looking to increase their coercive capabilities, purchased new arms shipments from Singapore and Pakistan. Yet, the most evident change was the massive modernization effort initiated by the military in 1989, as its size grew by more than 60 percent in four years (Selth, 19). Economically, shortly after attaining Least Developed Country status, the SLORC junta began the process of liberalizing the economy. While Burma did begin to experience higher economic growth rates during the early 1990's, the sustainability of this growth was hijacked by the military's shifting attention to internal security threats (Myo Tun, 
80). Counterinsurgency operations, particularly in Karen State accelerated during the 1990's, thus putting a significant strain on the state's economic and human capital.

During the 1990's, apart from its aggressive approach toward the sangha, the junta also attempted to actively sponsor Buddhism as a means of countering the growing popularity of the National League for Democracy. McCarthy remarks, "By assuming a high profile in the collection and donation of monies for the restoration and construction of pagodas and Buddhist images, the Tatmadaw attempted to establish a monopoly over the performance of some private merit-making and the more public religious services" (McCarthy, 309).

The peculiar mix of cooptation and coercion applied against the sangha were typified during the SLORC era. Bruce Matthews writes, "Ironically, at the same time that political repression entered its harshest phase, the SLORC regime encouraged programs for the promotion of Buddhism, including the teaching of the faith in high schools and improving standards of monastic education, and the Ministry of Home and Religious Affairs continues to offer support for the upkeep of pagodas" ( Matthews, 417) The postWin military junta sought to rebrand itself, pledging a "disciplined" transition to democracy. By promising to hold parliamentary elections, the regime appeared to yield to popular domestic and international pressure. Instrumental in the pro-democracy movement were the numerous monks who had participated in the 1988 protests and had symbolically turned their alms bowls over in direct defiance of the military regime. However, after the 1992 elections resulted in a large victory for Nobel Laureate Aung 
San Suu Kyi's National League for Democracy, the SLORC regime refused to recognize the results, culminating in Suu Kyi's house arrest and the continuation of military rule.

In 1997, more personnel reshuffling within the junta led to the creation of the State Peace and Development Council (SPDC). While some of the core leadership changed, the strategies employed against the sangha remained essentially the same. In terms of the SPDC's relationship with organized Buddhism, in 1998, "Lt. General Khin Nyunt, then one of the leaders of the junta (later deposed and put under house arrest) took charge of placing a new crown (hti) on the Shwe Dagon" (Keyes, 25). Kawanami also observes that the government saw the utility of promoting Buddhism as a unifying ideology during the 1990's (Kawanami. 119). Bruce Matthews has argued that the SPDC's appeal to religion reflects its own 'moral poverty' (Matthews 1997, 18). During the 1990's, both the SLORC and SPDC made lavish donations to the sangha. Matthews writes, "Many members of the sangha, largely of an older age, have also been compromised to some extent by accepting emoluments from the regime, (including now, for the first time, air-conditioned residences in some monasteries" (Ibid).

During the 1990's, the reconstituted military regimes also sought to exert coercive power over the sangha. Through the State Sangha Mahanakaya Council, the regime successfully prevented members of the opposition NLD party from taking monastic vows. The SPDC has also established greater control over the administration of the sangha, constantly reshuffling prominent monks to prevent the growth of alternative bases of power within the national sangha (Schober 2005, 119). Despite these efforts, monastic actors would still play an important role in opposition politics. 
In 2007, Burma once again erupted into national protests, this time spearheaded by monks who marched to Aung San Suu Kyi's house and demanded her release. Taylor estimates that roughly 10,000 monks participated in the protests around Yangon (Taylor, 425). The protests were met with harsh government reprisal, leading to the death and imprisonment of several monks, with others forced to flee to the Thai border. The Burma Campaign reports that "monks were forcibly disrobed, severely beaten, kicked at taken away by the security forces". The campaign's report also indicates that a total of 52 monasteries were raided during the demonstrations (Burma Campaign UK).

Under Thein Sein's rule (2011-15), the sangha had once against split along new political fault lines. Most notably, a growing number of nationalist monks, as exemplified by the "969" movement and Ma Ba Tha, sought political concessions from Sein on the Muslim question. Certain members of these organizations, ostensibly dedicated to the defense of Buddhist religion and culture, have also sought to limit the growth of Islam within Burma. At times, these outspoken monks have vilified Muslims, linking them to extremist violence and high-birth rates (Howe 2018). In particular instances, anti-Muslim violence have followed powerful speeches by Buddhist nationalist groups (Human Rights Watch 2013).

Sein's outspoken repudiation of Islam, public gift-giving ceremonies, and his eventual decision to enter a monastery after his electoral defeat serve as evidence that he attempted to cultivate some measure of support from the sangha. In addition, following the aftermath of the incredibly destructive Cyclone Nargis, more monks were taking an active role in community development, filling in for a poorly functioning civil 
bureaucracy. Sein's rhetorical support for nationalist monks, was shortly followed by the government's implementation of Race and Religion Protection Laws, which among other things, restricted religious intermarriage between Buddhists and Muslims. The empowerment of radical monks under Sein was tested under the new NLD leadership which swept to power in the 2015 elections.

With Aung San Suu Kyi's NLD formally in power, the shape of the future relationship between state and sangha remains an open question. While Suu Kyi has written extensively on the compatibilities between Buddhism and democracy, she has not pushed for a greater political role for monks in society. In addition, Suu Kyi has been called into question by western human rights observers over recent episodes of ethnic cleansing in Rakhine State. While ultra-nationalist monks have viewed Suu Kyi's evasive rhetoric as a victory, their position in 2017 Burma is less secure than it was under Sein. In an act designed to regain control over politically active monks, the conservative State Sangha Nakaya Committee recently instituted a preaching ban against U Wirathu, a man who Time Magazine referred to as the Burmese Bin-Laden and banned all religious activities of the nationalist monastic organization Ma Ba Tha (Beech 2013).

Synthesizing Low State Capacity and State/Sangha Relations in Burma

Looking broadly at the relationship between state capacity, regime strategy and religious organizations in Burma, regime elites have demonstrated a clear tendency to cycle between policies of cooptation and coercion. Since its inception as an independent state in 1948, Burma has lacked a high degree of bureaucratic/administrative capacity. In part, this may be best explained as a consequence of a long-term historical process 
beginning with Britain's decision to administer Burma via its crown colony in India; never fully committing the resources required to build a strong civilian bureaucracy. This was exemplified through Britain's extensive reliance on non-native administrators, most of whom fled Burma during World War II. Because of constant warfare throughout the 1940's and early 1950's, the Burmese military became the only viable institution in the country. Since then, the Tatmadaw has internalized the idea that it alone can protect Burma from all enemies, domestic and foreign (Callahan, 215). Its superior organization vis-à-vis other bureaucratic entities has created a vicious circle in Burma, as the military continues to dominate an outsized portion of the domestic economy, thus further strengthening its position via the civil bureaucracy.

In more concrete terms, Ne Win's Burmese Way to Socialism, which featured the nationalization of agriculture and nascent industry through import-substitution policies, kept the Burmese economy isolated from much of the region and the international economic community. Aung Thwin and Myint-U write (1992) “The regime's idea of socialism included the nationalization of some 15,000 firms, the establishment of a massive public sector represented by state corporations called SEES (State Economic Enterprises), forcing approximately 200,000 Indian nationals who controlled a large part of the economy to leave the country" (Aung Thwin and Myint-U 1992, 72). Reliance on the boom and bust cycle of raw commodities, despite price controls, exposed Burmese agricultural workers to a high degree of economic uncertainty. The inability to translate a socialist political agenda into successful governance was also indicative of a regime struggling with the legacy of low-state capacity. Hlaing (2003) remarks "due to its limited technical, financial, and human resources-the resources needed to meet the needs 
of the public and to allow local state organs to function- the BSPP failed to expand the state's share of the economy and prevent the emergence of private business people." (Hlaing 2003, 57). While the military dominance over society is perhaps not as strong as it was during the Ne Win era, military officers still form "an exclusive social order" which remains highly isolated from the everyday affairs of the average Burmese citizen (Callahan, 211).

Politically, successive military regimes have never shown any real interest in developing a functional bureaucracy as it could potentially threaten the military's firm grip on power. Neil Englehart writes, "The failure to build infrastructural power has been the central problem of Burma under military rule.... far from resolving the problem of civilian administrative capacity, successive military governments have continued to treat the civil service as an adversary, repeatedly purging it and inserting military officers to oversee operations (Englehart 2005, 631-632). In addition, as in other authoritarian contexts, the Burmese military never sought to develop civil society organizations outside the formal control of the state (Steinberg 1997).

Unlike its authoritarian counterpart in Vietnam, Burma's attempts to build topdown mass party organizations have failed repeatedly. Ne Win's BSPP, though ambitious at first, quickly dissolved as administrative organs became hollow expressions of state power, turning citizen participation into a mere formality (Taylor, 316). Specifically, the BSPP scheme included the formation of worker organizations and a youth wing, which once they were deemed unsuccessful, led to an increasingly non-ideological approach to 
rule. It is also possible that the BSPP was merely a façade, instituted by Ne Win as an ideological cloak designed to mask highly personalized rule.

In terms of its relationship with the sangha, Burma stands out as a clear example of a state featuring low bureaucratic/administrative capacity and low coercive capacity attempting to alternately coerce and coopt the sangha in hopes of establishing lasting control over its membership. U Nu's double-edged efforts to co-opt "state monks", while introducing a new administrative organ which could more effectively punish antigovernment monks, resulted in chaos as different sects fought for government perks, while moderates and hardliners clashed over the question of Buddhism as state religion. While Nu's ouster was not simply a consequence of his less than secure grip over politically influential monks, the state-religion controversy in part prompted the avowedly secular Ne Win to institute a coup.

Ne Win's aggressive treatment of politically active monks, as exemplified by crackdowns during the 1965 monastic registration scheme, the 1974 U Thant Funeral Crisis, and the infamous 1988 protests were symptomatic of a regime which despite their best efforts could not effectively infiltrate monasteries or arrest the number of monks required to prevent recurring episodes of protest. Ne Win's reorganization and registration of the sangha through the State Sangha Council appeared to have little real impact on the political activities of monks throughout Burma. Win's crackdowns likely empowered his enemies over time, further splintering the sangha, and paradoxically making individual politically-minded monks harder to identify and control. Kawanami writes, "The government, which aimed at integrating both monks and nuns into a 
centralized structure of the monastic community, has not been able to penetrate spheres of influence and autonomy operating in private monastery and nunnery schools, however" (Kawanami, 116).

Lacking the means to fully coopt a divided and highly localized sangha, successive Burmese regimes after $\mathrm{U}$ Nu have frequently relied upon coercion, a strategy that has done lasting damage to their reputation, if not their formal power. Crackdowns against monks in 1988 and 2007, resulted in the end of two military juntas, though not the end of military rule. More importantly, the scale of sangha protests in the aforementioned protests is indicative of how little control the military exercises over monks. Contemporary sangha cooptation appears more token than systematic, with little evidence to suggest that the current electoral authoritarian regime will recreate $\mathrm{U} N$ 's patronage system.

In terms of coercive power, the SLORC and SPDC took clear steps to increase military size and spending. As post-1962 military governments had never put any serious consideration into either attacking or repelling neighboring states, it is likely the case that these changes have been pursued in the interest of stifling domestic opposition. As of 2015, Burma has the largest standing army among the Southeast Asian states featured in this study. Correspondingly, it now devotes a much larger share of its budget to the military than its neighbors. Yet, increases in troop size do not necessarily translate to accompanying growth in coercive capacity. It does not seem as though today's Tatmadaw is significantly better equipped to quash domestic insurgency than it was 15 or 20 years ago. Most of its military hardware is second-hand, with the average soldier lacking the 
basic resources required for their mission. (Selth,150). In addition, the military's fundamental inability to bring ethnic armies under its thumb persists, with conflict in Kachin and Rakhine states still raging well into 2017.

Corresponding enhancements in counterintelligence and surveillance technology also suggests a deep-seated fear of domestic uprising. Unsurprisingly, Burma, as of 2014 has committed a larger share of its GDP to military spending than any of its neighbors in the region. Though it should be made clear that not all military budget allocations are for equipment and troops. Due to a lack of civilian oversight on military affairs, it is unclear exactly what percentage of the budget is spent on traditional military expenses, as opposed to that which is siphoned off into the military's private accounts. Andrew Selth writes, "The term 'defence spending', for example, is nowhere clearly defined and funds for other defence-related activities are scattered throughout the Burmese budget under different headings." (Selth, 11). Furthermore, official military spending does not capture revenue raised from illicit activities, a sizable source of revenue, particularly for generals operating in the border regions.

In terms of the contemporary relationship between the Burmese state and religion, the Association of Religion Data Archives (2017) cites government regulation of religion as extremely high, measuring 9.1 out of 10 , though this measure does not focus narrowly on the actual relationship between state and sangha in Burma (ARDA 2017). Government repression is more typically applied against ethno-religious minorities than Bamar Buddhists. This data also shows that the government's favoritism of religion is also extremely high at 8.1 out of 10 , indicating that official government support for 
Buddhism was actually quite robust as recently as 2008 (ARDA 2017). This fascinating mixture of religious favoritism and repression is not the function of a particular regime, as the SLORC approach did not differ dramatically from that of Ne Win's BSPP. In broad terms, this data suggests that the Burmese military junta, at least through the late 1990's and early 2000's engaged in activities designed to promote state-sanctioned Buddhism, while cracking down on religious actors thought to pose a threat to the state.

In terms of bureaucratic/administrative power, Burma has ranked last in the region since at least 1996, with a consistent government effectiveness rating between -1 and -1.5 (Kaufmann and Kray 2017). It should be emphasized that this rating is very low, even by regional standards. This data is an important qualifier to official government claims that robust GDP growth over the past decade is evident of an economy on the rise. In fact, underdeveloped physical infrastructure and political instability has scared away foreign direct investment. While the SLORC leadership has liberalized the economy after recognizing the lasting damage done under Ne Win's BSPP regime, military-controlled economic activity has sapped competition and efficiency in the domestic market.

In terms of regime-sponsored violence, Mark Gibney's et al.'s Political Terror Scale (2017) has consistently identified Myanmar as a country at the highest end of this scale, thus indicating a high degree of government repression against civilians. Since 1992, Myanmar has received a score of either 4 or 5 every year. According to the scale, a score of 5 indicates that "terror has spread to the whole population. The leaders of these societies place no limits on the means or thoroughness with which they pursue personal 
or ideological goals" (Gibney et al. 2017). There does not appear to be much improvement in this situation under the NLD government.

At present, Burma's military regime still holds a high degree of informal power as the typical pattern has been one of granting some democratic concessions, while still exercising control over the state's most important ministries. Through retaining exclusive power over the Ministry of Home and Religious Affairs and establishing institutional veto power in the state legislature, the military has a high degree of governance authority. However, despite episodes of political crisis, the military still manages to keep itself in power. Slater and Fenner (2011) write, "More unstable regimes like those in Myanmar and Zimbabwe get buffeted by recurrent crises of much larger magnitude that require more drastic measures to manage. Yet even these drastic measures do not place the regime on solid, predictable footing" (Slater and Fenner 2011, 18). Despite these challenges, there is little sign that the durable (if not strong) military regime will yield to democracy anytime soon.

The following chapter will examine state/sangha relations in Thailand and Malaysia, two states featuring high levels of coercive and bureaucratic/administrative power. The successful state cooptation of monks in the Thai case and the effective administration of state-sponsored Islam of in Malaysia are in direct contrast to historical patterns of monastic contestation witnessed in Burma. 


\section{THAILAND AND MALAYSIA}

Despite significant differences in religion, ethnic composition, and colonial histories, Thailand and Malaysia serve as prime examples of states with strong bureaucratic/administrative and coercive power whose regimes have relied upon patterns of explicit cooptation and selective coercive tactics to keep organized religion under their thumb. While dissident voices have emerged in both countries, particularly in recent decades, Malaysia's position as promoter and regulator of Islam remains secure; by contrast, elite political fractionalization in Thailand has put some limits on the state's ability to regulate Buddhism, particularly in the $21^{\text {st }}$ century.

The following chapter first traces the Thai state's relationship with organized religion, demonstrating how the growth of the former is reciprocally linked to its regulation of Theravada Buddhism. In direct contrast with Burma, where successive regimes have viewed Buddhist monks as an unreliable and occasionally adversarial force, the Thai sangha was an important partner in the state's broader nation-building project throughout the twentieth century. Since the 1990's, the Thai sangha has mirrored the broader political atmosphere in the country, as politically active monks ${ }^{31}$ have aligned with factions on different ends of the Thai political spectrum.

The second half of this chapter analyzes the Malaysian state's highly effective administration and regulation of its preferred brand of Sunni Islam. Specifically,

\footnotetext{
${ }^{31}$ It is important to reiterate, as in Burma, not all Thai monks consider themselves political or care to engage in political activities. The definition of what constitutes "political" behavior also varies on a caseby-case basis.
} 
successive authoritarian regimes have used the official levers of the state bureaucracy to finance religious schools and state-friendly economic enterprises in the interest of maintaining Islamic religious and cultural hegemony in a diverse country. Despite having a more diffuse structure of rule than Thailand, the Malaysian state's religious bureaucracy has maintained its dominant position in society through patronage and political cooptation without having to frequently employ widespread coercive measures. In regional terms, the Malaysian state's bureaucratic/administrative apparatuses are more sophisticated than either Burma or even Thailand's, providing an ideal example of how a state with strong bureaucratic/administrative power can more effectively counter threats emerging from organized religion. The successful cooptation and control of religiouslyinspired anti-regime opposition in Malaysia ${ }^{32}$ is indicative of how a regime in a strong bureaucratic/administrative state regulates the opposition, instead of having to resort to violent crackdowns.

\section{Thailand}

The modern Thai state's raison d'être is inextricably linked to its historical relationship with organized Buddhism. Religion has served as a pillar of legitimacy for the monarchy, particularly during periods of internal conflict and economic downturn. During the $19^{\text {th }}$ century, Buddhism played an essential role in the state-building project. Specifically, Charles Keyes (1971) notes that all religious practice outside the king's direct control "represented a potential threat to national integration because its local manifestations were articulated with autonomous polities" (Keyes 1971, 552). As the

\footnotetext{
${ }^{32}$ Islamic opposition to the Malaysian regime is largely institutionalized through the PAS party.
} 
Thai monarchy embarked on its own state-building project through the gradual process of internal colonization, religion was mobilized as a unifying ideology that soon became fused with the socially-constructed idea of the Thai nation. In the tribal northeast and the Muslim south, the Thai state's encroachment into previously ungoverned territory were met with violent reprisals, a legacy that continues well into the $21^{\text {st }}$ century ${ }^{33}$.

Throughout the $20^{\text {th }}$ century, the conservative institutions of nation, religion and king have been exploited by successive Thai authoritarian regimes to marginalize political opposition and delegitimize alternative interpretations of state-patronized Buddhism. As a reliable partner during the immediate post-World War II era, and Cold War period, the sangha was mobilized for regime-sponsored education and development projects, pursued with the goal of containing the spread of communism from neighboring French Indochina. Of the Cold War era, Eugene Ford (2017) notes, "Under its pressures, a previously closed religious community slowly became more politically active while its hierarchical leadership attempted to maintain and largely succeeded in enforcing the traditional conservativism." (Ford 2017, 11). The responsiveness of the Thai sangha to frequent coups and power transitions betrays the reality that religion has served a broader instrumental function: to bolster the legitimacy of the state under both military and civilian regimes. ${ }^{34}$

\footnotetext{
${ }^{33}$ For a more detailed discussion of the relationship between the Thai nation-building project, statesponsored Buddhism and Muslim resistance see Jerryson (2011).

${ }^{34}$ This is not to say that the Thai sangha is politically homogeneous or passive. The fragmentation of the Thai sangha during the latter portion of the $20^{\text {th }}$ century highlights the diversity of practice within Thai Buddhism.
} 
While the Thai sangha has helped legitimize the regime/monarchy nexus, there have always been important sectarian and political cleavages within the monastic community that deserves closer attention. These divisions have been particularly visible in recent decades as elite and mass political polarization in Thailand has drawn the sangha into competing political factions. Indeed, the overall trajectory of Thai politics and society has been toward greater polarization ${ }^{35}$. The reality of 11 Prime Ministers in the first 18 years of the $21^{\text {st }}$ century alone is a quick heuristic for understanding the Thai political system's chronic instability. The frequency of regime change and the corresponding splintering of the sangha into myriad factions and cults of personality makes a fully exhaustive study of both the Thai political system and sangha impossible in a single chapter. Instead, what follows is a study of the relationship between the state and sangha through five distinct time periods, beginning with a quick overview of early state formation. The analysis then shifts to the period of World War II (1941-1945) occupation. The second part of the case study takes a closer look at the long period of military rule (1948 to 1973). The third section follows Thailand's short-lived transition to constitutional democracy during the mid-1970's followed by the resumption of authoritarian rule through the 1980's and 1990's. The final section traces the rise of populism in the 2000's and its corresponding impact on the Thai monkhood.

\footnotetext{
${ }^{35}$ Political polarization in Thailand has taken different forms over the decades. The most prominent split was initially between royalists vs. anti-royalists, right wing vs. left wing, and populists vs. the establishment.
} 


\section{Thai State-Building and Sangha Politics (1868- 1941)}

From the $19^{\text {th }}$ century onward, the Thai state has served as a strategic buffer between rival powers. During the colonial era, Thailand was recognized by western powers as a demarcation zone between British Burma and French Indochina. Adept at playing major powers off one another, the Thai monarchy strategically ceded territory in the south and east as a means of avoiding direct colonization (Owen 2005, 96-97). The absence of an exploitative colonial regime permitted the Thai state to expand and modernize during the $19^{\text {th }}$ century in ways that British Burma and French Indochina could not. The growth of the Thai state was also facilitated by its instrumental use of Buddhist ideology employed with the purpose of purifying and integrating co-religionists in the northeastern part of the country.

In the meantime, the Thai monarchy engaged in a process of internal expansion spreading the language and customs of Bangkok to tribal areas on the periphery. As with nation-building initiatives in Europe, the largely successful process of internal colonization contributed to the growth of the state's power (Wyatt 2003, 186). Under the leadership of King Chulalongkorn (1868-1910), a western-style civil bureaucracy emerged, with the sangha enveloped under the formal organizational control of the state. The Sangha Act of 1902 rationalized monastic organization, placing the institution under the leadership of a royally appointed administrator, the Sangharaja ${ }^{36}$. In the interest of maintaining close control over the sangha, the king appointed his younger half-brother to

\footnotetext{
${ }^{36}$ The Sangharaja, which literally translates to the King of the Monkhood, has an association with premodernity in Thailand. For a more in-depth study of the traditional relationship among the Thai monarchy, Sangharaja, and society see Tambiah, Stanley (1976).
} 
serve in the role of Supreme Patriarch, a decision which further fused the monarch's right to rule with his role as protector of the national religion (Ishii 1986, 68). Doctrinally, Chulalongkorn had pushed for a more conservative interpretation of Theravada Buddhism, purified from the "superstitions" that had crept into Thai Buddhist practice over the centuries.

Chulalongkorn's "rationalized" version of Buddhism, while thoroughly modern in outlook, exacerbated an ancient schism between two major Theravada traditions (Thammayut and Mahanikai) which still has salience in contemporary Thai Buddhism. At the turn of the $20^{\text {th }}$ century-despite or perhaps as a reaction to-the monarchy's hegemonic power exercised over the official sangha-dissident religious traditions emerged. The extension of a new taxation system and modernized bureaucratic administration disrupted traditional means of economic exchange in frontier areas and took power out of the hands of local administrators, particularly in areas like Chiang Mai in northern Thailand (Owen, 103). In short, conflict on the borderlands stemmed from the direct encroachment of the Thai state into territories that were previously tributary in nature ${ }^{37}$. Higher taxes demanded by the Thai government, and the undermining of local Lao tribal leaders in the northeast led to a series of rebellions (Murdoch 1967, 55). Resistance to inclusion culminated in a series of rebellions among the followers of charismatic monks who amalgamated Buddhism with traditional spirit-worship. Perhaps the most noteworthy of these conflicts was The Holy Man's Rebellion transpiring during the years of 1901-1902

\footnotetext{
${ }^{37}$ Unlike neighboring Burma, the Thai state has not faced widespread ethnic conflict outside of the south. The successful assimilation of ethnic minorities into the state also speaks to its greater relative coercive capacity.
} 
(Ibid, 57) During this time, myriad religious movements operating in a space outside the formal state religion, such as the ascetic forest monk tradition led by figures like Ajan Man, were eventually co-opted by the state apparatus (Swearer 1999, 203).

During the early part of the $20^{\text {th }}$ century, the Thai state-building project accelerated under the watchful eye of Chulalongkorn's successor King Vajiravudh. Apart from tremendous growth in the state-bureaucracy, The Thai state's encroachment into northern Thailand's formally autonomous kingdom of Chiang Mai were accompanied by missionary ventures designed to incorporate tribal peoples into the state's form of Theravada Buddhism (Keyes, 1971). Meanwhile in Bangkok, rising political tensions contributed to the overthrow and abdication of the Thai monarchy in 1932. In what would prove to be a harbinger of future military interventions in Thai politics, a coup group took power. The coup leaders, though anti-royal in spirit, were not liberal democrats, as General Phibul and his associates shared a fondness for the Fascist ideology of Germany and Italy of the 1930's (Hewison 1997, 12). While a general elite distaste for the monarchy dominated the pre-World War II era, royalists also made their opposition visible through frequent protests. Political battles, pitting supporters of the monarchy and military against one another were prominent though short-lived, as the two institutions would eventually reconcile upon the King's return to Thailand.

The liberal impulse, or at least rhetoric of the period, contributed to a corresponding change in the structure of the official state sangha. In the interest of building greater accountability and responsiveness between the top rung and lower administrative organs of the state sangha, the 1941 Sangha Act created the "separation of 
powers" at the top of the national hierarchy (Keyes, 1971, 560). The original position of the Sangharaja, created during the 1902 Sangha Act, was eliminated in favor of a council system built on the principle of consensus (Jackson, 1989, 64). While lofty in principle, in practice, the new Sangha Act only created greater distance between the competing Thammayut and Mahanakai sects. Over time, the smaller, but more influential Thammayut sect, (originally patronized by the monarchy) gained influence over the decision-making process and would go on to absorb the lion's share of state patronage (Suksamran 1982, 44). The formal institution of the sangha and the spirit of Thai Buddhism would be tested during Japan's invasion in 1941, as the latter sought to remold Thai society in its image.

Thai Buddhism: War and Strategic Alliance Building (1941-1962)

During the period of Japanese occupation, Thailand made a series of concessions to the invading army with the hope of avoiding the destruction transpiring in other parts of Southeast Asia. The Japanese war effort in Thailand was fought on both the military and ideological battlefield. As was the case in neighboring Burma, the Japanese authorities did not merely attempt to control territory, but also sought to actively mold Thai Buddhism into a caricature of the Japanese Zen tradition. In return, the Thai wartime government reluctantly permitted Japanese Buddhist monks to reside in Thai Theravada monasteries. On the intellectual front, Byoto, A prominent Japanese-Buddhist scholar and apologist for the Japanese war effort took charge of the religious propaganda task through the distribution of writings translated into the Thai language (Ford, 19). Ostensibly, Byoto's aim was to encourage quietist monks to become more actively involved in 
political affairs through direct participation in the war effort (Ibid, 17). Yet, the cultural gulf between the Japanese Zen and the Thai Theravada traditions was too dramatic for the Thai occupied government to assent to. Quiet and active resistance to the conversion project built as the Thai regime began to see Japan's chances of wartime victory diminishing. By 1944, as the Japanese war effort in Southeast Asia stalled in Burma, the Thai government strategically shifted its allegiance to the allies. This turned out to be a momentous decision, as Thailand would prove to be an important strategic partner in the west's Southeast Asian containment strategy.

After the war, Thailand became a key linchpin in U.S. Cold War strategy, strengthened by the return of Phibun to the role of Prime Minister (1948-1957). Internal political rivalry led to General Sarit's (1958-1963) decisive coup, bringing Thailand even closer to the west. From 1951 and 1957, Thailand received \$149 million in economic aid and $\$ 222$ million in military aid from the United States. (Wyatt, 262). The politicization of the sangha intensified during the 1950's under the leadership of Sarit. Under his rule, the Thai state and society took a right-wing approach to politics. The democratizing impulse, which led to the restructuring of the state sangha in 1941, had all but completely evaporated under the Sarit regime. Eager to re-establish more direct regime control over Buddhism, Sarit adopted a $19^{\text {th }}$ century approach to the management of organized religion. Corresponding political pressure on the sangha culminated in the Thai government's 1962 Sangha Act.

According to the 1962 arrangement, the king acts as the Protector of Buddhism and appoints a Supreme Patriarch (Sangharaja) to administer the sangha. Under the 
Supreme Patriarch resides the Council of Elders, who are appointed for renewable twoyear terms. Under the Council of Elders are a series of regional and provincial councils, with members subject to approval from superior councils. At the bottom rung are 300,000 or so ordinary monks. The explicitly hierarchical structure is based on supervisory power and state regulation while the government provides stipends for all members of the bureaucracy at the district level or higher (Suksamran, 49-50). Today, the contemporary structure of the state sangha, which very closely approximates its 1962 design, is based upon a system of formal and informal promotion, whereby regime loyalists are often rewarded with high-ranking positions.

Under the leadership of General Sarit, the sangha was tightly supervised. Somboon Sukramsan writes that Sarit's cabinet, "passed a resolution to expel monks who expressed opinions that undermined the healthy condition of the religion and that were opposed to government policies" (Sukramsan, 59). This is not to say that important resistance figures weren't also part of the national political conversation. Phimondham, a high-profile monk who had supported democratization within the sangha administrative structure represented a source of energetic power outside of Sarit's control (Swearer, 2010). The widely publicized trial of Phimondham under the pretense that they harbored communist sympathies (Ford, 99) and other likeminded monks likely did lasting damage to the military regime's image among the Thai people.

Sarit's promotion of state Buddhism went beyond his predecessors, as Thai Buddhist missionaries, sent on behalf of the state, "educated" rural villagers in neighboring Laos and Thailand. As early as 1959, Harry H. Pierson notes "the continued 
evidence of the policy of the Department of Religious Affairs to promote the Thai branch of Theravada Buddhism in other countries" (Pierson, 1959). This observation is reaffirmed by Eugene Ford, who argues that U.S/Thai political cooperation during the Cold War contributed to the "internationalization" of Thai Buddhism (Ford, 9).

The return to a more hierarchical administrative rule, formally created in 1962, only enhanced the power of more traditional elements in the sangha, linking them even closer to the monarchy and the Sarit regime. The most prominent monks at the time cooperated willingly in the government's strategy of communist containment, including but not limited to rural development and education programs, surveillance of monasteries, and the defrocking of anti-regime monks (Swearer 1999, 212-214). The Sarit regime also featured highly prominent supporters among the sangha who led the way in cementing an alliance between the state, military, and sangha. One such figure, Khittivuddu, operating from his position in Chittapawan college, trained roughly 3,700 monks by 1975 in the Programme for Spiritual Development. Benefitting from access to state patronage and the use of government sponsored radio, Khittivuddu became an indispensable figure in the military regime's own anti-communist political agenda (Suksamran 75-77). Khittivuddu went so far as to exclaim in one of his teachings that "killing communists is not demeritorious" for Buddhists (Swearer 2009, 214).

The repressive military dictatorship under Sarit and his successor General Thanom Kittikachorn, encountered a crisis of legitimacy during the early 1970's as the Thai economy was beset by high levels of inflation. The resulting economic crisis, widespread in its impact, combined with high levels of political repression led to 
dwindling popular support for the military regime (Suksamran, 64). High-profile monks who did not cooperate with the regime were subjected to threats and more formal means of intimidation. Despite these reprisals, several monastic organizations appeared during the 1970's, voicing both their disapproval of the regime and a decidedly left-wing orientation toward labor and peasant reforms.

Relative authoritarian stability under military rule, was interrupted by a series of student-led protests in 1973. Under the direction of King Bhumibol, high-ranking military generals were asked to leave the country, ushering in a brief period of parliamentary democracy. In 1976, the king controversially invited a former member of the military Junta back into Thailand to be ordained as Buddhist monk, sparking additional protests and police crackdowns in Bangkok. The crisis of 1973 led to a fierce rivalry between establishment monks and reformists content on making contemporary Thai Buddhism relevant to the emerging middle class (Jackson 1989, 121). In this pursuit, several prominent reformist monks linked Buddha's teaching to democratic principles, while rejecting the more metaphysical side of the religion espoused by traditionalists (ibid).

This turbulent democratic period in Thai history (1973-1976) was characterized by more space for leftist mobilization. Consequently, in this short time frame the number of labor unions and corresponding strikes increased, as did newspapers and pamphlets espousing a range of leftist sentiments from Fabian Socialism to Marxism. In this period of crisis, monks also became highly politicized. Somboon Suksamran writes, "At the leftwing political meetings, demonstrations, rallies, and protests-which in most cases 
involved criticism of government-several groups of monks were seen to be observing the events" (Ibid, 83). Monks also participated in large-scale peasant rallies, even making speeches (Ibid 105-107). Apart from democratizing Thai society, and creating more just socio-economic structures, the monks of the left also called for changes in the sangha hierarchy.

The efforts of leftist monks to gain greater influence was met by harsh reprisals from the Thai state. To further marginalize the leftist position, the Thai military sponsored their own brand of right-wing political monks, who among other things, attempted to discredit socialism as a foreign ideology alien to true Buddhist teachings. In this respect, socialism was considered not only to be un-Buddhist but also un-Thai. In cloaking Buddhism in the Thai national identity, right-wing monks like the aformentioned Kitthiwuttho heightened the atmosphere of threat posed by leftists in Cambodia, Laos, and Vietnam. The campaign was largely successful. During the Cold War, the hierarchy within the Thai Sangha sought to maintain its relevance in society. "With the Thammathut and Thammacarik programs of the mid-1960's, the Thai monkhood had been made an instrument of government policy, enabling the clergy's further polarization. (Ford, 231). In the 1970's, “events showed that Thailand's clerical leadership would now tolerate political activity, provided that it was supportive of establishment conservatism" (Ibid, 255).

In cases where the Thai military are actively challenged by monks, it has sought to protect pro-government monks. The double-standard applied to the prosecution of monks charged with violating the vinyana (or monastic code of conduct which calls for 
monks to remain politically quiescent), is reminiscent of other cases in neighboring Burma and Laos, where only monks who espouse an ideology contrary to the regime are considered "political monks".

The legacy of student and monastic crackdowns during the 1970's, in concert with the political polarization of the sangha, did irreparable damage to the reputation of both the military regime and the state sangha. This is particularly evident in cases where Thai monks could be relied upon to support crackdowns. Perhaps unsurprisingly, the official state sangha's relevance has dwindled over time. Duncan McCargo, in detailing the capture of the sangha by the state argues, "The general direction of Thai politics from 1973 onwards was toward greater pluralism and liberalism, but Buddhist thinking played a surprisingly small role in these developments, most of which occurred with little input from the orthodox sangha, (McCargo 2004, 158). Instead, the sangha has been perceived by many Thai citizens as a "gerontocracy of narrow-minded elite monks preoccupied with defending their own interests" (Ibid 2009, 5).

With the continuation of authoritarian rule into the 1970's and 1980's, the sangha administration maintained its close relationship to the state. However, several rival groups emerged in response to government corruption questioned the legitimacy of the sangha administration. Concurrently, environmental monks, socially engaged monks, and evangelical monks all carved out space in Thai civil society. While these groups often attracted international attention and support, they were not free from government cooptation. In one instance, forest monks in Northeastern Thailand cooperated with the Thai government to fence off land from ethnic Hmong villagers (Keyes 1999, 23). 
One of the most prominent and controversial groups, Santi Asoke, which practices an ascetic form of Buddhism, saw its leader Bodhiraksa defrocked for allegedly causing divisions within the Sangha (Swearer, 223). In opposition to the newer variants of Thai Buddhist practice, the state cultivated linkages in certain high-profile monasteries. The Prathum Thani and Dhammakaya monasteries stand out as one of these state-supported monasteries. In part, many of the more esoteric religious movements stemmed from popular frustration over the intimate financial relationship between Buddhist temples and the state. Even in the 1990's, when the official form of Thai state Buddhism has been challenged by splinter movements, Buddhism is still appropriated by the state as a functioning governing ideology. Peter Jackson noted, "Buddhist concepts and arguments no longer constitute the core of Thai discourses on the right to govern, but judicious and timely recourse to Buddhist ritual and doctrine can still bolster governments and the careers of politicians (Jackson 1997, 85).

Additionally, the Thai state stepped up its defense of its preferred version of Buddhism against perceived challengers. Duncan McCargo writes, "The Thai state has arrogated unto itself the right to decide what constitutes 'correct' Buddhism-and through other mechanisms, has sought to similarly regulate both Islam and Christianity" (McCargo 2009, 7). This role is particularly evident in Southern Thailand, where the state has traditionally stepped up missionary activity to regulate both Buddhism and Islam (Ibid).

Since the 1990's the Thai state has adopted a narrower focus on punishing individual monks for their failure to comply with the rules of monastic discipline 
(Jackson 1997, 80). In this respect, successive Thai governments have likely come to the realization that the sangha is splintered beyond repair and consequently, the Thai government has been more selective in implementing patterns of cooptation and coercion. High-profile scandals involving the personal misconduct of monks have recently drawn widespread media attention, forcing the sangha administration to act. Phra Buddha Issara, who took up a prominent role during the 2014 pro-democracy protests, was arrested in a wide-ranging sweep of Thai monasteries upon allegations of sexual misconduct and financial impropriety (Irrawaddy.com). An upsurge in coercive tactics against monasteries has been the hallmark of the current military government geared toward enhancing the prestige of Thailand's sangha.

The Wat Phra Dhammakaya, a controversial monastery, known for its unorthodox teachings, has been deeply enmeshed in a network of questionable sponsorships. Highly connected to Buddhist clubs at Thai universities, the temple also has strong links both to Thai corporations and the bureaucracy (Dubus, 44-45). Despite the temple's strong deviation from traditional Theravada teachings, including promises of rebirth as millionaires for large scale donations, the temple has not been sanctioned by the Supreme Sangha Council (Ibid 49). The Thai police raided the temple in 2017 under the pretense of investigating corrupt practices, though likely targeted the monastery's chief abbot for his connection to the Red Shirt ${ }^{38}$ political movement (Styllis and Tongfueng 2017).

\footnotetext{
${ }^{38}$ The Red Shirts are a left-wing populist movement formed after 2006 to challenge the military regime. In elections, they have supported Thaksin and his sister, Yingluck Shinawatra.
} 
If the Thai political system is characterized as a series of shifting and informal personal networks linked through the monarchy, military, and civilian bureaucracy (McCargo 2005) then high-profile monks have traditionally been adept at working within these networks to access patronage resources. However, as the political balance of power shifts quickly in Thailand, monks and monasteries once favored by the government can be subjected to coercive tactics, as is the case with the Wat Dhammakaya.

In the post-cold war era, Thailand oscillated between military dictatorship and brief periods of civilian rule. Street protests and a violent government crackdown in 1992 ushered in the return of civilian leadership, under the center-right Democrats and the conservative Chart Thai party. The democratic optimism of the 1990's was eventually superseded by the populism of Thaksin (2001-2006), followed by the return of military rule in 2006. The growing polarization in Thai society throughout the 1990's and early 2000's was reflected in the sangha as well. Under the populist Thaksin Shinawatra regime, Red Shirt rallies and protests prominently featured monks. In the previous decade, prominent supporters of Thaksin among the ascetic Santi Asoke movement shifted allegiance after the latter's policies became more free-market oriented (Swearer, 34)

The division of the sangha along political lines, "red shirts" (pro-labor, agrarian) versus "yellow shirts" (conservative royalists), while socially important, has not resulted in any weakened capacity on the part of the state to effectively regulate religion. In Thai politics, two important institutions (the monarchy and military) have not served as neutral arbiters between conflicting parties. Prior to the 2010 street protests, the state put 11 
monks under surveillance, including the heads of two prominent Buddhist universities in Bangkok, under suspicion of supporting the Red Shirts (Dubus, 38)

During an era of increased polarization, allegiance to the Thai state has been most prominently displayed in the south, as an ongoing conflict between Thai and Malay nationals has, at times, solicited direct participation from the Sangha. As Michael Jerryson (2011) observes, the traditional separation between monks and soldiers has broken down in southern Thailand with the growing militarization of temples. The ethnic divide has also been used instrumentally, as Thai Princess Sirikit has called on Buddhists to defend their religion on the southern border through her missionary Volunteer Monk Project. Jerryson writes, "These cultural ambassadors are more than links between the State and localities; they also act as embodied representations of the State and Thai Buddhism" (Jerryson 2011, 67).

Though political society in Thailand features a high degree of elite fractionalization, as exemplified by the sheer number of 19 attempted and 12 successful coups in modern history, the state's bureaucratic/administrative capacity has remained high over time. In addition, the state has been able to successfully employ coercive strategies, (i.e. raiding of monasteries, defrocking of "political monks") effectively. By and large, the long-term success of co-optation strategies has meant that the coercive approach has been used far less frequently than in neighboring Burma.

\section{Malaysia}

In Malaysia, a far more ethnically heterogenous state than Thailand, the fusion of Islam and Malay ethnicity has been a defining feature of the state's post-independence 
political reality. The rise of Malay nationalism, and the corresponding UMNO's (United Malays National Organization) grip on power $^{39}$, has resulted in two important phenomena that differentiate Malaysian politics from the Burma and Thailand cases. In one respect, Islam has been the state religion in Malaysia since 1957, thus giving successive Malaysian regimes the formal legal justification to patronize and regulate their preferred version of Sunni Islam. In a related sense, it has provided the same regimes with power to delineate the rights and privileges of Muslim vs. non-Muslim citizens. Secondly, Malaysia has developed both coercive and bureaucratic/state capacity at levels that dwarf Burma and even Thailand. The long-term pattern of sustained economic growth in Malaysia, provides the state with another pillar of legitimacy, but also a far more developed and sophisticated authoritarian toolbelt. In direct contrast with Burma, whose authoritarian system has been extraordinarily durable yet unstable (Slater and Fenner 2001) and Thailand which oscillates between regime types, Malaysia's own brand of authoritarianism is well entrenched.

Unlike Thailand, the politics of Malaysia have been characterized by an orderly succession of power. Also, unlike Thailand and Burma, Malaysia's hegemonic party initially came to power through the democratic process. Slater observes that Malaysia's strong and durable state is a result of a long history of strong party rule insulated through a civilianized bureaucracy (Slater 2012, 21-24). In this respect the dominant UMNO (United Malay National Organization) has shown flexibility in its responsiveness to

\footnotetext{
${ }^{39}$ The UMNO has ruled Malaysia since independence in 1957. Only recently (2018), did the Prime Ministership shift to another party, with the return of former Prime Minister Mahathir Mohamad to power.
} 
citizens, while creating authoritarian institutions that make it almost impossible for a party outside of the coalition to take power.

Instability in government, when it has arisen, results from internal party conflict rather than mass contentious politics. The rotating inclusion and exclusion of political rivals under the umbrella of the UMNO's Barisan National Alliance, Malaysia's largest party, has occasionally led to dramatic confrontations on the national political stage. Specifically, the entrance and exit of the PAS (Islamist) opposition, and frequent power disputes between the Prime Minister and Deputy Prime Minister's office have put strain on the UMNO-led alliance. The most public of these disputes involved the sacking of former Deputy Prime Minister Anwar Ibrahim by current Prime Minister Mahathir under charges of sexual impropriety and corruption. The detention and bearing of Ibrahim by the Malaysian security forces were more likely a result of the former's desire to supplant Mahathir as Prime Minister during the 1990's (Verma 2002, 145). The most recent firing of Najib Razak under similar charges, culminating in the restoration of 92-year-old Mahathir returning as Prime Minister in early 2018, perpetuates the historical pattern of intra-party, inter-personal rivalries.

The ostensible role Malaysian citizens have played in the ouster of specific Prime Ministers is deceptive, as the UMNO regime has deftly used the superficially democratic institutions of the state to maintain its grip on power ${ }^{40}$. While the outcome of specific elections in post-independence Malaysia have at times been uncertain, throughout

\footnotetext{
${ }^{40}$ Steven Levitsky and Lucan Way identify Malaysia as a "competitive authoritarian" regime, whereby the UMNO creates an "uneven playing field" for political opposition (Levitsky and Way 318-28).
} 
modern history there were very few instances in which the dominance of the UNMO was ever significantly threatened. Despite the occasional reshuffling of elites, the long rule of the Malay majority party has in part resulted in a specific approach to the state management of religion.

As the overall post-independence trajectory of Malaysian politics has been characterized by relative stability, what follows is an analysis of the state and religion in five chronological periods. First, I will briefly explore this relationship during the colonial period (1795-1957). The second part of this case study closely focuses on the rise of Malay political power during the post-independence era under the rule of the first Prime Minister Tunku Abdul Rahman (1957-1970). The next section examines Malaysian society under Abdul Razak Hussein and Hussein Onn (1970-1981). The fourth part shifts focus to the long rule of Mahathir Bin Mohammad, (1981-2003). I conclude with an examination of the state and religion in Malaysia from 2003 to the present.

The State and Islam in Malaysia: The Colonial Era

Malaysia's Islamic identity dates back far before the arrival of the European colonial powers. Islamic traders from the Arabian Peninsula and India beginning in roughly the $12^{\text {th }}$ century set up merchant exchanges in both the peninsula and Borneo. Later colonization by the Portuguese, Dutch, and British, led to increased demand for laborers and colonial bureaucrats. Well before the $20^{\text {th }}$ century, Malaysia's multi-ethnic, religious diverse society was cemented through large-scale South Asian and Chinese migration. Extractive economic activities, including the establishment of tin mining operations, led to the immigration of between 20,000 and 30,000 Chinese immigrants 
into the Malay straits settlements between 1850's and 1872 alone (Owen, 143). By 1891, Malays in the federated Malay states composed only 53 percent of the total population (Ibid, 147).

Apart from massive demographic shifts, the British policy of divide and conquer altered the traditional balance of power in both the peninsula and Borneo. While village tribal leaders were often marginalized by the British, the Malay upper-class and regional indigenous leadership profited under the colonial administration (Ibid, 145). The British dependence on imported labor from South Asia and China was not without important political consequences. The ethnic tensions underlying Malaysian politics during the $20^{\text {th }}$ century is in part a consequence of the large-scale societal disruption initiated in the $18^{\text {th }}$ and $19^{\text {th }}$ centuries.

In short, each ethnic group sought refuge in its own political party, with ethnic Malays coming to numerically dominate the country. The ethnic balance of power was guaranteed upon Singapore's eventual exit from the Malaysian federation in 1965. During the British colonial era, the practice of Islam was tolerated though certainly not favored. Apart from setting up missionary schools, and spreading Protestantism throughout the colony, the British sought to centralize and control the practice of Islam. In 1879, the first Islamic magistrate became an employee of the British colonial bureaucracy, ushering in a new era of rationalized religious hierarchy in Malaysia (Lee and Ackerman, 33). The British, as elsewhere in Southeast Asia often promoted ethnoreligious minorities, appointing South Asians to high ranking positions in the colonial 
bureaucracy and cooperating with the Chinese resistance during the Japanese invasion of Malaysia.

The State and Islam in Malaysia: Independence to the 1970's.

Patterns of social disruption under colonial rule stoked the flames of Malay nationalism during the early $20^{\text {th }}$ century. Lee and Ackerman (1997) write, "The significance of the colonial period for Malay ethnicity lies in the introduction of a foreign bureaucratic machinery that was meant largely for the administration of the colony, but in the process of administration provided an organized means for the definition of Malayness...." (Lee and Ackerman 1997, 33). Highly educated Malay officers and bureaucrats would come to spearhead the Malay nationalist movement, leading eventually to the formation of the UMNO.

The UMNO began as a secular organization, internally conflicted on Islam's role in a future independent country. During Malaysia's transition to independence, intra-elite competition was a contributing factor in the state's eventual Islamic orientation. The UMNO founded in 1946, prior to its dominance over the Malaysian political system, faced an existential crisis over the role of Islam in the country's future. The avowedly secular leadership cadre, spearheaded by Abdul Rahman, were particularly cautious to not alienate British leadership, who were unlikely to accept anything but a moderate secular government upon their departure (Liow 2009, 22).

During the 1940's and early 1950's, several major political factions competed for future political control. The major socialist party MNP (or Malaysian Nationalist Party) eventually split over ideology, with some prominent party members defecting to the 
(MCP) or Malaysian Communist Party. The MNP formed an offshoot Islamic party known as Hizbul Muslimin which sought to create an independent Islamic state, noting their frustration with the UNMO to not directly sponsor their vision of the proper role of Islam in Malaysia. In the interest of settling the proper role of Islam within party ranks, the UMNO sponsored their own Islamic party conference in 1950. Many of the members present at that conference eventually defected from the organization to form the PAS (Parti Islam se-Malaysia), Malaysia’s main Islamist opposition party (Ibid, 23).

The MNP came under significant pressure during this period as their close association to the Malaysian Communist party instigated UMNO and British crackdowns during the first "Emergency" period beginning in 1948. Patterns of internal conflict, both violent and non-violent have pushed the UMNO from an outspoken secular organization to the widely acknowledged representative and promoter of Sunni Islam in Malaysia. During the 1950's the UMNO began to consolidate their power across the peninsula. Forming a coalition with the major Indian and Chinese parties (MIC and MCO) respectively, the UMNO sought to bring all potential rivals into a single alliance, even incorporating rival PAS into the Barisan National in 1974. The control of the UMNO over this process was especially pronounced during this period. As Harold Crouch (1996) notes "While the alliance could have been characterized as a partnership (although an unequal one), the BN was in fact a façade for UMNO rule. Nevertheless, it provided machinery for consultation and representation" (Crouch 1996, 34). Despite the multiethnic nature of the political alliance, Malay identity is strongly linked to Islam and has a historical social class basis in rural Malay identity. 
Like Thailand, the Malay state's coercive apparatus was strengthened during the Cold War. During the first "Emergency" period (1948-1960) the state expanded its reach into previously autonomous regions of the state under the pretense of rooting out communism. The resulting violence, which had a strong ethnic dimension, (most of the state's alleged communist sympathizers were ethnic Chinese), did not lead to a protracted conflict as in Burma or Southern Thailand, but rather to a Weberian monopoly of violence over state territory. As Dan Slater (2012) notes in his study of Malaysia and Singapore, "By the early 1950's, both British colonies had literally become police states, with effective civilian institutions of coercion to bridle endemic communalism and leftist radicalism" (Slater 2012, 20)".

The Chinese riots of 1969 led to a stronger consolidation of state coercive power as well, though the state's strategy toward ethnic minorities changed over time, from one of persecution in the 1950's and 1960's to greater formal political and economic accommodation. Oscillations in the UMNO's approach to ethnicity and religion, do not appear to be a part of a long-range strategic plan. Rather, as Harold Crouch argues the UMNO's position on ethnic questions has been contingent on the politics of crisis aversion (Crouch, 96). In the interest of keeping their fragile political coalition together, the UMNO has crafted more conciliatory policies toward Chinese and South Indian minorities, particularly after 1969 . Conversely, when the party believes it is alienating its 
political base it pursues policies designed to either materially or symbolically appeal to the Malay majority ${ }^{41}$.

Throughout the 1970's, the UMNO engaged in several political purges designed to maintain their hegemonic position in Malaysian politics. Elite level conflict returned during the 1970's as new Prime Minister Abdul Rezak clashed with former Prime Minister Tunku Abdul Rahman. Around the same time, the PAS was formally expelled from the Barisan National culminating in the UMNO led government initiating a state of emergency in Kelantan State, where the PAS had ruled since 1959 (Ibid, 104). David Camroux (1996) convincingly argues that the foray into Kelantan state was part of a broader "carrot and stick" strategy whereby the BN sought to split PAS leadership in Kelantan as a pretext for taking control of the state government in the interest of restoring “order". (Camroux 1996, 860)

The State and Islam: 1980's to the Present

Unlike Thailand or Burma, the Malaysian state does not have an explicit organization devoted to the supervision and regulation of its clergy. Instead, the ulama (religious scholars) form the traditional basis of religious authority among Muslims across Malaysia. The Malay administration of Islam occurs on both the federal and state levels. At the federal level, the Islamic Affairs department and Federal National Council of Islamic Affairs work in tandem with the states to administer Islam. While federal and state regulation of Islam are technically separated in the constitution, the federal

\footnotetext{
${ }^{41}$ This strategy was employed during the 1980's, as Prime Minister Mahathir brought a series of Islamist leaders into the government, in an effort to dilute the power of rival PAS.
} 
government has frequently intervened in the states when it perceives important interests at stake. Islamic administration on the state and local levels is subject to differing interpretations of Sharia law. Lee and Ackerman write, "The departments of Islamic affairs (Jabatan Agama Islam) in every state are the chief instruments of administrative and moral control (Ackerman and Lee, 39).

The state's approach to religion has also evolved over time to accommodate domestic pressures and potential electoral challengers. While it wouldn't be entirely accurate to claim that the state has become more "Islamic" over time, it has more effectively used the institutions of the state to marginalize pressures emerging from perceived social threats. At first, government fears centered around the combined influence Chinese and South Asian minorities on the national distribution of political power. In a similar way, the UNMO were cautious about Islamic revivalism, and its potential sway among ethnic Malays, particularly in poorer rural areas. As a partial solution to their ethno-religious concerns, the UMNO has made extensive use of gerrymandering, whereby traditionally loyal states have received greater political representation than their population numbers would justify. Of the Malaysian electoral system, Graham Brown (2005) writes, "Constituencies were to be determined on the principle of the equality of size, but a rural weightage of up to two times were allowed." (Brown 2005, 5). Under this arrangement, rural areas, dominated by ethnic Malays, particularly on the peninsula have had greater representation in government thus limiting the influence of ethno-religious minorities centered in wealthier districts. 
Islamic revivalism in Malaysia began in earnest during the 1970's, first through the efforts of the PAS, and later initiated by the UNMO administered government under Abdul Razak and then Mahathir. Camroux argues that the Mahathir's approach to Islamic revivalism has been both proactive and reactive. In terms of curbing the appeal of Islamic revivalists, Prime Minister Mahathir first attempted to coopt the PAS party into government, while simultaneously constructing mosques, creating an Islamic Bank, and an International Islamic University in 1983 (Camroux, 858). Proactively, Mahathir attempted to link his brand of moderate Islam to a broader socioeconomic development narrative, thus hoping that a financially secure population wouldn't be swayed by more fundamentalist strains of Islam (Ibid).

Vidhu Verma argues that the tendency toward greater Islamization in the government was mostly instrumental, at least under the reign of Mahathir. Specifically, "In the 1980 's, Mahathir, along with other UNMO leaders, decided to meet the challenge of Islam by simply coopting influential opponents, opposition parties, and their ideas into government" (Verma 2002, 108). Mahathir's decision to bring noted Islamic revivalist, Anwar Ibrahim into government as his deputy Prime Minister was particularly influential (Ibid, 109). Though not an Islamist in his own right, Mahathir sensed that he was losing legitimacy in an era where the politics of religion, not just in Malaysia, but worldwide was gaining greater popular appeal.

The Malaysian government has also made frequent use of the Internal Security Act (now known as the National Security Council Act) as a means of cracking down on forms of religious practice it deems undesirable. The broad interpretation of the ISA to 
encompass any relevant threats to security or economic life has resulted in its implementation against prominent religious and political figures alike (Human Rights Watch 2004). As a complementary strategy, the state under the supervision of Deputy Prime Minister Anwar Ibrahim created opportunities for previously hostile supporters of the PAS to join the state religious bureaucracy (Camroux, 860). In maintaining strong linkages and surveillance on Islamic student organizations at Malaysian universities, the UMNO has been able to forestall the development of student-led protests. When necessary the UMNO has also resorted to coercive force against its perceived enemies.

The constantly expanding religious bureaucracy enforces the Ahlus-Sunnah Wal Jammah form of Islam, Malaysia's traditional variant of Sunni Islam. A such, Shi'a Islam and Sufi Islam have been subjected to persecution (Mohamad 210, 518). This process is not without contestation, as the Malaysian middle classes have gradually pressed for more pluralistic forms of Islam (Ibid, 523). Mohamad writes, "The state pushes for more laws, regulations and stipulations on homogeneity in order to govern the Muslim subject more definitively and less ambivalently" (Ibid). In the first the case, the state has used the courts and legislature to put a halt to Christian and Buddhist evangelization. Specifically, Malaysia has made it illegal for non-Muslims to proselytize to Muslims, while the same restriction does not apply to Muslims.

While non-Muslims are not permitted to be tried in Sharia courts, certain courts have sought to overturn that ban (Lee and Ackerman, 41). Related, the state enforces conversion bans for Muslims seeking to leave their faith and puts additional restrictions on inter-faith marriages (Mohamad, 378). Movements the state deem as unorthodox have 
also come under significant pressure in recent decades. Specifically, supporters of the AlArqam sect and Anti-Hadith movement have been subject to government harassment (Ibid, 50-51).

The state has also been sensitive to challenges emerging from local Islamist politicians and preachers who view Malaysia's current way of managing religion as accommodationist; meaning that it has not done enough to push for the establishment of Sharia law. The tensions between state and society are apparent, as the UMNO has sought a difficult balancing act in terms of maintaining its position among religious moderates and hardliners alike. Argues that bureaucratic centralization in the religious bureaucracy advanced authoritarianism from the 1980's forward. Kikue Hamayotsu (2002) observes, "the concurrent process of institutionalizing the state Islamic administrative apparatus involved the incorporation of an increasing number of government-employed ulama into the formal state structure. The expanded state religious bureaucracy came to regulate and further restrain free and diverse religion-related activities or expression in society" (Hamayotsu 2002, 15).

The reach of the state into the management of religion in Malaysia has only expanded over time. According to Erik Martinez (2001), surveillance of religious teachers in government-funded Islamic schools are commonplace. Officials from the government routinely visit mosques to verify that the state-approved sermon is delivered (Martinez 2001, 482). The government has also extended control over state-level ulama, as the $\mathrm{BN}$ controls most state-level governments in Malaysia (Ibid, 479). On the individual level, worshippers who are said to stray away from what the government has 
deemed as the appropriate form of Islam are subject to punishment which varies from state to state. In the state of Perlis, individuals are subject to detention in "Faith Rehabilitation Centers" (Ibid, 482). While in other states, non-Christians have complained about the allocation of land for churches and corresponding burial grounds (Ibid).

Apart from the growth of the religious bureaucracy and its influence on both the federal and state levels, Malaysian regimes since Mahathir's first term in office have sought to position themselves as the rightful guardians of Malay Islam. Through extensive public education initiatives through the lavishly patronized Malaysian Institute of Islamic Understanding think tank, the Malaysian state attempts to marginalize Islamist opposition (Hamayostu, 357).

Synthesizing State Capacity and Religious Organizations in Thailand

In tracing the evolution of the State/Sangha nexus in Thailand, analysts have preferred to showcase its transformation through distinct episodes. In his work, Donald Swearer refers to four chapters in the evolution of the State/Sangha relationship in Thailand (Swearer 1999, 224). First, under the rule of Chulalongkorn the sangha was purified and revitalized to represent the monarchy's favored brand of doctrinally and socially conservative Theravada Buddhism. Second, a united Sangha was created to better integrate the burgeoning modern Thai-nation state. This process accelerated during the first half of the twentieth century and culminated in the Sangha Act of 1962. The third chapter relates to the fusion of Buddhism and the nation into a form of civil religion. The Cold War exemplified this new development as Thai Buddhism came to symbolize an 
important conservative bulwark against communism in neighboring Laos and Cambodia. The latest chapter, according to Swearer, refers to the exploitation of the sangha for specific political purposes.

While this account provides a useful guide to understanding how the Thai state has appropriated Buddhism since the late $19^{\text {th }}$ century, it implies a certain singularity of purpose which fails to address complex and shifting networks of political access. Though the Thai state is strong compared to neighboring Cambodia and Laos, its effectiveness in regulating the sangha is in part hamstrung by a long-term pattern of political instability. During periods of crisis, individual monks and new Buddhist religious movements operating outside the mainstream of Thai Buddhism have implicitly and explicitly challenged the state. In this respect, while an overall orientation toward monastic cooptation has been accompanied by occasional crackdowns, it is not accurate to say that any Thai regime has exerted sustained control over the sangha. As has been the norm in its political system, the sangha, outside of the upper echelons of the state apparatus, remains deeply fractured. In this case, it is not only the strength/weakness of the state, but rather the unpredictability of the political system which has provided new spaces for dissident monks to operate.

The Thai state features a highly sophisticated military emerging out of decades of Cold War financial support from western powers. The modern Thai state experienced a booming post-World War II economy. Economic development from 1963-1973, was mainly technocratic and top-down in nature. Charles Keyes (1986) writes "This asymmetrical relationship in the development process caused no concern insofar as the 
populace accepted the "experts" as being agents of a government which ultimately depended on the approval of the king and that king reigned because he had the necessary "merit and virtue" (Keyes 1986, 131).

During the 1960's and 1970's, buoyed by extensive western aid the Thai state ratcheted up its export economy, while simultaneously bolstering domestic demand for imports. As in Malaysia, the Thai state used their position as a strategic player in the US cold war containment strategy to extend their reach more deeply into the provinces. By the 1960's Phongpaichit and Baker observe that "For the first time, villages were regularly visited by officials-by the nai amphoe-district officer, by police, by military officers, and by representatives of various ministries" (Phongpaichit and Baker 75). This greater administrative reach coincided with the Sarit regime's use of missionary monks to forestall the appeal of communism in rural Thailand.

It would be an overstatement, however, to suggest that the Thai bureaucracy has been strictly technocratic in the modern era. Extensive political networks, particularly between corporations and the military flourished during the Sarit era, reinforcing crony capitalism. Big business in Thailand has been particularly adept at negotiating the treacherous waters of Thai politics. Provincial business interests played an important role in the rule of pluto-populist Thaksin (2001-2006), while the military carefully aligned itself to commercial business interests in the post-cold war period (Phongpaichit and Baker, 341).

The overall capacity of the state has remained high by regional standards across time despite frequent regime change. Over the past several decades, MK Connors (2009) 
convincingly argues that fragmented elites have sought to shape the Thai state in their own image. "Contending regime framers seek to embed specific patterns of political power that reflect distinct social bases articulated to state apparatuses" (Connors 2009, 356). More specifically, Connors argues that elites compete for control of the Thai state, through distinct persuasions: liberal, statist, and plutocratic (Ibid 356-358). The statist period, preeminent during periods of military rule, is characterized a strong highly centralized state fused with token appeals to democracy. Conversely, Thailand went through a brief period of liberalism during the 1990's, when elites sought to create a more democratic, responsive regime. This period was interrupted by the Asian financial crisis of 1997. Finally, the plutocratic period refers to rule under Thaksin, as Shinawatra and his cabinet sought to directly appropriate and control state resources for personal enrichment. In sum, the recurrence of military invention in Thai politics "indicates the fragility of constitutional order and the persistence of authoritarianism in the military and the palace" (Connors, 366).

The Thai state has alternately been characterized as a form of network politics (McCargo 2005) and a bureaucratic polity (Riggs 1966). In this respect, it is very difficult to draw clear delineations between the state, the capitalist class, and civil society. Instead, it is more expedient to think of politics in Thailand defined by elites competing for state access through a series of cross-cutting networks. When one sector is perceived by others as gaining too much power, the monarchy and/or military will typically intervene to reestablish control. This pattern of interaction isn't limited to periods of civilian rule, as a long tradition of counter-coups also exist to check the power of aspirational generals. 
In terms of bureaucratic capacity, the Thai state never fully adopted the economic model of East Asian “tiger” states. Phongpaichit and Baker remark, "Although Thailand lacked the strong state and industrial policy which characterized the developmental state in East Asia in this era, it achieved some of the same effects. The state was committed to 'development' which primarily meant fostering a domestic capitalism. With US technical assistance it ensured that labor was disciplined and prevented from developing any organizational power" (Phongpaichit and Baker 2002, 457). The 1960's and 1970's were also characterized by the development of a bureaucratic polity linking together the military with business interests. In terms of government effectiveness, Thailand has consistently ranked between 0 and 0.3 on Kaufmann and Kray's (2017) Government Effectiveness scale, ranking only behind Malaysia in terms of the cases surveyed in this dissertation.

According to the Association of Religious Data Archives, Thailand scores low on government regulation of religion and religious persecution (ARDA, 2017). It does score fairly high on government favoritism of religion. The lower levels of active persecution are indicative of a state with a high degree of bureaucratic capacity that does not have to rely on the regular use of force to keep members of the majority and minority religions at bay. The rather high level of government favoritism refers to the traditional financial and policy support for the official state sangha.

The overall trajectory of Thai state power has been one of growing bureaucratic and coercive power since the World War II period, and even earlier, to the late $19^{\text {th }}$ century. This case is easily contrasted with neighboring Burma, who has witnessed an 
increase in coercive power and a steady collapse of the civilian bureaucracy. In terms of state development this is not at all shocking, as the Thai bureaucracy, free from the exploitation of a colonial administration, was rationalized and expanded from the $19^{\text {th }}$ century forward. Yet, this explanation alone does not suffice, as Malaysia (the state featuring the strongest bureaucracy among the states included in this dissertation) did undergo a history of formal colonization. In this respect, regime responses to internal threats, frequent conflict in Burma during early independence. Thailand's emergency response to the spread of Communism mattered. In the first case, the civilian bureaucracy in Burma was never sufficiently developed prior to independence, in fact it faced almost total collapse during world War II, thus making the military the only viable institution. Preoccupied with maintaining their privileged place in Burmese society, the military competently siphoned off economic resources as a means of entrenching their rule. In Thailand, a functioning domestic civilian bureaucracy survived the Japanese occupation, through a series of compromises negotiated by Thai leadership with the Japanese while its coercive apparatuses were strengthened through massive aid inflows during the Cold War.

Though bolstered by their strategic position during the Cold War, Thai state capacity did not meet the expectations of sanguine economists who predicted in the 1970's and 1980's that Thailand would join the ranks of Asian tiger economies like South Korea and Singapore. Instead, elite competition over resources drove a wedge in the development process. As a country, Thailand ranks moderately high on both bureaucratic/administrative and coercive power, yet features a political elite engaged in perpetual conflict over access to state resources. 


\section{Synthesizing State Capacity and Islam in Malaysia}

In the successive decades, a booming economy, bolstered by exports and the banking sector further enriched the state. Ethnic favoritism in economic matters extended through the 1960's and 1970's with the creation of the New Economic Policy which among other things sought to bolster the economic status of Malays, while curbing the traditional economic power of the Chinese diaspora community. The long-term goal of the NEP was to transfer corporate wealth and ownership from the Chinese and Indian ownership to the rising Malay middle class. While the NEP hasn't met its lofty goals, it has dramatically changed the relevant social position of ethnic Malays (Camroux, 854).

In recent years, Malaysian regimes have reformed economic policies to have a less punitive impact on non-Malays. From the 1990's onward, widespread state intervention in the economy was substituted for the National Development Policy (NDP). The new policies, accompanied by aspirational development goals, privatized industry and sought to attract foreign capital. (Verma, 152).

In terms of its bureaucratic/administrative capacity the Malaysian state dwarfs Thailand in terms of its government effectiveness (Kaufmann and Kray, 2017) An overall pattern on consistently high levels of government effectiveness has held since the first data point in 1996. As for coercive power, Malaysia's military, while numerically smaller than Thailand and Burma's, requires the same percentage of GDP expenditure as Thailand (World Bank, 2016).

Malaysia's shift from Import-Substitution Industrialization to an export driven economy bolstered by large scale industrialization in the 1980's has led to the creation of 
wealth unmatched by even Thailand. High levels of GDP have been used by the state to bolster its bureaucratic and coercive power arms. The frequently cozy relationship between state officials and the finance sector, while leading to high profile corruption charges, has largely insulated the UMNO from electoral threats.

In terms of its approach to religion, Malaysia's score on the Association of Religious Data Archives "government regulation of religion" indicator is high at 7.9/10, showcasing the state's prominent role in enforcing its preferred variant of Islam on Malaysian society while its level of religious persecution is moderate, and on par with Thailand and Vietnam (ARDA).

\section{Conclusions}

The contrasts in the Thai and Malaysian cases are indicative of their different historical state development trajectories. Thailand's progressive state capacity development dates to the $19^{\text {th }}$ century, whereby a process of internal colonization enhanced both the coercive and bureaucratic/administrative capabilities of the state over time. Its strategic management of external threats, at first balancing the British and French colonial interests off another, its cooperation with the Japanese during World War II spared the country much of the destruction witnessed in other parts of Southeast Asia. Finally, its Cold War alliance with the United States and allies resulted in massive foreign investment, further enriching the state. 
Despite its early modernization initiatives and the absence of formal colonial rule, elite political fragmentation and shifting alliances between the military, monarchy, and civilian political leaders has contributed to a chaotic political history, featuring 19 attempted coups. Thailand's relationship with the sangha has also vacillated across time. During the immediate post-war period and throughout the Cold War, the sangha by and large was a reliable partner in the state's internal battle against communism. Leftist monks were in the minority and were often subject to state harassment or arrest. Corresponding to patterns of political fragmentation, the sangha has also become more divided over the past several decades. Pro-democracy monks active in the 1970's along with monks who broke away from the official state sangha to form their own associations were poised as new threats to state legitimacy. The polarization of the 1990's and early 2000's, corresponded with certain monks aligning themselves with the relevant "Red Shirt" and "Yellow Shirt" political movements.

In the $21^{\text {st }}$ century, with the restoration of military rule, the sangha remains divided. More importantly, the official state sangha has lost a great deal of popular legitimacy plagued with corruption and sex scandals, along with cases of richly patronized and highly commercialized variants of Buddhism. While the state continues to exert its influence on the sangha through patronage and occasional crackdowns on "deviant" monasteries, it does appear as though maintaining the legitimacy of the sangha is no longer a top priority for the state. Instead, its overarching concerns hinges more on socioeconomic development than standard appeals to religiosity. 
The power of the Malaysian state is evident through the hegemony of a single party, the UMNO. From the late colonial period, through the immediate postindependence era the UMNO emerged as the best organized party in Malaysia, inheriting the colonial bureaucracy created by the British; a bureaucracy that for geopolitical reasons was far more developed than the one left to Burma in the 1940's. The UMNO's dominance of the political system and the economy accelerated through the 1960's and 1970 's, as the country became a major economic powerhouse in Southeast Asia. Though autocratic, the Malaysian state is perhaps the preeminent example of a competitive authoritarian system whereby political pluralism exists, though on an uneven playing field (Levitsky and Way 2008). The Malaysian state's influence over the media is one such example of this phenomenon. Since the 1980's the three major parties of the Barisan National Alliance own virtually all daily newspapers, while all radio and tv is owned directly by the state or its affiliates (Means 1996, 110).

Unlike its authoritarian counterparts in Burma and Thailand, Malaysian authoritarian regimes have largely avoided engaging in hard crackdowns against opposition (Case 2009, 312). Instead, they have relied heavily on the politics of patronage. Ethnic cooptation targeted at Malays has been a recurring theme during the post-independence era. However, this does not mean that Malaysian regimes have not also deployed coercive force when deemed necessary. Under the pretense of the Internal Security Act, the Malaysian police has remained unflinchingly loyal to the state and have engaged in violent crackdowns against political opposition (Slater 2003, 95). However, I argue that these measures have been employed by the regime as a secondary strategy. 
Yet, it is patterns of cooptation have characterized the relationship between the state and Islam. The state's preferred brand of moderate Islam has been promulgated through active control and patronage of mosques and Islamic universities. Student associations have also been folded into the state's central religious bureaucracy. When the regime has felt under threat from Islamist challengers, it has invited them into government as was the case with Anwar Ibrahim. The state's divide and conquer approach to religious challengers is evident in relations with the main Islamist challenger party, the PAS. While regimes have resorted to coercion at times, including sending "deviant' practitioners to re-education centers, its control over religion in Malaysia on the state and federal level means that widespread conflict between Islamists and the state has been nonexistent, unlike neighboring Indonesia and the Philippines.

The UMNO, in managing ethnic and religious differences through patterns of control and accommodation has continually adjusted to internal threats to its rule. The state's own ethnic patronage system balanced with strategic outreach to Chinese and South Indian communities has evolved over time. Though class, ethnic, and regional tensions certainly exist in Malaysia it is highly unlikely that these will threaten the hegemony of the UNMO and its management over state resources.

The following chapter will take a closer look at variations in the authoritarian management of religion across the nominally Marxist states of Cambodia, Laos, and Vietnam. Despite sharing a similar ideological commitment to the marginalization of organized Buddhism, patterns of gradual accommodation in Vietnam are juxtaposed against cases of hard repression in Laos and Cambodia. 


\section{CAMBODIA, LAOS, VIETNAM}

Organized religion in the region formally known as French Indochina has weathered significant threats to its survival. The violent $20^{\text {th }}$ century in Southeast Asia, marked by World War II, also featured a bloody civil war in Laos (1970-1975), genocide in Cambodia (1975-1979), and two major wars in Vietnam (1946-1975). These conflicts unleashed unimaginable horrors on civilians and religious organizations alike. In part, French colonial rule, uneven in its influence across Indochina, created conditions favorable to the outbreak of political violence. Specifically, the French, rather than relinquish their colonial possessions after the defeat of Japan in World War II, held on for an additional 9 years, with the direct effect of further agitating and emboldening the colonial resistance.

What distinguishes political developments in French Indochina from the British colonies of Malaysia and Burma was the nature of the resistance itself. Marxist insurgents in Vietnam, Cambodia and Laos presented a particularly persuasive argument concerning the brutality of French imperialism ${ }^{42}$. As such, communist guerillas succeeded in recruiting a sizable percentage of their respective populations. For opponents, the Viet Minh, the Pathet Lao, and the Khmer Rouge mobilized the military resources required to stifle dissent. While communist groups were active and organized in Vietnam, Laos, and Cambodia before the French exited the region in 1954, American involvement in the

\footnotetext{
${ }^{42}$ While communist insurgents were active in Burma and Malaysia after World War II, they had significantly less popular appeal in these countries and were largely seen by the population as foreignsponsored agitators.
} 
region during the 1960's and early 1970's unintentionally legitimized Marxist resistance as the only entity capable of countering foreign aggression.

Spillover from the Vietnam War, most notably America's extensive bombing along the Ho Chi Minh Trail in Cambodia and Laos facilitated Khmer Rouge and Pathet Lao recruitment efforts respectively. Importantly, for the purposes of this research, the Buddhist sangha in both countries were directly affected by the political turmoil of the post-WWII period. From the near destruction of organized Buddhism in Cambodia, to the irreversible politicization of the sangha in Laos, the place of religion in these two countries was forever altered by civil war.

In Vietnam, a country at war for much of its modern history, Viet Minh resistance to French colonial rule in the north was validated after the defeat of the latter at Diem Bien Phu in 1954. From that point forward, the communist advance, temporarily stymied by American military intervention in the 1960 's, posed a significant territorial threat to South Vietnam after the 1968 Tet Offensive. The final siege of Saigon and unification of Vietnam in 1975 inexorably changed the nature of the regime/religion nexus.

As the focus of this chapter is on the post-World War II relationship between states, regimes, and organized religion in Cambodia, Laos, and Vietnam, I do not intend to provide a comprehensive historiography of the region in this chapter. Instead, I will focus more narrowly on how variation in state capacity endowment shaped the strategies Marxist regimes in each of the three countries have employed against organized religion. As such, the chapter proceeds as follows. The first section provides a brief overview of the pre-colonial period and French colonial rule and its management of organized religion 
in Cambodia, Laos, and Vietnam. The second section traces the relationship between authoritarian regimes and organized Buddhism in Cambodia from 1945-present. Parts three and four analyze the same phenomenon in Laos and Vietnam while the final section focuses on state capacity development in the region and provides some concluding remarks on the contemporary implications of authoritarian governance for religious actors in the region.

\section{Politics and Religion in Pre-Colonial Indochina}

Just prior to European arrival, the territory that forms the modern states of Indochina differed greatly in terms of political and religious tradition. Vietnam, though nominally-independent from foreign rule, had endured nearly 1000 years of Chinese direct rule, and then Sino cultural and political influence for several hundred years following. In the early $19^{\text {th }}$ century, Vietnamese politics was dominated by powerful clan-based rule. Administratively, North Vietnam was more centralized than the south, having inherited a Confucian-style bureaucracy and civil service system adopted from China. Milton Osborne (2013) notes, that unlike other Southeast Asian states, the Vietnamese system sought to regulate political affairs in a hierarchical top-down system descending all the way to the village level (Osborne 2013, 45).

South Vietnam, by contrast, had been influenced more by Cambodia's tributary political system. As such, villages were administered through looser patron-client relations. In terms of ethno-religious diversity, South Vietnam's Mekong Delta region was populated not just by ethnic Vietnamese, but sizable Khmer (Cambodian) and Cham Muslim minority groups as well. In fact, large tracts of land in the delta region once 
belonged to the Cambodian monarchy. In terms of religion, Confucianism, Taoism, Mahayana Buddhism, Catholicism, animist and syncretic traditions all hold significant influence in Vietnam to this day.

While Vietnam is traditionally a majority Buddhist country, the Catholic minority ${ }^{43}$ advanced politically and culturally during the French colonial period. While Catholics received the freedom to practice their religion freely after formal colonization, they were also viewed by non-Christians as "serfs of the French" (Gheddo 1970, 23). In more general terms, religious practitioners in both North and South Vietnam borrowed and blended elements from different traditions, blurring traditional theological boundaries ${ }^{44}$. During the colonial period, the European obsession for scientific classification, accompanied by the political utility of pitting indigenous groups against one another, hardened religious identities in Vietnam.

Cambodia, in terms of governance, shared much in common with the Theravada Buddhist traditions of neighboring Thailand. Khmer ${ }^{45}$ influence in Southeast Asia peaked during the Angkor period ( $9^{\text {th }}$ century to $15^{\text {th }}$ century C.E) and retracted in the centuries prior to the arrival of the French. From the $16^{\text {th }}-18^{\text {th }}$ centuries, Cambodia's territory was consistently threatened by the Thai and Vietnamese. As such, Cambodian royals alternately payed tributes to both kingdoms in the hopes of forestalling its absorption into

\footnotetext{
${ }^{43}$ Catholics, though only composing 10 percent of the population, held disproportionate political influence in Vietnam during the colonial and immediate post-colonial eras, particularly in the south.

${ }^{44}$ It is not uncommon for Buddhists in Vietnam to also incorporate beliefs borrowed from Taoism, and traditional animism into their practice.

${ }^{45}$ The Khmer are the largest ethnic group in Cambodia. The country is roughly 80 percent Khmer and 80 percent Buddhist.
} 
these territories. During the $20^{\text {th }}$ century, Cambodia continued to face military threats from both neighbors.

Lacking a centralized bureaucratic/administrative system prior to French colonization, the foundations for a modern Weberian state in Cambodia were less promising than in Thailand or Vietnam. Instead, policies were dictated through patronage (Dell, Lane, Querebin 2015, 6). Unlike Thailand, Cambodia in the $19^{\text {th }}$ century could not embark upon extensive state-building efforts as the royal family was subject to the whims of the French colonial administration. In contrast to Vietnam, Cambodia had never developed a top-down bureaucratic system capable of collecting tax or providing services outside of a very narrow geographical area.

In Cambodia, as in Thailand, precolonial kings claimed otherworldly authority resulting from a favorable Karmic rebirth. Similarly, Cambodian kings lavishly patronized favored sangha sects. Ian Harris writes, "In Phnom Penh, close proximity to and familiarity with the Court, or more recently with the apparatus of government, has meant that the Buddhist hierarchy has customarily manipulated, or at least been forced to accommodate itself to, prevailing currents of power" (Harris 1999, 54). As in Thailand, Theravada Buddhist monks were split along the Thommayut and Mohanikay factional lines. Upon the arrival of the French, via Vietnam, Prince Norodom requested that Cambodia become a French protectorate in 1863 in large part to protect it from Thai encroachment to the west. Osborne observes, "The decision of the French in Vietnam to extend control over Cambodia beginning in the 1860's may be seen as ensuring the state's survival" (Osborne 2013, 79). 
Laos in the $18^{\text {th }}$ century was a loosely organized territory with three competing seats of political power based in Vietntiane, Luang Prabang and Champassak respectively. The mountainous and rugged Lao terrain made it the most isolated region in Southeast Asia, though its precolonial borders stretched well into modern northeast Thailand. Like neighboring Cambodia, Laos was created as a viable state by the French authorities. Eager to create a buffer zone to halt British advance from Burma, the French colonial power advanced in 1885 to establish a new state (Osborne 2013, 80).

The royal families of each of the three principalities all claimed to operate with divine sanction, administering different territorial units. Conflicting political loyalties were exacerbated by the colonial authorities, who sought to parse out Lao ethnic identity from upland tribal groups. The effort to create a true "Lao" identity continues to this day (Holt 2009).

Featuring an incredibly diverse population, only roughly 60 percent of the population identifies as Lao, while the remainder belong to an assortment of different ethnic groups (Evans 1998, 2). While Laos is a majority Theravada Buddhist country, animist traditions, often fused with Buddhism, have a strong influence on the Lao culture. The prevalence of animist spirit "cults" became a point of contention during the French colonial period and the post-independence era. The French, and the post-independence Marxist Lao People's Revolutionary Party, shared a common commitment toward eradicating animist practice in Laos. 


\section{Politics and Religion in Colonial Indochina}

The French arrived in Vietnam during the 1830's and moved to colonize Cambodia and Laos in the 1860's and 1880's respectively. French strategic interests in the three territories differed, as Vietnam was of principal interest for its proximity to the Chinese market. French interest in Cambodia was initially sparked by archeological curiosity in the ruins of the ancient Angkor Empire (Owen 2005, 121). However, it also appealed to the French for its economic potential and a desire to counter Thai influence in the region. Laos itself, traditionally composed of tributary states loyal to Thailand and Vietnam was purposely created as a state by the French, who viewed it as a necessary buffer against Thai encroachment. Cambodia, though itself more of a viable nation than Laos, also lacked clearly defined borders, which became a significant point of contention for much of the latter half of the $20^{\text {th }}$ century.

Upon the arrival of the French, direct efforts to convert large numbers of Cambodian Buddhists to Catholicism were not pursued as in neighboring Vietnam. Instead, the French authorities largely viewed Buddhism as having an innocuous effect on the population. While the French did not prohibit Buddhist practice, they did put limits on monks traveling outside of Cambodia and restricted the number of new monasteries that could be built (Harris 1995, 56). The French plan in Cambodia was to "rationalize" Cambodian society, purifying traditional Buddhism from superstition with the support of the monarchy.

Administratively, the reigning monarch Prince Norodom (1860-1904) created a national sangha organization in 1880 and appointed a Mohinikay monk to the head 
administrative post (Ibid). Monastic political activism was marked by three significant events. First, in 1855-56, a large-scale revolt erupted against Norodom, followed by a series of peasant revolts during the 1920 's. During the early part of the $20^{\text {th }}$ century, monastic political activism was fueled after the founding of the Institute Bouddhique, an organization dedicated to promoting Buddhist culture (Owen 2005, 364). This initiative was initially sparked by French interest in ancient Cambodian Buddhist manuscripts, but also had the unintended consequence of galvanizing a renewed sense of Khmer nationalism among Buddhists. Despite this fact, the Cambodian nationalist movement in organizational size and scope paled in comparison to the Viet Minh.

For much of the colonial era, Buddhists in Cambodia remained politically quiescent as compared with their neighbors in Vietnam. The political instability of the 1930's and 1940's did lead to one transformative moment: the 1942 "Umbrella War". Featuring large numbers of protesting monks, this movement was mainly a reaction to the growth of the French educational system, which had curtailed monastic educational duties (Harris 1999, 59). During the Japanese occupation, Cambodia had been ruled indirectly through the French Vichy government until 1945. In 1943 and 1948 the sangha was reorganized, with the French authorities and monarchy alike concerned about the infiltration of Marxist ideology and practice in the sangha. After World War II, and the Japanese occupation, the French authorities refused to abandon their colonial possessions in Indochina. Instead, Cambodian Prince Sihanouk, who would singlehandedly dominate the country's politics for the next half century, negotiated a timeframe for independence, which quickly accelerated after the defeat of the French military at Diem Bien Phu, 
Vietnam in 1954. While Prince Sihanouk would indeed lead his country to independence, he was unable to manage the chaos which eventually led to the rise of the Khmer Rouge.

In Laos, the French governed much as they did in Cambodia, though the complex ethnic composition of the former made this arrangement even more tenuous. The French decided to administer their rule through the contemporary capital of Vientiane, though as mentioned earlier, precolonial Lao royal authority was split into three separate geographic regions. The French supervision of monarchs in Luang Prabang and Champassak did much to delegitimize royal ritual power (territorially, the French reduced the overall size of Laos in 1907, redrawing the demographic map and incorporating more members of upland minority groups). As Grant Evans (1998) keenly remarked, "how does one legitimately claim to be a king or prince of a ruling house under foreign colonial rule?" (Evans 1998, 90). The reality is that the French were not particularly concerned about ritual politics, but instead sought to modernize Laos as part of their broader Mission Civilisatrice.

Like Cambodia, France maintained a light administrative footprint in Laos, preferring to rule indirectly through Vietnamese bureaucrats. Of the colonial era, Kingsbury (2005) writes that the French had conquered Laos but had almost no practical use for it. As such, "Infrastructure was almost non-existent and economic development continued at a very low level" (Kingsbury 2005, 176). Under French rule, as in Cambodia, the traditional education system was nominally reformed to emphasize secular instruction. Yet, despite pretenses to the contrary, the French failed to invest substantial resources in education (Holt 2009, 83). 
Buddhism in Laos prior to French arrival was highly decentralized. During the French occupation, the colonial regime had the twin goals of modernizing Buddhist practice, while purging it of Thai influence (Ibid, 96). During the colonial period, according to Martin Stuart-Fox, "French rule effectively eliminated any political influence for Buddhism in Laos" (Stuart-Fox 1999, 154). Despite this fact, many monks did play a significant role in Lao Issara or "Free Laos" independence movement. Holt writes, "the agitations led by the sangha for political independence signaled a re-entry into the public political culture of the country" (Holt 2009, 101). The reassertion of French rule after World War II radicalized some nationalists who had looked at the success of the Viet Minh in Vietnam as a model for resistance. Moderates increasingly sorted themselves into two distinct camps, Royalist and Pathet Lao (Marxist).

Within the fractured post-World War II Lao political scene, most monks initially opposed both secular elites in Vientiane, and the Pathet Lao rebel group: the former for their alleged moral decadence, the latter for their Marxist ideology. This pattern changed during the 1950's, as the Pathet Lao, a full partner in coalition government, exercised more direct control over religion in Laos. Post-1958 communists in Laos actively recruited monks, while agents within the Thai government and U.S CIA sought to limit communist infiltration into monasteries (Ford 2017).

In Vietnam, as mentioned previously, clear divisions in practice between Buddhism and other religions were not always apparent ${ }^{46}$. This is not to say that religious

\footnotetext{
${ }^{46}$ While religious syncretism in Vietnam has a long history, it should be added that most Vietnamese Buddhists belong to the Mahayana school, which tends to be less hierarchical than its Theravada counterpart.
} 
groups in pre-colonial Vietnam did not acknowledge theological divisions, but that the colonial experience made religious identity politically salient. Upon colonization, the French did not encounter a society on the verge of sectarian conflict, but rather one facing a crisis of leadership. During the early part of the $19^{\text {th }}$ century, from $1802-1840$, roughly 105 different rebellions against the emperor's court occurred (Tarling 1999,199) For most Vietnamese, the political connection between the royal court and daily existence was distant, except through a modern tax collection apparatus. Thus, the French colonial authorities could capitalize on political division and popular disenchantment with indigenous leadership to secure their rule. However, like colonial systems elsewhere, indigenous Vietnamese resentment to foreign rule morphed into direct political action. Meaningful resistance to the French authorities in Vietnam grew in momentum during the 1930 's through the growth of anti-colonial organizations, the most prominent known as the Viet Minh ${ }^{47}$.

Buddhist activism during this time period was as much about religion as it was about the lack of effective leadership from Confucian elites (Do 1999, 260). Buddhist leaders in Vietnam were motivated not just to rid themselves of the French, but also to craft a "modern" belief system purged of superstition. During the 1930's, three regional Buddhist Associations (Northern, Central, and Southern) united to achieve these goals with tacit French approval. By the 1940's, fearing the infiltration of radicals, the French moved to close these associations (Ibid, 266). While Buddhists took the lead in anticolonial agitation, other minority groups, including a sizable number of Catholics, also

\footnotetext{
${ }^{47}$ While the Viet Minh eventually became a front organization for Ho Chi Minh and his communist army, it was far more tolerant of Catholics and other religious minorities during the 1930's.
} 
pushed for independence (Gheddo, 27). Catholic relations with the Viet Minh deteriorated by the 1940's as the latter organization became more exclusively Marxist in orientation.

The resistance to the French in Vietnam was initially dominated by, on the one hand, nationalists who envisioned an independent, united, and democratic Vietnam, and on the other, Marxist revolutionaries pushing for comprehensive social revolution. While both groups were thoroughly secular, the Viet Minh, originally a fusion of nationalists and revolutionaries, took on a distinct Leninist identity by the 1940's. In the aftermath of World War II, the Viet Minh was winning the political argument, while actively recruiting a peasant army in northern and central Vietnam. Armed French forces failed to contain the spread of the Viet Minh, who by 1954 had not only mobilized large numbers of Vietnamese citizens, but also began initiating massive social and economic programs, including land reform (Beresford 1988, 28). In response, the French and their allies sought to shore up support in the south through a series of puppet regimes.

\section{Cambodia 1945- 1954: Anticolonial Resistance}

Resistance to colonialism in Cambodia occasionally took on a Buddhist character, but unlike Vietnam, it initially came from the right of the political spectrum and was thoroughly influenced by Thailand. The left in Cambodia struggled to recruit Buddhists, many of whom still supported the royalist political faction. Internationally, the Indochinese Communist Party, which was eventually replaced by national organizations, sought to infiltrate monasteries during the 1930's, but did not find a particularly receptive audience (Ford, 2017). This pattern did change after World War II as elites defected to 
the communist party with greater regularity. For example, former monk Son Ngoc Minh, a high-profile member of the colonial resistance who had played a central role in the 1942 Umbrella War, joined the Indochinese Communist Party (Harris 2005, 158). In 1950, the United Issarak Front (UIF), a Marxist-sponsored monk association organized the First National Congress of Khmer Resistance at a local monastery, where roughly 100 monks were in attendance (Ibid). By the early 1950's the UIF Monks association was present in twenty-four monasteries and claimed over 700 active members (Ibid, 159). In the early 1960's, Pol Pot and other party members gave speeches to monks and even cited the Buddha's teachings in support for their revolution (Ibid, 160). However, by the mid 1960's, his Communist Party of Kampuchea (CPK) was become more anti-religious and increasingly insular.

\section{Cambodia 1954-1975: Sliding into Chaos}

After leading his country to independence, Cambodian Prince Sihanouk abdicated the throne and formed the Popular Socialist Community. His decision would usher in a period of political chaos, characterized by varied resistance to his monopolization of political power. Archival research indicates that former U.S. Ambassador Philip D. Sprouse (1962) was not exaggerating when he remarked, "All real political power in Cambodia is in the hands of one man, Prince Sihanouk" (Sprouse 1962, 16).

The tumultuous politics of the immediate post-war period in Cambodia was also reflected in official policies toward religion after the departure of the Japanese and French. Buddhism was lavishly patronized through the restoration of the educational system under the supervision of the Ministry of Cults and Religious Affairs. During this 
time period, monastic schools were constructed along with a sizable number of new monasteries. Finally, the first Buddhist University in the capital, personally sponsored by Sihanouk, was built in 1959 (Harris 1999, 62). Of the Sihanouk era, Harry H. Pierson observed, "Buddhism is permitted to be used for political purposes only by Prince Sihanouk, and then usually to support one of the undertakings or goals of the Sangkum Party" (Pierson 1968, 15). Despite these efforts, official state resources allocated to the sangha in Cambodia remained low as compared with neighboring Thailand.

Throughout the 1960's, sensitive to political developments at home and in neighboring Vietnam, Prince Sihanouk attempted to strike a neutral posture between communism and capitalism, preaching his own form of Buddhist Socialism. In real terms, Sihanouk's rule was characterized by personalized rule, nepotism, and elite fragmentation. His economic policies, including the nationalization of Cambodian banks, led to disastrous economic consequences. Domestically, living standards declined. Only 35-40 percent of the population in 1962 was literate (Sprouse 1962, 3). Attempting to play rival cold war powers off one another, and insulate himself from domestic criticism, Sihanouk moved harder to the left by 1964, eschewing U.S. support in favor of a closer relationship with China. Yet, Sihanouk's maneuvering did not shore up political support from radicals, who had a very different vision for the future. Instead, Sihanouk's experiment with Buddhist Socialism was doomed to fail (Harris 1999, 62).

By the late 1960’s Cambodian politics was in a state of total disarray. Prince Sihanouk, seemingly detached from the political realities on the ground, resigned as Prime Minister and left for France to pursue his career in filmmaking (Chandler 1991, 
189). Incapable and unwilling to curtail the spread of communism in Eastern Cambodia, Sihanouk was replaced in 1970 by Lon Nol, a right-wing military general intent on restoring political order. In international terms, the United States began to lose faith in Sihanouk's political abilities and wanted a leader who would take direct action against communist agitators (Tarling 1999, 72).

Instead, Nol's hardline approach to dissidents, the Khmer Rouge, and Viet Cong incursions set the stage for a five-year civil war (1970-1975). Despite holding a different ideological disposition, Lon Nol remained loyal to the Prince in absentia. In the meantime, Lon Nol attempted to recreate the precolonial alliance between the ruler and sangha and had hoped that Cambodia could follow Thailand's lead in cultivating a monkhood loyal to the state. Specifically, Nol invited prominent Buddhist monks to "educate" citizens about republicanism through state-run radio. Nol also warned that the triumph of communism would lead to the destruction of Buddhism (Harris 1995, 63).

During the early 1970 's, monastic safety was under threat due to a combination of Khmer Rouge aggression, government attacks and U.S. bombing raids (Harris 2005, 170). At the time, a sizable number of monasteries were occupied by Khmer Rouge forces who effectively turned them into operation bases. By the mid 1970's, it was becoming clearer that the Cambodian government was losing the civil war both ideologically and militarily. In 1975, Pol Pot and the Khmer Rouge made their final advance into Phnom Penh and defeated remnants of the military government. The events that followed forever altered the course of Cambodian history, and the place of Buddhism in the state. 


\section{Cambodia 1975-1979: The Khmer Rouge Period}

Much has already been written concerning the genocidal behavior of the Khmer Rouge (Kiernan 1981, 1985; Cribb 2010). Any attempt to explain why the Khmer Rouge declared a total war on society cannot ignore the role of their ideology, which was consciously adopted to imitate China's Cultural Revolution. In fact, Pol Pot had visited China and was clearly shaped by Mao’s philosophy (Chandler 1991, 148-149).

Other approaches emphasize psychology, with Pol Pot's personal paranoia and delusions of grandeur playing a central role in explaining why he brutalized not just average Cambodians but also close associates within the Khmer Rouge (Chandler 1999, $152)^{48}$. Still other plausible explanations focus squarely on domestic politics in Cambodia, arguing that Prince Sihanouk's aloofness led to the rise of popular support for Marxist guerillas (Osborne, 1994)

These compelling explanations notwithstanding, the focus of this section is designed to explore how the Khmer Rouge viewed Buddhism in Cambodia, and the steps they took to bring it under their control. To the casual observer, Khmer Rouge violence, which resulted in the deaths of roughly 2 million Cambodians in four years (1975-1979), appears to have been rather indiscriminate. This claim is not entirely without merit, as many Cambodians were executed by the regime under mere suspicion of traitorous

\footnotetext{
${ }^{48}$ According to Chandler, Pol Pot lived in constant fear of assassination, and blamed his stomach problems on what he thought were cooks trying to poison him.
} 
behavior. Yet in other cases, violence was deliberately employed against Vietnamese and Cham Muslim minorities ${ }^{49}$, urban dwellers ${ }^{50}$, and- crucially-the Buddhist sangha.

With respect to Buddhism, the Khmer Rouge initially saw some utility in coopting Buddhist slogans and symbols to attract support from the traditional peasant population. Similarly, the Khmer Rouge also made some early distinctions between rural and urban monks, viewing the latter with considerably more suspicion (Harris 2005, 171). Yet, on the whole, Buddhism was viewed by the Khmer Rouge as a corrupting influence on the population. Hinton writes that the Khmer Rouge saw Buddhism as loathsome because it rationalized inequality by linking it to the doctrine of Karma (Ibid, 128).

Shortly after taking power, the Khmer Rouge had claimed that $90-95 \%$ of monks "disappeared" (Kiernan 2008, 100). Harris adds: "In its initial stages the persecution of Buddhism involved the intimidation and re-education of the laity resulting in a steady diminution of alms-giving, coupled with the relocation of monks to 'safer areas"” (Harris 2001, 74). The Khmer Rouge outlawed all religious practice, with defrocked Buddhist monks sent to agricultural collectives to work alongside other Cambodians. By 1975, virtually all monasteries were closed. Between 1975 and 1979, 63\% of monks were either

\footnotetext{
${ }^{49}$ The Khmer Rouge took a particularly brutal approach to groups perceived as foreign. Part of this was rooted in their racist vision for recreating an exclusively Khmer empire. Cham Muslims were directly targeted by the regime and were forced to renounce their religious beliefs.

${ }^{50}$ Ideologically, Pol Pot made distinctions between peasants and urban elites. Once the Khmer Rouge took control over Cambodia, the country was divided into separate administrative zones. Though conditions were deplorable across the country, so-called "new people" (urban elites), were relocated from Phnom Penh to northwest Cambodia and were treated with unusual brutality. In this region, rice quotas were the highest. Here, most Cambodians, unaccustomed to life outside of the city died from disease and exhaustion.
} 
killed by the regime or died from starvation. (Harris 1995, 66). Many more Cambodian monks fled the country, making the dangerous trek across the Mekong River into Thailand. By the time of the Vietnamese invasion in 1979, there were only around 100 ordained monks left in Cambodia (Ibid, 66).

By 1979, the Khmer Rouge leadership, plagued by paranoia, internal purges, and complete economic devastation were on the verge of collapse. At this time, Pol Pot grew increasingly fearful of a Vietnamese invasion. ${ }^{51}$ In response, he launched a pre-emptive attack into Vietnam which was met with a swift response. Pol Pot and the remnants of the Khmer Rouge were pushed into remote territory in western Cambodia, where they continued to fight a guerilla campaign against the Vietnamese until the late 1980's. Despite the Khmer Rouge's military defeat, they continued to play an important role in the country's politics well into the 1990's ${ }^{52}$.

Cambodia 1979-present: Vietnamese Occupation and Personalist Rule

Following the Vietnamese invasion in 1979 and its subsequent indirect rule of Cambodia for over ten years, the relationship between successive regimes and organized Buddhism went through significant changes after the genocide. Despite the widespread destruction of Buddhist culture during the Khmer Rouge period, Buddhism has endured as an important source of legitimacy for rulers. Alexandra Kent (2006) writes, "In

\footnotetext{
${ }^{51}$ Pol Pot expected retribution for his annihilation of the Vietnamese community in Cambodia and harbored a long-held distrust of Vietnam.

${ }^{52}$ Current Cambodian Prime Minister Hun Sen is a former member of the Khmer Rouge
} 
Cambodia, power is still conceived as dwelling in the Buddhist pagodas, and access to such power is a necessary component to political survival (Kent 2006, 35).

During the Vietnamese era (1979-1989), there was a clear attempt on the part of the occupying regime to coerce Khmer Buddhism to serve their political goals. While monks were originally required to carry ID cards, engage in agricultural work, and support the stated goals of the regime, roughly 3000 monks were ordained in the early 1980's, and 700 new pagodas were constructed (Harris 2001, 75). Specifically, the Vietnamese regime immediately appointed seven top Khmer monks to bolster their legitimacy among a skeptical Cambodian public (Kent, 353). Additionally, while monasteries in Cambodia traditionally represented an autonomous zone free from direct state intervention, the Communist Party of Vietnam (CPV) and the Cambodian People's Party (CPP) have co-opted rituals such as the consecration of monasteries through ostentatious displays of generosity and public piety (Ibid, 365). In personal correspondence with Professor Erik Davis at Macalaster College, he revealed that the PRK period was a "period of restriction, surveillance, and suspicious control of the sangha." (Davis 2019).

Sensing an opportunity to contain the impact of Vietnamese influence in Cambodia, Prince Sihanouk entered a coalition with former members of the Khmer Rouge and other Anti-Vietnamese parties during the 1980's. Politically, the Vietnamese governed through the PRK (People's Republic of Kampuchea). At this time, the Vietnamese sought to reunify the broken sangha, through re-education programs. Administratively, Vietnam appointed the Ven. Top Vong to head the sangha. While this 
move represented a renewed tolerance for Buddhism in Cambodia, it was viewed skeptically by many Cambodians who felt that Vong would only serve the interests of the CPV. In 1985 Hun Sen, a former member of the Khmer Rouge, took power, a position he holds to this day. In 1989, beginning with the gradual Vietnamese withdrawal from Cambodia, Prime Minister Hun Sen publicly apologized for 'mistakes' toward Buddhism, and public officials began to patronize Buddhism through pious acts (Harris 2001, 76)

Following the departure of the Vietnamese, the United Nations sponsored Peace Accords (1992) resulted in a shaky political alliance between Royalists, the Vietnamesesupported Communist People’s Party (CPP), and former Khmer Rouge affiliates. Once this government collapsed, Hun Sen reasserted his power in Cambodia and moved to make Buddhism the official state religion. As part of this initiative, the Sen regime sponsored the creation of state Pali Language schools and a new Buddhist Institute. (Ibid, 70). This is primarily done to solidify Hun Sen's personalist base of power through patron-client relations (Davis 2019).

While Hun Sen's rule has been characterized by a gradual liberalization of religious restrictions, he has not hesitated to crack down on religious figures. Sen and his security apparatus violently attacked monks protesting fraud in the 1998 elections resulting in the shooting deaths of several young monks (Kent 2006, 356). Massive electoral violence also erupted during the 2003 elections, with the regime engaging in large-scale voter intimidation efforts (Sullivan 2016, 215). More recently, Buddhist monks protesting land reform have been threatened by the regime with banishment from the order or arrest (Chandran 2017) Less overtly ideological in his approach than his 
predecessors, Hun Sen's rule is deeply personalistic, relying on strong-man tactics. In the leadup to the most recent elections, Sen threatened widespread violence if he was not reelected to office (Pettit, 2018)

\section{Laos 1945-1975: Ideological Polarization}

Following Japanese defeat in World War II, and the French reconquest in 1946, some official changes were made with respect to the treatment of organized religion in Laos. The 1947 constitution identified Buddhism as the official religion of the newly unified state. While this decision appealed to the lowland Buddhist constituency, it was a point of contention for upland groups who continued to practice traditional folk religion. From 1947 to independence in 1953, Buddhism experienced a resurgence with the official number of monks growing to 13,500 (Stuart-Fox 1999, 156). In the meantime, battles for territorial control between the Royal Lao Government (RLG) and the Marxist Pathet Lao (Neo Lao) insurgency raged on, culminating in a military stalemate by the early 1950's.

In 1957, three years after independence, a provisional government was formed uniting the Royal Lao government with the Pathet Lao. Critically, it was at that time that the sangha underwent significant politicization (Holt 2009, 112). The Pathet Lao members in the coalition government exercised control over the Ministry of Religious Affairs and instituted a whole set of changes designed to simultaneously indoctrinate monks in leftist ideology, while also curbing their ability to exercise religious freedom. Of that period, Stuart-Fox (1999) remarks "Moreover, as anyone could become a monk, the Pathet Lao could easily infiltrate the sangha to propagate its message of 'true' 
national independence and anti-imperialism (aimed by then primarily at the United States" (Stuart Fox 1999, 156). These developments did not go unnoticed by the Thai authorities and American intelligence services. In the late 1950's the United States stepped up efforts to re-educate Buddhist monks in Laos, even funding the travels of prominent Thai monks into Laos for reeducation seminars (Ford, 2017 140). One of the unintended consequences of American/Thai involvement was the growing perception among Lao monks (as articulated by the Pathet Lao) that they were merely the objects of foreign indoctrination.

Despite their avowed Marxist loyalties, the Pathet Lao eagerly attempted to ground their appeal to Buddhists in overtly religious terms. Gard (1958) observed, "Whatever success the Neo Lao has had or did have among Lao Buddhists is probably chiefly due to their demonstration of interest in Buddhist customs, beliefs, conditions and aspirations" (Gard 1958, 10). Unlike clumsy attempts at Buddhist/Socialist fusion in Burma and Cambodia, the Pathet Lao were highly successful in convincing citizens that the two philosophical approaches could co-exist in harmony.

Internal political difficulties eventually led to the collapse of a provisional government in 1958, which was quickly replaced by an anti-communist regime intent on using the monkhood to advance their own political agenda. Under the new regime, monks were required to carry id cards, faced travel restrictions, and were more carefully chosen for monastic exams through a new administrative arrangement (Stuart-Fox, 157). At the same time, monks were deliberately encouraged to practice the more traditional/conservative Thammayut sect of Buddhism (popular in Thailand). In fact, 
development projects undertaken by the right-wing government were designed for specific political ends. The move toward a more "socially-engaged" Buddhism sponsored by the RLG and USAID was cynically designed to deter peasants from joining the Pathet Lao (Evans 1998, 56). After a short-lived coup in 1960, and a reassertion of anti-communist politics, political and religious conservatives faced more backlash from monks sympathetic to the Pathet Lao cause. ${ }^{53}$

In 1962, the Geneva Accords formally recognized Laos as a neutral party in the Vietnam War. On the ground, Lao society moved along a path of irreversible polarization. At this time, the Pathet Lao continued to receive more support from rural monks, many of whom came from poor backgrounds. Rural engagement was in some measure based on economic grievances, but also a popular perception that elites in Vientiane had become too westernized, and consequently decadent. Monasteries in the countryside became sites for political activism, with the Pathet Lao sending out monks to preach on the compatibilities between Buddhism and Marxism (Stuart-Fox 1999, 158).

In 1966, Buddhism became the official religion in Laos. However, despite organizational pretenses to the contrary, official linkages between the state and the sangha were not particularly strong. Harry H. Pierson observed, "There is no more tradition for a centralized sangha in Laos than there is for a unified government

\footnotetext{
${ }^{53}$ Curiously enough there was no clear break between the monarchy and the Pathet Lao communist forces. Compared with neighboring Thailand, where the royal family has been reliably conservative in its politics, what transpired in Laos more closely resembles developments in neighboring Cambodia. In Laos, Prince Souphanouvong also referred to as "The Red Prince", sided with the Pathet Lao insurgency. The fusion of royal power with the Marxist insurgency afforded the Pathet Lao greater popular legitimacy.
} 
structure" (Pierson 1966, 8). Yet, Pathet Lao efforts to infiltrate the sangha remained strong during the 1960's. Holt observes that even though the Pathet Lao were working to ideologically co-opt the sangha, many monks also genuinely supported the Marxist revolution (Holt 2009, 124).

By 1973, a third attempt at a coalition government between royalist and Marxist forces fell apart. In 1975, the Pathet Lao declared victory, and the country was formally renamed the Lao People's Democratic Republic (LPDR). Initially, the new regime took a heavy-handed approach to religion. Stuart-Fox (1983) writes, "Monks either volunteered or were prevailed upon to attend political re-education seminars, where they were encouraged to adopt "progressive" attitudes and prove themselves by communicating the policies and decisions of the Pathet Lao leadership to the mass of the people." (StuartFox 1983, 444). Upon the formal victory of the Pathet Lao, many monks and ordinary civilians fled the country for Thailand.

Formally, the independence of the Lao sangha was curtailed by the LPDR, with a new regime-sponsored reorganization scheme called the Lao United Buddhists Association. This move eliminated the formal organizational division between Thammayut and Mohinikay monks (Stuart-Fox 1999, 163). Significantly, under the LPDR regime, there was no widespread attempt to crack down on monks as was the case in neighboring Cambodia, and to some extent Vietnam. Rather, it appears as though the LPDR was sensitive to the political ramifications of their policies on religion. While the regime took control over religious education, coercive measures taken against monks were often met with popular protests. After such protests, the regime would amend its 
policies to appease dissident voices (Ibid). Perhaps more than any other state in the region, despite its Marxist ideological commitments, Laos saw the political utility in promoting Buddhism. Monks in Laos served in prominent government positions and were often used as a mouthpiece for government ideology (Ibid, 164). The degree to which monastic participation in these schemes was voluntary or coerced is difficult to determine. What is clear is that the regime did not see any incompatibilities between their policy agenda, on the one hand, and the cultivation of Buddhism, on the other.

\section{Laos 1976-present: Marxist Rule}

During the late 1970's, based in part on economic hardship, the Lao PDR instituted changes intended to scale back the ability of Lao people to make direct donations to the sangha. Festivals were also closely monitored, and limits were placed on the number of novices allowed to enter the monastery. However, after the passage of the 1991 Constitution, Buddhism was the only specific religion named, with the government, encouraging Buddhists to participate in "those activities which are beneficial to the country" (Evans 1998, 65).

By the 1980's, Laos was facing severe economic crisis and engaged in a series of political and economic reforms. At this time, leadership promoted policies designed to reinvigorate the role of Buddhism in society. Public Buddhist festivals were no longer strictly regulated, and the regime took a softer approach toward regulating the religious behavior of monks. Even at the death of long-time communist dictator Kaysone (19551992), there was a Buddhist funeral ceremony complete with chanting Buddhist monks (Stuart-Fox 1999, 176). 
With the decline of the Soviet Union, Cambodia, Vietnam, and Laos all embarked on paths of political and economic liberalization. In this respect, circumscribed space was afforded to Buddhism in Laos. Grant Evans writes, "During the liberalization of the 1980's, Buddhism, although flourishing was still subordinate to the party's long-term aim of building socialism in Laos" (Evans 1998, 67). However, it is evident in recent years that the regime has been increasingly dependent on Buddhism for ideological legitimacy.

Due to the late centralization of politics in Laos, the sangha was never truly organized until after the victory of the Pathet Lao in 1975. Evans (1998) writes, "The increasing role played by the modern bureaucratic state in the affairs of Buddhism in Laos was belated, compared with Thailand" (Ibid, 52). Additionally, contemporary linkages between the state apparatus and the Lao sangha are much weaker as compared with Thailand. Pholsena writes, "Buddhism may have been granted a new political role, but its newly reformulated function is nowhere near the type of strong alliance that has never ceased to exist in neighboring Thailand" (Pholsena 2006, 69). What is most evident in Laos is that socialists in power have attempted to mold their ideology to Buddhism. This newfound endorsement of Buddhism is not without complications, as nearly $1 / 3$ of Lao citizens are not Buddhist. Instead, new regime policies toward religion may accelerate inter-faith distrust.

\section{Vietnam 1945-1975: Persistent Warfare}

As a rag tag group of revolutionaries founded in 1930, the Communist Party of Vietnam (CPV) grew rapidly in a relatively short period of time. Tuong Vu (2014) reports that the party grew from a few thousand members in 1945 to 430,000 in 1949 (Vu 
2014, 24). Specifically, the fusion of Marxist economic principles with Confucian notions of individual morality and social responsibility resonated with many traditional Vietnamese. Internally, the Viet Minh retained cohesion through shared responsibilities and a commitment to not banish dissident voices from the party. In this respect, the Vietnamese communists avoided the frequent party purges that characterized Stalin's Russia and Mao's China. By 1960, the party had nationalized most private property and undertook massive land reforms (Ibid, 25)

Early attempts at governance included massive land redistribution policies and agricultural collectivization. The Viet Minh introduced tax reform and basic literacy initiatives as a means of building regime legitimacy as early as 1945 (Beresford 1988, 23). Following the defeat of the French at Diem Bien Phu in 1954, the Viet Minh sought to extend their military control and popular support across the north. This was an uneven process, as reforms were not always popular, resulting in Ho Chi Minh even publicly apologizing for poor policy implementation (Vasavakul 1995, 267). Yet, it is clear during this period that the CPV had a clear plan for enhancing state capacity in the North.

Despite Vietnam's history of religious syncretism, sectarian and inter-religious conflict became a feature of Vietnamese politics at the same time when the communists in Vietnam were becoming more powerful. While the French were successful in converting large numbers of Vietnamese to Catholicism, many Buddhists, Marxists, and religious minorities viewed Catholics as agents of a foreign power. Chapman (2012) writes, "In 1945, via the August Revolution the communist Vietminh first aimed to win support from Catholic communities but ultimately came to view them as legitimate 
targets of anticolonial violence" (Chapman 2012, 208). During the first Vietnam War, the Vietminh targeted Catholics for their suspected ties to the French (Abuza 2001, 183). As the Vietminh continued to consolidate territory in north Vietnam, a different sort religious conflict was also brewing in the south.

In terms of religion, the communists had to reckon with four major religious groups- Catholics, Buddhists, Hoa Hao, Cao Dai-and a series of smaller organizations. Of the four, Catholics had the largest political influence in South Vietnam, with the American sponsored Diem regime as its most prominent representative during the 1960's. In the north, since 1954, however, there was no evidence to suggest that the communists were targeting individuals specifically for their religious beliefs (Matthews 1992, 66). Despite the absence of mass violence against Catholics, many in the north assumed that their lives would be in jeopardy under communist rule. As such, large-scale Catholic refugee flows from the north to the south transpired during the Second Indochina War. ${ }^{54}$

Buddhists played a significant role in protests during the Vietnam War, and were at times outspoken critics of the communist regime. Crackdowns against Buddhists were not uncommon, especially after the Fall of Saigon. The Hoa Hao, a fundamentalist strain of Buddhism, had a militant presence, and at times engaged in direct confrontation with the regime. The American-supported Diem regime and the communists alike saw the Hoa Hao as an internal military threat and took steps to eliminate prominent members. Finally, Cao Dai, a syncretic religion containing elements of Buddhism, Christianity, and

\footnotetext{
${ }^{54}$ There is some sparse evidence to suggest that Diem strategically relocated Catholic refugees from the north to serve as a firewall against Buddhist rebellion. This account is a matter of continued discussion.
} 
traditional folk religion had been the least resistant of the four religions, though remained a regime target after unification (Beresford, 126)

Following the withdrawal of the French, the United States, alarmed by developments in the north, decided to establish a bulwark against communism in the leadership of Ngo Dinh Diem. Once in power, Diem consolidated his power through nepotism and patronage networks that benefitted the Catholic minority. While Diem's regime created a gulf between Catholicism and other religious groups in south Vietnam, his regime was materially sustained through large aid transfers from the United States. Lacking widespread popular legitimacy, Diem ruled by violence. Buddhist grievances against the regime dated back to the 1950's, stemming from political exclusion and land reform policies that overwhelmingly benefitted Catholics. Ostensibly, the conflict began when Buddhists, in celebration of the Buddha's birthday, flew prayer flags in the streets of Saigon. The Diem regime responded by outlawing all unapproved religious symbols from the public sphere. Protests escalated, resulting in violent crackdowns.

Repeated crackdowns against suspected communists-as well as non-Catholics-led to two major crises. The first, in 1955, is known as the sect-crisis. The Cao Dai, Hao Hoa and Binh Xuyen, the largest crime syndicate in South Vietnam, combined forces to demand concessions from the regime. Forming the United Front of Nationalist Forces, these groups engaged in a military struggle with the regime.

In 1956, Diem and his security apparatus declared their "Denounce the Communists Campaign" which resulted in the arbitrary arrest and imprisonment of individuals viewed as a threat to the state (Ibid, 216). Diem's policy resulted in the 
arbitrary arrest and persecution of large numbers of South Vietnamese. After Diem's assassination, successive military regimes in the south continued to persecute Buddhists for the remainder of the war.

In the Republic of Vietnam (south), the most controversial showdown between Buddhists and the government was the 1963 Monastic Crisis. Here, protests were largely in response to the persecution of the Buddhist majority in South Vietnam at the hands of the Diem Regime. In 1963, in the central city of Hue, a protest was put down, resulting in the deaths of nine people. On June $11^{\text {th }}$ of that same year, Buddhist monk Thich Quang Duc set himself on fire in public. Buddhists continued to petition the government into the late 1960's, after the fall of the Diem government.

Yet, as the war raged on, Buddhist activists concentrated their activities on social welfare provision (Tarling 1999, 217). Additionally, in response to regime violence, Buddhists formed the "Intersect Committee for the Defense of Buddhism", which acted as a group designed to negotiate an end to the conflict with the Diem government (Schuck 1966, 49). In central Vietnam, two influential monks, Thich Tri Quang and Thich Tam Chau were crucial to organizing Buddhists against the Diem regime (Ibid).

Outside of South Vietnam, the United States lost faith in the Diem regime for their handling of the Buddhist Crisis. Shortly after, in 1964, Diem was killed by his own military officers. After the execution of Diem, a series of U.S.- backed regimes were viewed as merely an extension of the repressive Diem regime, leading to the increased defection of South Vietnamese to the Viet Cong (Ibid, 222). 


\section{Vietnam 1975-Present: Unification and Marxist Rule}

After 1975, the CPV had emerged victorious from war against the United States/Republic of South Vietnam coalition. Yet, the war also took a massive toll on human capital. In the 1980's, facing the decline of a reliable partner in the Soviet Union and an aging Vietnamese politburo, the CPV was compelled to institute market-based reforms. However, these same reforms also created rent-seeking behavior and massive party-based corruption (Vu, 237). Since 2006, high inflation and decaying state-owned industries have stunted economic growth. What has remained consistent is the sophisticated surveillance apparatus instituted through extensive party organizations. This has not only shaped the direction of civil society, but also the administration of organized religion since 1975 .

Following the withdrawal of American troops, Saigon collapsed, and Vietnam fell under communist control. Shortly after unification, the CPV took direct repressive action against organized Buddhism. As Robert Topmiller (2000) observes, "In time, security forces raided pagodas, closed down orphanages, disbanded religious organizations and placed prominent Buddhist leaders like Thich Tri Quang under house arrest or imprisonment in remote locations" (Topmiller 2000, 234-235). Next, the CPV moved to create their own Buddhist organization, the Vietnamese Buddhist Church (VBC). Once established, the regime quickly moved away from mass religious repression, and selectively targeted dissident voices.

In terms of religious organization today, the Department of Religion is charged with supervising the behavior of religious adherents across Vietnam. While not 
particularly repressive, it does put limits on how many individuals can enter monasteries or churches for religious life (Matthews 1992, 66). Buddhism itself is regulated through the Vietnam Buddhist sangha. While largely self-regulating, it attempts to bring itself into closer ideological alignment with the communist state. In 1980, Matthews writes, "the sangha adopted the charter slogan "Dhamma, Nation, and Socialism" (Ibid, 68).

For its part, the Catholic Church in Vietnam has consistently lived in fear of destruction, yet there are few major restrictions on individual religious practice. Mass attendance in South Vietnam is high, though the Catholic Church is very careful not to challenge the state authorities. While it is permitted to collect foreign donations, the Vietnamese Catholic Church is proscribed from having a direct relationship with the Papacy in Rome (Matthews 1992, 70). Presently, the Vatican and Vietnam have been in talks to "upgrade" diplomatic relations.

The 1992 constitution allows individuals to "worship or not worship" but the Politburo strictly regulates organizations. All religions must report to the Vietnamese Fatherland Front, as religion is seen as arm of the state (Abuza 2001, 186). Under this arrangement, the government controls ordinations, and church property. Specifically, the regime sets limits for the number of monks who can enter a monastery annually and treats monastery/church property as state property. The regime also does not want churches to undertake development activities. Relations with the Cao Dai and Hao Hoa sects remain poor, as the regime frequently accuses these groups of subversive activities.

In contemporary Vietnam, then, there is a serious disparity between the freedom afforded to individual practitioners and restrictions placed on religious organization. As 
Abuza remarks, the "debate over religious freedom has little to do with faith and everything to do with the right to organize outside party control" (Ibid, 183). Since the 1980's, the VBC has relaxed its controls over the practice of religion in public and has opened formally closed monasteries as cultural sites (Taylor 2004, 44). Therefore, while individual believers are free to attend services and participate in the rituals of their faith, churches and monasteries remain closely monitored.

Synthesizing State Capacity and Religious Organizations in Cambodia

The weakness of the post-1945 Cambodian state is partially attributable to its colonial experience, as discussed earlier in this chapter, but was magnified by a series of highly personalistic and corrupt regimes. In post-independence Cambodia, the political space was dominated by the idiosyncratic behavior of Prince Sihanouk. When Sihanouk abdicated and started his own political party, virtually all national wealth was in the hands of connected Phnom Penh politicians and business figures. While Sihanouk was viewed positively by some Cambodians, the Khmer Rouge fed off economic and moral resentment targeted at Phnom Penh. The rise of the Khmer Rouge, itself a product of broader regional developments, was hastened by the Cambodian state's inability to create a monopoly of violence over the country. A weak and highly factionalized military was no match for a relatively small group of eastern Cambodian revolutionaries. In short, the Khmer Rouge's ability to take the country with unsophisticated weaponry and little foreign support was indicative of Cambodia's weak state capacity.

While the Khmer Rouge destroyed the remnants of a weak state, the country was effectively occupied by a foreign power (Vietnam) during the 1980's. Though some 
advances were made in administrative capacity and military modernization, the Cambodian state is still one of the poorest in Southeast Asia. Presently, it is held together by another personalistic leader, Hun Sen, and his network of supporters. Unlike Vietnam, there have been significant domestic challenges to the Hun Sen regime. During the 1990's and early 2000's, Levitsky and Way (2010) considered it a "competitive authoritarian regime" as the democratic opposition had a reasonable chance of unseating Hun Sen (Levitsky and Way 2010, 330-337). Yet, serious election rigging since 2003, coupled with high levels of voter intimidation and physical repression, have rendered recent electoral challenges virtually meaningless.

In terms of bureaucratic/administrative capacity, values for government effectiveness ranks as the second lowest in the region, surpassed only by Burma. Turning to coercive capacity, Cambodia features a small military (never larger than 300,000 troops) and spends a small percentage of its overall GDP on this institution. In these categories it is trailed only by Laos and Malaysia.

\section{Synthesizing State Capacity and Religious Organizations in Laos}

Laos, itself not a viable state until the French colonial period, was administered with little in the way of direct French supervision. Additionally, topographical features have long made Laos the most isolated state in southeast Asia. Undoubtedly, the success of communist rebel forces in Laos, as in Cambodia, and South Vietnam was in part due to the weakness of the state apparatus. Though possessing a similar colonial history as Cambodia, notably the direct intervention of a member of the Royal family in leftist 
politics, spillover from the Vietnam War, and a brief failed experiment with a right-wing military regime, political outcomes in Laos were quite different.

Civil war in Laos, though it led to the victory of the Pathet Lao, did not lead to the destruction of the country as it did in Cambodia. In this case, the ideological disposition of the Pathet Lao vs. the Khmer Rouge is significant. While the Pathet Lao feared alienating ethnic minorities like the Hmong and the Buddhist establishment, the Khmer Rouge sought to destroy Vietnamese and Cham Muslim minorities, and virtually destroyed the sangha. While the ideological goals of both organizations differed, in some respect, each regime was reacting differently to a shared legacy of low state capacity. The Pathet Lao knew that they lacked the strong coercive and bureaucratic resources required to dominate the state, so they governed by accommodation. Throughout the 1970's and 1980's regime policies were frequently adapted and then revised based upon the reactions of both ethnic minorities and Buddhists alike.

In Cambodia, the Khmer Rouge conquered a weak state, and then sought to implement their revolution rapidly to liquidate all possible domestic challengers, partly in anticipation of aggression from neighboring Vietnam. The gradual liberalization of the religious space, first through the Vietnamese, and then the Socialist party culminated in Buddhist revitalization efforts during the 1990's and 2000's. Most importantly, state weakness in Laos and Cambodia meant that successive regimes were more likely to experiment with both religious co-optation and coercion to achieve their goals. In the end, both contemporary Marxist regimes have realized that they required religious support as an important pillar of legitimacy 
Laos is indicative of a state with low coercive and bureaucratic power. It has the smallest military in the region (less than 130,000 troops) and spends the least amount of its GDP on the armed forces. It is the third weakest bureaucratic/administrative state in the region, trailing only Cambodia and Burma in government effectiveness. Furthermore, security in Laos is frequently jeopardized by the presence of embedded organized crime syndicates. Conflict between the central government in Vientiane and ethnic minorities in the highlands has often revolved around the profitable opium and methamphetamine trade.

\section{Synthesizing State Capacity and Religious Organizations in Vietnam}

Unlike its neighbors in Cambodia and Laos, Vietnam featured a Confucian-style bureaucracy prior to the arrival of the French. During the colonial era, the French devoted more resources to the maintenance of the Vietnamese colony as it was viewed as an important point of access to the Chinese market. Similarly, France invested more time and money in educating Vietnamese citizens, particularly in the South, as opposed to their efforts in Cambodia and Laos. This was not merely a matter of convenience, instead Cambodia and Laos were incorporated into French Indochina almost exclusively to serve as a territorial buffer from expansionist Thailand.

Of course, as the $20^{\text {th }}$ century progressed, noticeable differences in the politics of north and south Vietnam became apparent. Early nationalist resistance to the French transformed into state-building efforts in North Vietnam. Mass village mobilization, and land redistribution began early on in North Vietnam, and as the First Indochina War raged on, the Viet Minh had already created a Leninist-style bureaucracy. Here, the 
communists did not have to build from scratch as they already had inherited the building blocks of a modern state apparatus.

Meanwhile in the south, historically characterized by administrative decentralization and patron-client politics, leaders lacked the tools or incentives to construct a strong bureaucratic state. As discussed earlier, the American-sponsored Diem Regime was fraught by high levels of elite fragmentation and a coercive apparatus completely reliant on foreign largesse. Additionally, the Diem regime did not feel the direct effects of the communist insurgency until late in the Second Indochina War. Dan Slater (2010) observes, "with no active leftist insurgency to confront-or out-organizeeven in rural areas-Diem had neither the incentive nor the capacity to build strong state and party institutions to buttress his rule" (Slater 2010, 257). Only after the 1968 Tet Offensive, did South Vietnam elites begin to coalesce over a shared goal to combat NVA aggression. Sensing immediate danger to life and property, the South Vietnamese stepped up state-building efforts in the south. However, years of governing through nepotism and repression against Buddhists and the minority sects left few sympathetic citizens to mobilize. By the early 1970's, the US commitment to winning the war in Vietnam winded down, and the south lacked time and resources to stall the NVA and Viet Cong advance.

Since 1975, the CPV has ruled the north and the south differently. While land reform was initially successful in the north, it ran into significant problems in the south. Additionally, military threats from neighboring Cambodia and China incentivized the continued construction of the military. In the Vietnamese case, wars against the French, 
Americans, and Cambodians strengthened the coercive arm of the state. Financial support from the Soviet Union also improved Vietnamese military capabilities. With the impeding collapse of the Soviet Union in the 1980's, and its withdrawal from Southeast Asian politics, Vietnam began to introduce a series of market reforms, while forestalling meaningful political liberalization. Despite protests from prominent religious figures and regime defectors, there is no sign that contemporary Vietnam is vulnerable to popular revolution like in Burma. Instead, the Vietnamese state has only become stronger in both bureaucratic and coercive capacity over time $\mathrm{e}^{55}$.

With respect to bureaucratic/administrative capacity, Vietnam ranks third in the region in terms of government effectiveness. While trailing Thailand and Malaysia, Vietnam is still far ahead of neighboring Cambodia and Laos. This capacity developed rapidly after the conclusion of the Vietnamese War and through the introduction of market reforms in the 1980's.

In terms of coercive capacity, as measured by the number of military personnel, Vietnam dwarfed all other Southeast Asian countries in this study with over 1 million troops from 1985-1990. Since then, partially in response to the end of its occupation in Cambodia, troop levels dropped, though they remain on par with Burma's. The difference of course is that Vietnam's military is more technologically sophisticated than Burma's and does not spend as much money relative to GDP.

\footnotetext{
${ }^{55}$ This is not to say that Vietnam's state capacity hasn't also been undermined by endemic corruption and economic mismanagement.
} 
Vietnam's approach to managing organized religion has remained relatively consistent over time. The growth of the coercive and bureaucratic/administrative state apparatuses after unification meant that the VCP could in effect fully co-opt Buddhist and Catholics by creating state churches. At the same time, the regime selectively employed coercive tactics targeted at dissident religious leaders. Unlike Burma and Cambodia, post-unification Vietnam has not had to rely on extensive public crackdowns against religious figures.

\section{Conclusions}

Cambodia, Laos, and Vietnam all share the painful historical legacy of political violence wrought by French colonial occupation and their violent exit from the region. The Second Indochina War, as a direct extension of the first war, forever altered politics in each of the three countries. Yet, variations in approaches to organized religion on the part of authoritarian elites, demonstrates the extent to which historical patterns of state development matter.

The following chapter takes the analysis of the relationship between the state, authoritarian regimes, and organized religion away from Southeast Asia. In the interest of determining whether my theoretical framework can "travel" well in other regions, the cases of Nicaragua, Poland, and the Democratic Republic of Congo will be closely scrutinized. 


\section{DEMOCRATIC REPUBLIC OF THE CONGO, POLAND, NICARAGUA}

This chapter analyzes how historical variation in state capacity has shaped the range of strategies available to authoritarian regimes as they have sought to contain organized religion in the Democratic Republic of the Congo, Poland, and Nicaragua. Apart from a shared legacy of authoritarian governance, these three countries also feature powerful domestic churches which have played an indispensable role in the politics of each state. In each of the cases, the Catholic Church has functioned as a highly centralized religious organization with a long history of popular legitimacy. Unlike statesponsored Buddhist sangha groupings in Southeast Asia, the Catholic Church claims universality and has functioned as a powerful international actor. This important dynamic cannot be understated as it has shaped the tenor of church-state relations in DR Congo, Poland, and Nicaragua over the longue durée.

In the interest of consistency, the analysis in this chapter restricts itself to periods of authoritarian rule in each of the three countries. Upon formal independence in 1960, the DR Congo descended into political chaos and has been ruled by personalistic authoritarian regimes under Mobutu and then the Kabila family. In Nicaragua, the analysis will be restricted to post-WWII rule under the Somoza family (1945-1979) and then the Sandinistas (1979-1990).

Of the three cases, Poland's authoritarian experience requires the most clarification. In this dissertation, Poland is classified as an authoritarian regime, despite having been ruled indirectly by the Soviet Union. There is no denying that the latter featured a totalitarian regime, particularly during the Stalinist era. However, this case 
study, in part, demonstrates how Poland was governed differently than other Soviet satellite states. Crucially, the presence of civil society organizations, and a powerful Church operating beyond the reach of the Soviet-sponsored Polish regime, raises some important theoretical issues. In concert with Linz and Stepan's (1996) regime typology, Poland during the Cold War era, while displaying some features of a totalitarianism namely a unifying ideology and strong party system, lacked the key element of complete societal control exhibited by classic totalitarian regimes. Finally, and less controversial, Poland's democratic period (1990-present) is largely excluded from this chapter, though I will briefly discuss the role of the Catholic Church under the illiberal (though not fully authoritarian) Law and Justice Party.

The chapter is organized as follows, first, I will explore the contentious political relationship between the Catholic Church and authoritarian regimes in the DR Congo from the late colonial period to the present. While the Catholic Church has been the most visible religious organization in the DR Congo, I will also briefly analyze the political role of Protestant churches as well. The next section analyzes the same phenomenon in Poland, with due emphasis placed on the relationship between the Communist Party and the Catholic Church during the Cold War era. The final case study attends to shifting relations between the Church and authoritarian regimes in Nicaragua. Naturally, a sizeable portion of this case study examines the Catholic Church's role just prior to, and during, the Sandinista era. The final section of this chapter will analyze historical variation in state capacity across the three cases to demonstrate how the former has shaped the strategies regimes in each state have pursued vis a vis organized religion. 


\section{Democratic Republic of the Congo}

The tragic modern political history of the DR Congo has its roots in the brutality of the Belgian colonial period. As in other parts of Africa, the Belgians viewed the region as ripe for economic exploitation. Unlike other colonies, however, the Congo was initially administered as the personal fiefdom of a single monarch, King Leopold II (1885-1908). Governing in a remarkably cruel fashion, Leopold's Congo Free State dehumanized the local population, viewing them as little more than cogs the booming rubber and ivory trade. At the outset, an important distinction should be made between atrocities committed under King Leopold's Congo Free State $(1880-1908)^{56}$, and the formal Belgian colonial period (1908-1960). While the structure of the colonial administration differed, economic conditions for the Congolese population remained dire throughout foreign occupation. Specifically, the development of the mining sector led to large-scale worker displacement, disease, and death during the 1920's (Vanthemsche 2012, 30). Shockingly, Belgian colonization resulted in the deaths of roughly 8 million Congolese, with half of the country's population killed off between 1880-1924 (Weisbord 2003, 36).

For its part, the Catholic Church worked closely with the colonial leadership, particularly in the areas of education and social service provision. Implicit in this action, was a collective psychological tendency for Catholic missionaries to either ignore or justify the abuses committed by the colonial administration. Weisbord (2003) writes,

\footnotetext{
${ }^{56}$ For an outstanding account of the Congo Free State, and its impact on Belgian politics see Hochschild
} (1999) 
"Incredible as it seems, many missionaries praised His majesty for relieving the African population of their moral and physical degradation and for preparing them to take their place among the "civilized nations" (Weisbord 2003, 42). Belgian colonialism in the DR Congo was initially sanctioned by the Vatican, and received support from high-ranking officials, including the highly influential American Cardinal James Gibbons (Ibid, 40).

In exchange for their leadership role in administering education and healthcare, the Belgian colonial authorities permitted the Church to proselytize and convert the indigenous population (Longman 1998: 55). While the Catholic Church was the most visible and politically-connected religious organization during the colonial era, Protestant Churches, including a particularly influential Congolese sect known as the Kimbanguist Church ${ }^{57}$ established their own Christian communities in the early $20^{\text {th }}$ century. Protestant Churches, though a minority, were instrumental in drawing international attention to the human rights abuses committed in the Congo.

Upon its formal independence, the DR Congo found itself at the center of both domestic conflict and international Cold War politics. Throughout the 1950's, Congolese nationalist movements put pressure on Belgian authorities, and the international community to grant independence. These Nationalist groups, however, were split both along ethnic and political lines. Political unrest during the 1950's culminated in the Leopoldville Riots of 1959, and the Congo Crisis (1960-1965). While ethnic

\footnotetext{
${ }^{57}$ For more on the political relevance of Protestantism in DR Congo see Garrard (2013) and Ellis and Ter Haar (1998).
} 
considerations were a large contributor to the conflict, as evidenced by secessionist movements in Katanga and South Kasai respectively, there was a crucial international dimension as well, characterized by U.N. intervention and great power competition between the United States and the Soviet Union.

During the political turmoil of the late 1950's, the DR Congo's first Prime Minister Patrice Lumumba turned his back on the United States in favor of Soviet support. In 1961, Lumumba was assassinated at the hands of Katangese secessionists, though the historical record also cites American and Belgian complicity, if not direct assistance, in his demise ${ }^{58}$. Following the Lumumba assassination, DR Congo spiraled into chaos. After a brief period of military rule, power was transferred back to the civilian administration only to be usurped once more by Mobutu Sese Seko in a decisive military coup in 1965. At the heart of the political chaos were issues that still plague DR Congo presently, namely, an ongoing conflict between the central state and regional power brokers.

In the early years of the Mobutu regime, as in the colonial period, the regime saw some utility in coexisting with the Catholic Church. As Longman observes, "Churches helped to provide symbolic legitimacy to the state, while the state facilitated church activities" (Longman 1988, 55). In order to cut state spending, the Mobutu regime relied heavily on the Catholic Church to fulfill social service obligations which would otherwise be under the purview of government. While this policy helped the regime in the shortterm, eventually it put more power in the hands of non-government agents, thus further

\footnotetext{
${ }^{58}$ For more on this topic see De Witte (2001)
} 
weakening the viability of the state bureaucratic/administrative apparatus. It also set the stage for a longer period of conflict between Church officials- who disapproved of Mobutu's kleptocratic rule- and the regime which sought to exercise greater control over church behavior.

In the early 1970's, Mobutu clashed publicly with Church hierarchy, most notably during his scheme to nationalize Church schools. State weakness proved a problem in this case, as the regime discovered that it lacked the bureaucratic resources to administer the educational system (Ibid). In turn, educational responsibilities were handed back to the Catholic Church, based upon a broader understanding that the Church, as an institution was too powerful to co-opt. As Garrard (2013) observes, "The state may have given up on ever being able to dominate and control the Catholics" (Garrard 2013, 137). This is not to say that all church hierarchy was as outspoken with their criticism of the Mobutu regime Indeed, many saw the utility of cooperating with the regime, particularly those from the dictator's own ethnic group.

Attempting to legitimize his rule in an otherwise failing state, Mobutu embarked on a policy of “authenticity' during the 1970's. In symbolic terms, Mobutu changed the name of the Democratic Republic of the Congo's to Zaire and encouraged the removal of "corrupt" western influences from the country. His policies had a deeply personal impact on Christian communities in the Congo as Mobutu mandated name changes for Christians, and the end of public Christian holidays (Longman 1998, 58). Mobutu also sought to control smaller Christian denominations, as evidenced by the regime's decision to unite all Protestant denominations under a single umbrella organization, the Church of 
Christ of Congo (ECC). Garrard (2013) observes, "This amalgam of groups under one grouping and the way it was enacted with the help of state complicity meant that the Protestant Church lost its real voice to criticize the state" (Garrard 2013, 134). This was certainly not the case with the Catholic Church, as prominent members still spoke out against Mobutu's regime.

Economically, Mobutu nationalized major industries and banks, leading to near economic collapse. While the bureaucratic state apparatus was fledgling, particularly during a period of flagrant mismanagement during the 1980's, the coercive arm of the state was still in a position to combat domestic opposition. This was in no small part due to the financial support from the United States. Schatzberg (1997) notes that while Mobutu saw utility in keeping the armed forces splintered, so no group could effectively challenge his rule, the latter still engaged in "extortion, arbitrary arrest, detention without trial, and extrajudicial executions" (Schatzberg 1997, 75). While soldiers and paramilitary groups loyal to Mobutu did carry out selective attacks against dissident Church members, there is no evidence to suggest that the regime ever attempted a broader anti-Catholic crackdown.

By the early 1990's a variety of internal and external political events conspired against Mobutu. The economic consequences of personalized rule meant that decades of state resources captured by the dictator and his loyalists put the rest of the country on the brink of financial disaster, particularly when the commodities markets collapsed. By the 1990's, Mobutu's regime was kept afloat through foreign aid and personal loyalty. However, this was not enough to keep frustrated Congolese citizens off the streets. Anti- 
Mobutu protests in the early 1990's was actively sponsored by the Catholic Church. The regime responded to public protests with a series of violent crackdowns (Schatzberg, 76). Meanwhile, regional secessionist movements in accelerated in the north and east, where the regime never exercised a Weberian monopoly of force. Ultimately, spillover from the Rwandan genocide culminated in war pitting Mobutu's supporters against Laurent Kabila's AFDL forces in the Eastern Congo. Ultimately, Tutsis fleeing Rwanda set up base camps in Congo, with the Rwandan government assisting Kabila in his efforts to unseat Mobutu.

After declaring victory, Kabila, much like his predecessor, embarked on a path of personal enrichment. From the 1990's to early 2000's violent conflict broke out in DR Congo, featuring combatants from Uganda, Rwanda, Angolan and Zimbabwe. Laurent Kabila lost support from his Ugandan and Rwandan supporters in the late 1990's, leading to numerous attempts to replace him. (Dizolele 2010, 146). In 2001, Laurent Kabila was ultimately assassinated and succeeded by his son Joseph, who led the country until early 2019. During this time period, the Catholic Church was active in peace negotiations. In 2003, the Church played a significant role in bringing enemy combatants together for the Inter-Congolese Dialogue at Sun City, South Africa. Here, the Church sent several delegates to the conference, which resulted in the formation of the transitional government (Whetho and Uzodike 2008, 63).

Under Joseph Kabila, state weakness accelerated as the national military was unwilling and unable to curb the influence of foreign armies. "The absence of an effective state has encouraged neighbors Angola, Rwanda, and Uganda to encroach on 
DRC territory under various pretexts, backing militias and looting natural resources." (Dizolele, 153). Under Joseph Kabila, the country witnessed repeated power grabs through unfair elections, constitutional changes, and multiple election postponements. The Catholic Church, after brokering a series of agreements between Kabila and the opposition, ultimately played a powerful role in the protests leading up to the 2018 elections. Led by the CLC (the lay coordination committee), Catholics led three protests in 2017 and 2018, resulting in corresponding government crackdowns (Chick, 2019).

Unlike Protestant denominations in DR Congo, who fell prey to Mobutu's religious reorganization schemes, the Catholic Church endured as a politically powerful actor willing to challenge Mobutu and his successors. As the preceding mini-case study suggests, this was not because authoritarian regimes in the DR Congo respected Church authority, but rather that they lacked the bureaucratic/administrative resources required to pursue policies of cooptation. Ironically, most of these resources had been ceded to the church. In this respect, policies of cooptation appear to be influenced more by ethnicity, than church hierarchy. Violent crackdowns against Catholics, particularly in the Joseph Kabila era have not weakened the role of the Church but have emboldened Catholicbased opposition.

\section{Poland}

The relationship between the Catholic Church and the Polish state was wellcemented before the arrival of communist rule post-WWII. As Monticone (1986) observes, "The Catholic Church was so closely linked with the formation of the Polish state and its historical process that it is difficult to separate the Polish nation from the 
Church" (Monticone 1986, 1). Even when partitioned by Russia, Prussia and Austria in the $18^{\text {th }}$ century, the Catholic Church became the pre-eminent institution in the country (Ibid). Furthermore, the Catholic Church in Poland has always received broad-based support from society. In terms of legitimacy, no government has been able to displace the symbiotic connection between the Catholic Church and Polish citizens

Following the devastation wrought by Nazi occupation, which alone claimed the lives of nearly $1 / 3$ of Warsaw's population, Poland emerged as a state firmly within the Soviet sphere of influence. Initially, the Polish communist regime did not target the Catholic Church with the same vigor as it did in other Eastern European countries. Political historians attribute this Stalin's insistence that he consolidate revolutionary support first in Poland, a country which he already perceived as a poor fit for communism. ${ }^{59}$ Instead, the regime sought to first consolidate political power in Poland. Murak (2012) writes, "Until the destruction of its political opposition and the antiCommunist military units, which was accomplished by 1950 , the regime covered its atheistic face with a religious mask, as its hunger for power was larger than its ideological anticlericalism" (Murak 2012, 250).

Indeed, during the Stalinist era, many communists in Poland had split loyalties between the Church and their official party duties. Here, communist officials openly attended Catholic ceremonies and rebuilt war-damaged churches (Eberts 1998). Perhaps unsurprisingly, many Polish security officers still practiced their religion, in defiance of

\footnotetext{
${ }^{59}$ Stalin is reported to have said that turning Poland into a communist state was like 'fitting a cow with a saddle'.
} 
regime ideology. Murat adds, "some security functionaries were still unable to "unchain their minds" from Catholicism, participating clandestinely but more or less regularly in religious ceremonies" (Murat, 256). Around that time, the communist regime also supported a Catholic revolutionary group (PAX) which had little public credibility (Ibid, 251).

Strategic tolerance for religion in Poland was short-lived, and by the early 1950's the regime sought to make life for Catholics increasingly difficult. In 1950, the party moved to nationalize Church property, and take control of Caritas, the most visible Catholic social service organization in Poland. In 1953, the regime began to replace priests it viewed as undesirable with 'patriotic priests' (Monticone 1986, 17-19). At a low point in Church/regime relations, highly popular Stefan Cardinal Wyszynski was arrested by the regime. Yet despite the efforts of the Communist regime to interfere in the business of the Catholic hierarchy, there were never any large-scale anti-Catholic purges during this time period. The regime was keenly aware that the Church was still the most popular institution in the country, and the events of the 1950's only strengthened its power and popularity. As Kemp-Welch observes, "Despite the ravages of Stalinism in Poland, important differences from the imported 'Soviet Model' still prevailed. Above all, the Catholic Church survived persecution, perhaps thrived on it, and remained a powerful force independent of the state" (Kemp-Welch 2008, 44)

The Catholic Church was also strategic in its dealings with the regime and Polish society. In the first case, Catholic leadership never went so far as to call for the outright destruction of the regime. While Catholics outside of Poland were more dogmatic in their 
insistence that Catholicism faced sure destruction in Poland, high-ranking Church officials in the country saw some utility in cooperation. Secondly, the Church positioned itself on the side of the masses at critical junctures in Polish history. During the university protests of 1968, and the labor strikes of the 1970's, the Church inspired demonstrators (Ibid, 204-205). The latter bond formed between the Church and Labor unions had foreshadowed the success of the Solidarity movement of the 1980's. In turn, the communist regime inadvertently empowered the Church, by relying on it as an important intermediary and negotiating partner whenever the regime came into conflict with Polish workers. As Eberts (1998) remarks, "As the communist authorities became increasingly dependent on the Church to help stabilize the explosive domestic situations, the Church gradually gained more political influence" (Eberts 1998).

During the late 1970's and early 1980's, the Catholic Church not only played an important role in the Solidarity movement, but also provided space for democratic activism (Byrnes 2006, 104). Resistance to the Communist regime was accelerated by domestic and international factors. Economic crisis in Poland, not only fueled mass protests, but drew the support of western sympathizers. Externally, the Vatican played a powerful role in discrediting the legitimacy of the communist regime under the guidance of Pope John Paul II. The Polish-born Pontiff, in his 1979 visit to Poland, explicitly resisted communist ideology and governance. Byrnes (2006) writes, "He rejected the very idea of an eastern Europe and spoke in unprecedented terms of a single continental identity, from the Atlantic to the Urals, that had been torn apart by Yalta, Soviet imperialism, and the so-called realities of the cold war" (Ibid, 105). 
After the collapse of the Soviet Union, and Poland's ensuing transition to democracy, debate on the role for the Catholic Church in the public sphere took center stage. Moral issues like abortion and contraception played a prominent role in discussions surrounding the drafting of a new constitution. However, for the Church the most important issue was a guarantee of freedom from government regulation. "The Polish Church focused on a number of fundamental constitutional issues. The bishops wanted their new national constitution to recognize Roman Catholicism as an organic element of national identity (Ibid, 107). Tangibly, this included a firm guarantee that Catholic schools would no longer fall prey to state control. Presently, the debate over moral issues and the Catholic Church's role in governance continues to play an important role in Polish politics. To date, Poland features some of the most restrictive abortion laws in the European Union, which is in part due to intense lobbying by the domestic Catholic Church.

The rise of right-wing populism in Poland during the 2000's reinvigorated old social and economic cleavages in Polish society. Capitalizing on a growing Euroscepticism in Poland, the PIS (Law and Justice Party) directly appealed to disenchanted members of the working class. As a socially-conservative party, the PIS had important support from prominent members of the Catholic Church. According to Fomina and Kucharczyk (2016), Church support played a "major, if indirect role in PIS victory" during the 2010 and 2015 parliamentary campaigns. (Fomina and Kucharcyz 2016, 61). Whether the PIS era (2015-present) culminate with Poland's transition from illiberalism to outright authoritarianism is beyond the scope of this project. However, the 
close relationship between the PIS and some conservative members of the Church hierarchy in Poland is certainly worth noting.

\section{Nicaragua}

The relationship between the Catholic Church and successive authoritarian regimes in Nicaragua is arguably the most complex of the three-mini case-studies. While low-level conflict between government and the Church was commonplace, particularly after the Sandinista victory in 1979, ongoing divisions within the Church have shaped the political landscape in ways that they did not in Poland or the DR Congo. In this respect, a split in Catholic allegiance between liberal, (at times radical), and conservative factions in the Church is directly relevant to this analysis.

While much of the second half of the $20^{\text {th }}$ century was defined by Cold War proxy war in Nicaragua, the first half established a pattern of U.S. intervention and its corresponding support for right-wing dictatorships. During the 1930's, most Nicaraguans lacked access to education and healthcare, while a small minority prospered from cashcrop exports. Dynastic and nepotistic political rule by the Somoza family exacerbated inequalities inherited from the Spanish colonial period. For much of its history, the institutional Catholic Church and Nicaraguan political society were intensely hierarchical and alienated to the masses. Until the late 1960's, the Church itself was tied to the Somoza regime (Foroohar 1989, 67). Here, there was a meaningful political disconnect between the elites and the impoverished masses. Of this period, Dodson writes, "Political parties never developed a mass base, only making brief appeals to the masses immediately before elections, which were invariably fraudulent, and therefore cynicism 
pervaded the society. Dominated by the coercive power of the National Guard, and lacking political institutions responsive to themselves, the poor were mired in political apathy" (Dodson 1986, 38). This sense of hopelessness among poor Nicaraguans would provide easy fodder for Sandinista recruitment during the 1970's.

Yet, support within the institutional church for the Anastastio Somoza Debayle regime splintered during the 1960 's, largely in response to developments within the Latin American Church itself. Early reforms were visible through the Vatican II conference in 1965, which among other liturgical changes, encouraged the Church to develop a closer relationship with the people. In this respect, Vatican II served as a reminder to Catholics that the Church was meant to represent more than the dictates of the clerical hierarchy. The Bishops Conference in Medellin (1968), and the rise of Liberation Theology both emphasized the centrality of the Church's mission to serve society's most vulnerable. Out of this came a renewed notion that the church should have a "preferential option for the poor" (Erikson Nepstad 1996, 111). In the Nicaraguan context, many priests and nuns, particularly those serving in religious orders, took this message to heart.

After 1968, liberal Catholics began the construction of Christian Base Communities (CEB), which would turn out to have a profound impact on Nicaraguan politics during the tumultuous 1970's. The purpose of these base communities, ostensibly, was to minister to rural areas which traditionally faced a shortage of priests. However, these entities also served an important political purpose. Dodson observes, "In political terms, peasants and the urban poor were traditionally prevented from organizing, or their organizations were controlled by the regime. Although religious in their aims, 
CEBs provided a politically relevant alternative by serving as vehicles through which poor people could organize and meet to discuss common problems" (Dodson, 39).

During the 1970's, coinciding with the rise of CEB's armed leftist resistance emerged as a challenge to Somoza's rule. The Sandinistas, though Marxist in orientation, did not exclude religious individuals from their movement. Dodson observes, "In the two or three years preceding the Insurrection, the FSLN mobilized these grass-roots Christians into the uprising against Somoza, but it did not create their organizations any more than it created their demand for participation" (Ibid, 40). Economic crisis and a devastating earthquake in 1972, in which it was uncovered that Somoza mismanaged disaster relief money intensified domestic opposition. By the early 1970's, Sandinistas were participating in limited armed conflict with the government. At the same time, highranking members of the Catholic hierarchy in Nicaragua began to distance themselves from Somoza. In one such case, Nicaraguan Bishop Obando y Bravo publicly sold Somoza's gift of a Mercedes Benz and gave the proceeds to the poor (Williams 1989, 27).

While the Catholic Church hierarchy tended to view both Somoza regime and the FSLN as undesirable, many priests in rural communities became enamored with the Sandinistas, and actively assisted them. This led to the Nicaraguan Church removing and relocating priests who they viewed had been "radicalized". Instead, the hierarchy sought to build alliances with the moderate opposition, a group which became further marginalized after active conflict broke out between the Somoza government and the Sandinistas. While the Church did not fundamentally change its political position during 
the 1970's, it became clear that it would no longer offer blind allegiance to Somoza either. (Ibid, 41).

With Sandinista victory in 1979, members of the Church hierarchy varied in their reactions to the sudden political change. While most quietly disapproved of the regime, others, such as Jesuit priest Fernando Cardenel SJ, proudly served in government. Upon taking power, the Sandinistas took a less severe stance toward religion compared with other Marxist inspired movements. Williams writes, "The importation of Catholics into the armed struggle must have contributed to the FSLN's rethinking of its originally dogmatic Marxist view of religion" (Ibid, 81). In 1980, the Sandinista government published a document entitled the "Official Communique Concerning Religion", which not only praised the contribution of Christians in the revolution, but also guaranteed freedom of religious practice in Nicaragua (Dodson, 44).

This is not to say that the FSLN always found common ground with the Catholic Church in Nicaragua. In the early 1980's, conflict between the Church hierarchy and the government culminated in the expulsion of ten priests from Nicaragua for "counterrevolutionary activities" (Ibid, 85). The Church was also outspoken when it came to criticize the Sandinistas for human rights abuses during the Contra War. In one such instance, Nicaraguan Bishops spoke up following the forcible relocation of Miskito Indians (Bradstock 1987, 52). Curiously, while the Bishops were quick to criticize human rights abuses committed by the Sandinistas, they remained quiet on Contra activities in Nicaragua. (Berryman 1994, 50). While there was no direct violent confrontation 
between the Catholic Church and the FSLN during the 1980's, the period can be characterized as one of persistent tension.

The brutal war between the Sandinistas and the U.S. trained Contras led to military stalemate by the end of the 1980's. In 1988, a peace agreement was signed effectively signaling the end of the Sandinista regime. A series of center-right governments during the 1990's and early 2000's, were mired by party divisions and corruption, which led in part to the return of Daniel Ortega. His relationship with the Catholic Church mirrors the alternating patterns of cooptation and coercion typically seen in low bureaucratic/administrative and low coercive capacity states. Despite his earlier role as the leader of the Sandinista movement, Ortega won office in 2007 as a social and fiscal conservative. (Lacayo and Lansberg-Rodriguez 2018). As part of his political resurrection, Ortega claimed to have discovered Catholicism later in life, and actively sought the support of his former enemy, Cardinal Obando y Bravo (Ibid). Yet, Ortega's short-lived honeymoon with the Church has soured over the past two years, giving way to open hostilities. Since the start of anti-government protests in 2018, the Church has taken an active role in organizing regime opposition. While in the early stages of the mass protests, Ortega reached out to the Catholic Church for conflict mediation, he has recently identified the Church as an enemy, with his followers recently implicated in high-profile attacks on clergy (Malkin and Robles, 2018).

\section{Synthesizing State Capacity and Organized Religion in DR Congo}

Of the three cases analyzed in this chapter, the DR Congo stands out as the county with the lowest historical endowment of coercive and bureaucratic administrative 
capacity. This is in no small part due to the legacy of exploitative colonial rule. When the Belgians left the Congo, they had failed to create the strong bureaucratic apparatus that a regime could use to effectively govern the state. Since independence, lingering questions over the exact nature of the Congolese state remain unresolved. At base, the degree to which the country should be administered as a unitary or federal state has been at the root of violent conflict over the course of several decades. In terms of coercive capacity, authoritarian regimes based in Kinshasa, first under Mobutu and then the Kabilas, have relied on the politics of ethnic patronage to sustain their rule. Consequently, large swaths of the DR Congo that do not participate in this ethnic network are left ungoverned, or subject to the whims of foreign-sponsored rebel leaders. To date, territories in the Northeast, (Near the Ugandan border), and the Southeast (near Tanzania) remain outside of the control of the central government. The DR Congo's military though numerically large, is underfunded and suffers from poor troop morale, with many soldiers resorting to illegal activities, such as smuggling and illegal property seizure. The central government has also resorted to the use of smaller paramilitary groups to enforce their policies.

While persistent warfare and disease has further strained the state's coercive apparatus, corruption and gross economic mismanagement have weakened infrastructural power. As discussed earlier, the Mobutu and Kabila regimes traditionally relied on the Catholic Church and NGO's to prop up a failing education sector. Occasional crackdowns against the Church have been short-lived, as the government understands the indispensable role the Church plays in social service provision. Finally, poor physical infrastructure exacerbated by the mismanagement of aid money and hostile neighbors has put the DR Congo in an economically precarious position. Apart from the recognition 
afforded to it by the international community, there is little material evidence to suggest that the DR Congo has anything more than the superficial appearance of a modern state.

As many citizens of the DR Congo have suffered unspeakable horrors since the colonial period, the Catholic Church, and to some extent some of the Evangelical Protestant denominations have functioned as an alternative source of legitimacy in an otherwise failing state. Apart from the symbolic power these churches hold in the DR Congo, they have also filled bureaucratic/administrative functions in many crucial areas. As such, dictators in the country have recognized that the Church has traditionally been much closer to the people than the regime. While Mobutu attempted to exercise coercive power over the Church during the "authenticity period", his policies were later reversed. Under the Kabilas, while anti-government Catholics have been targeted by the regime, there has been no large-scale effort to weaken the power of the institutional Catholic Church. In this respect, the DR Congo stands apart as an extreme example of a weak bureaucratic/administrative and coercive state, where regimes desperately experiment with coercion and cooptation in the hopes of limiting the influence of religious actors. Even these efforts were circumscribed, with greater regime attention paid to co-opting numerically smaller Protestant churches.

Synthesizing State Capacity and Religious Organizations in Poland

Polish history has been marked by persistent foreign interference. As such domestic politics have often reflected the will of occupying powers rather than that of Polish self-determination. In the immediate post-WWII period, much of Poland's infrastructure and human capital was destroyed from the war. Falling from Nazi 
occupation into the Soviet sphere of influence, the Polish Catholic Church was the only institution that provided the population with a sense of cultural continuity. While Poland was not a particularly strong state before the war, they inherited a strong state apparatus from the Soviet Union. In coercive terms, the Soviets backed the creation of an advanced Polish security apparatus (Bezpieka). Soviet economic planning resulted in the reconstruction of the Polish industrial sector, with new advances in physical infrastructure present through the Stalinist era. Despite these innovations, this never changed the fact that the Soviet Union was viewed by most Poles as an occupying power ruling through a puppet regime. As such, it already lacked popular legitimacy, which was only exacerbated by their desire to export an ideology which was ill-suited for a deeply Catholic country.

Almost immediately, both Stalin and his supporters within Poland recognized that the power of the Catholic Church in Poland dwarfed the influence of the Orthodox Churches in other countries behind the Iron Curtain. As such, the approach taken toward Poland differed significantly from the rest of Eastern Europe, where many churches faced the real prospect of destruction. While uncooperative clergy were occasionally targeted by the regime's security apparatus, the Catholic hierarchy continued to function as an important intermediary between the Communist regime and the people. Though the regime certainly had the coercive capacity to crack down violently against Catholics, the unique power of the Church in Poland suggested that such a move would be ill-advised. Over time, the Church, which had weathered early repression in the 1950's, emerged stronger and was emboldened by both domestic and international actors. By the 1980's, with the vocal support of Pope John Paul II, the Church was an indispensable partner in 
mediating between the regime and Polish workers. Members of the church also worked alongside secular activists in in the Solidarity Movement which contributed to the end of Communist rule in Poland.

The political role of the Catholic Church in Poland after the end of the Cold War, though not the focus of this chapter, deserves some attention. The Church hierarchy was influential in the drafting of the Polish constitution, the EU question, and still retain a great deal of popular legitimacy. While the emphasis in this research has been on the topdown management of religion through the lens of state capacity, the Polish case demonstrates the importance of religious organizations as powerful agents. In some respects, the Polish case fulfills theoretical expectations, as a powerful Soviet-sponsored state made some efforts to coopt Catholics through the creation of an alternative Church organizations. However, the larger takeaway is that these efforts were haphazard and remarkably unsuccessful, as the Church retained its institutional autonomy throughout the Soviet era.

\section{Synthesizing State Capacity and Religious Organizations in Nicaragua}

Nicaragua's Catholic Church, like the DR Congo, reflects a historical legacy of colonial rule. Since the Spanish colonial period, the Church had a mixed impact on the Nicaraguan population. While clergy provided health care and education to Nicaraguans, the hierarchy often provided a cloak of legitimacy to autocratic leaders. In the early $20^{\text {th }}$ century, the Catholic hierarchy had provided support to the corrupt Somoza family, in the name of remaining above the political fray. However, due to internal reforms in the Catholic Church, as well as the rise of Liberation Theology, the Church increasingly 
found itself divided politically. In Nicaragua, opposition to the Somoza regime took on a Marxist character and was propelled by the creation of rural Christian Base Communities. While many Bishops were hesitant to take a public stance against right wing autocrats, unlike Archbishop Romero in El Salvador, local priests and nuns in Nicaragua did provide support to the leftists.

In exchange for their support, the FSLN took a comparatively laissez-faire approach to Catholicism in Nicaragua. Unlike Poland, which featured a strong state apparatus, the FSLN inherited a weak state exacerbated by decades of Somoza family corruption. Finally, during its decade in power, the FSLN was engaged in a long war with the Contras. This may have influenced its decision not to waste its coercive resources on the Church, though this is purely speculative. While the Sandinistas applied coercive strategies against select members of the Catholic hierarchy, there were no widescale crackdowns against Catholics; many of whom formed the base of Sandinista support. Similarly, in this case cooptation is difficult to assess as many Catholics, particularly from the impoverished classes willingly worked alongside the Sandinistas.

More recently, Daniel Ortega's shift from courting the Church to actively persecuting it represents a new era in Nicaraguan politics. During the past two years, Ortega has charged the Catholic Church with conspiring against the regime. The Church, in turn, has publicly supported anti-regime protests. Ortega's willingness to crackdown against protesting Catholics is clearly indicative of a regime in a state with weak bureaucratic/administrative capacity that alternates between cooptation and coercion as its primary strategy for dealing with religious opposition. However, as the conflict 
between Ortega and the Church is recent, more analysis will be required to determine whether this becomes a pattern of governance.

Coercive and Bureaucratic State Capacity in DR Congo, Poland and Nicaragua

The date presented in Tables 7-9 provides insight into bureaucratic/administrative and coercive capacities in the DR Congo, Poland, and Nicaragua. The values listed here correspond to the data gathered from the World Bank's index of military capabilities and Kaufmann and Kray's "Government Effectiveness Index". As with the other data in this dissertation, these tables provide a snapshot of estimates for bureaucratic/administrative and coercive capacities across cases.

Table 7: Government Effectiveness

Country (2017)

Military Expenditures

\begin{tabular}{|l|l|}
\hline DR Congo & -1.63 \\
\hline Poland & .63 \\
\hline Nicaragua & \\
\hline & -.64 \\
\hline
\end{tabular}


Table 8: Military Expenditures as \% of GDP

Country (2017)

Military Expenditures

\begin{tabular}{|l|l|}
\hline DR Congo & .70 \\
\hline Nicaragua & .61 \\
\hline Poland & \\
\hline & 1.96 \\
\hline
\end{tabular}

Table 9: Military Personnel

Country (2016)

Total Number of Military Personnel

\begin{tabular}{|l|l|}
\hline DR Congo & 134,250 \\
\hline Nicaragua & \\
\hline & \\
\hline Poland & \\
& 12,000 \\
\hline & \\
\hline
\end{tabular}


As expected, the Democratic Republic of the Congo and Nicaragua rank far below Poland in terms of bureaucratic/administrative capacity as indicated by government effectiveness data. The DR Congo's value of -1.63 makes it the lowest bureaucratic/administrative state among the cases selected in this dissertation. Meanwhile, Nicaragua's value of -.64 puts it roughly on par with Cambodia in terms of government effectiveness. Finally, Poland's government effectiveness score of 1.96 dwarfs all Southeast Asian cases. In terms of military personnel and expenditures, Poland outranks the DR Congo and Nicaragua. Nicaragua stands out among all cases as having the lowest number of military personnel.

\section{Conclusions}

The findings in this chapter demonstrate the extent to which theoretical expectations for research in the Southeast Asian context can travel to other regions of the world. Specifically, the tug of war between regime elites and religious organizations appears to be an enduring feature of politics under authoritarianism. This chapter also points to some unexpected findings which emphasize the importance of religious organizations as powerful actors. The Catholic Church, particularly in states with low bureaucratic/administrative capacity possesses far more than symbolic power. Instead, as seen in Congo and Nicaragua, the Church builds strong links on the community level through the provision of education and social services. This echoes the role that the sangha has traditionally held in Burma, Laos, and Cambodia.

The final chapter of this dissertation synthesizes findings, comparing outcomes for cases grouped according to my independent variable, state capacity endowment. It 
then explores alternative avenues for future research, while concluding with the overall contribution of this project to the interdisciplinary literature. 


\section{CONCLUSION}

The preceding analysis has examined the historically contentious relationship between authoritarian regimes and religious organizations in Southeast Asia and beyond. Specifically, extreme variation across cases demonstrates the important role state capacity plays in shaping regime strategies across time and place. As strong states are not built overnight, the historical legacy of state development has a profound influence on the nature of modern authoritarian rule, particularly in the developing world.

Through typological theorizing and qualitative comparative methods, this research reveals how regime behavior is contingent upon broader structural considerations. As hypothesized, stronger bureaucratic/administrative states provide authoritarian regimes with the tools required to co-opt religious organizations, while regimes in weaker bureaucratic/administrative regimes have more eagerly employed violence to contain the political influence of symbolically important religious organizations. State capacity among the six Southeast Asian cases has demonstrated much variation since their respective post-independence periods. This is particularly true with respect to bureaucratic/administrative capacity, as modern authoritarian regimes in Malaysia, Thailand, and Vietnam built upon bureaucratic apparatuses that pre-date independence. Conversely, in Burma, Laos, and Cambodia, post-independence elites have either been incapable or unwilling to do the work required to construct strong bureaucratic states. 
Coercive capacity, as indicated by a regime's military capabilities, varies in proportion to the latter's involvement in civil or interstate conflict. Thus, temporary spikes in the number of military personnel and the percentage of GDP spent on the military has a mixed impact on a state's coercive capacity. For example, decades of civil war in Burma have led to the creation of a larger, (though not necessarily more sophisticated or effective) military. Though large by regional standards, the Burmese army (Tatmadaw) has not established a monopoly of violence over Burmese territory. Conversely, wars in Vietnam from the 1950's-1970's, only strengthened North Vietnam's coercive apparatus culminating in the eventual capture of Saigon. After reunification, the Communist Party of Vietnam (CPV), built upon a strong coercive apparatus forged through decades of conflict. As with bureaucratic/administrative capacity, coercive capacity rarely changes dramatically in the short-term, but can be built over a period of several decades- and it was sometimes accelerated- through foreign military assistance.

As authoritarian regime strategy toward religious organizations is structured by state capacity, this dissertation explains why certain regimes often engage in policies, which on their face, seem counterproductive or even irrational. While authoritarian leaders in weak bureaucratic/administrative states are aware of the unintended consequences of violence against religious organizations, they also recognize that the unchecked growth of these groups could pose a greater threat to the regime in the longterm. Conversely, regimes in strong bureaucratic/administrative states are aware that efforts at cooptation are not always successful, as some members of religious organizations may either resist or renege on regime patronage. Authoritarian regimes in Thailand, Malaysia, and Vietnam, though successfully co-opting religious groups, have 
also employed violence against uncooperative members of these groups. Thus, coercive force in these states is often selectively applied, targeting dissidents with violence or imprisonment as a secondary strategy. Regimes with a high degree of coercive power and a low level of bureaucratic/administrative power are prone to rely on violence as a means of containing religious organizations. Policies in South Vietnam (1945-1975) and Hun Sen's Cambodia (1985-present) are indicative of this strategy. Finally, regimes in weak bureaucratic/administrative and coercive states attempt a mix of strategies designed to contain the influence of these groups. Alternating policies of patronage and violent crackdowns in Burma and Laos are emblematic of this tendency.

Table 10 places states according to their respective values on coercive power and bureaucratic/administrative power. The data gathered for coercive power is from the most recent World Bank’s Military Capabilities Index (2016), while values for bureaucratic/administrative power are taken from Kaufmann and Kray's Government Effectiveness Index (Kauffman and Kray, 2017). These data provide a snapshot of government effectiveness and serve as a proxy for bureaucratic/administrative capacity. As data on both measures do not exist for South Vietnam, it is placed according to estimates based upon my case study research. 
Table 10: State Power in Southeast Asia and Beyond

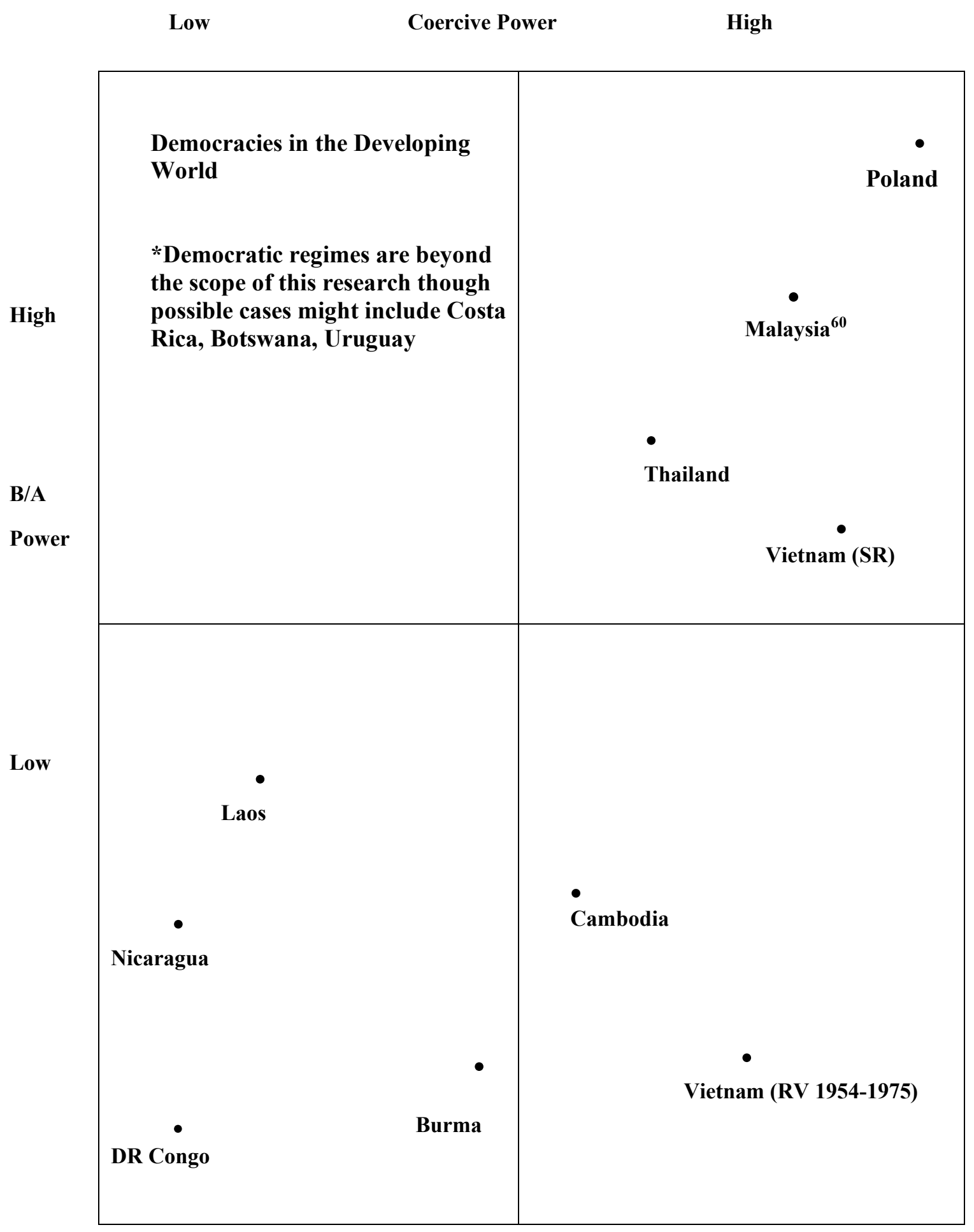

${ }^{60}$ While Malaysia does not have the largest military in Southeast Asia in terms of personnel, it is the most sophisticated. The Malaysian government also outspends its neighbors on advanced military technology. 
Table 11 provides a summary of findings for the case studies, examining the interactions between two varieties of state capacity and regime strategy across the six Southeast Asian Cases and three countries from outside the region. As the table indicates, the strongest states have engaged in cooptation as their primary strategy, while the weakest have engaged in coercion. Cambodia and South Vietnam (1954-1975), stand out as examples of states that relied extensively on their coercive apparatus to confront religious resistance.

Table 11: Summary of Results

\section{Country Major Religion(s) Bureaucratic/Admin Power Coercive Power Regime Strategy}

\begin{tabular}{|l|l|l|l|l|}
\hline Burma & Theravada Buddhism & Low & Low & $\begin{array}{l}\text { Co-opt and } \\
\text { Coerce }\end{array}$ \\
\hline Thailand & $\begin{array}{l}\text { Theravada } \\
\text { Buddhism }\end{array}$ & High & High & Co-opt \\
\hline Malaysia & Sunni Islam & High & High & Co-opt \\
\hline Laos & Theravada Buddhism & Low & & Co-opt and \\
Coerce
\end{tabular}




\begin{tabular}{|c|c|c|c|c|}
\hline $\begin{array}{l}\text { Vietnam } \\
(\mathrm{RV} 1954- \\
1975)\end{array}$ & $\begin{array}{l}\text { Mahayana Buddhism } \\
\text { and Roman } \\
\text { Catholicism }\end{array}$ & Low & High & Coerce \\
\hline DR Congo & $\begin{array}{l}\text { Roman Catholicism } \\
\text { and Protestantism }\end{array}$ & Low & Low & $\begin{array}{l}\text { Co-opt and } \\
\text { Coerce }\end{array}$ \\
\hline Poland & Roman Catholicism & High & High & Co-opt \\
\hline Nicaragua & Roman Catholicism & Low & Low & $\begin{array}{l}\text { Co-opt and } \\
\text { Coerce }\end{array}$ \\
\hline
\end{tabular}

Synthesis of Findings

The preceding analysis demonstrates how state capacity has shaped the complex relationship between authoritarian regimes and religious organizations in Southeast Asia and beyond. While acknowledging that each case features unique historical contingencies, controlled comparison highlights important similarities and differences in authoritarian governance across time and space. What follows is a comparison of findings from cases organized according to my independent variable, state capacity endowment.

In this dissertation, authoritarian regimes were selected for study according to corresponding values on bureaucratic/administrative and coercive capacity. In concert with my theoretical expectations, regimes with access to strong bureaucratic/administrative and coercive state apparatuses have demonstrated a clear tendency to co-opt religious organizations. In post WWII Thailand and Malaysia, 
successive authoritarian regime elites have cultivated close ties with important religious groups. While these policies are in line with a centuries-old Thai and Malay tradition of patronizing religion, the strategic commitment from regime elites in the strong states of Poland (during the Cold War) and Vietnam to pursue any sort of official relationship with religious organizations are more surprising. Indeed, Vietnam's decision to administer and tolerate religious practice through state-sponsored churches is curious given the MarxistLeninist ideological orientation of the regime itself. The Polish case is also fascinating, given that other Catholic and Orthodox domestic churches behind the Iron Curtain were subject to intense coercion during the Soviet era.

Thailand has oscillated between military and civilian rule, though at no time transitioning to a fully consolidated democracy. In terms of religion, Thai regimes have cultivated close relations with conservative Theravada monks and monasteries. From the 1950 's- 1970 's, this strategy was employed in the interest of containing the spread of Marxist ideology from neighboring Cambodia and Laos (Ford 2017). In later decades, authoritarian regimes (military and civilian) often couched their legitimacy in an appeal to tradition, forged through close ties to the monarchy and sangha. In Thailand, a centralized bureaucratic/administrative state predates World War II, and was enhanced by foreign aid and technocratic support during the Cold War era. Though occasionally wielding the coercive arm of the state against dissident monks, the overall trajectory of the relationship between Thai regimes and the sangha has been symbiotic, as regimes have provided generous financial assistance to organized Buddhism, while support from the sangha cloaked regimes in a shroud of legitimacy. 
Though different in terms of religious practice and colonial experience, Malaysia's strategies toward organized religion have closely resembled Thailand's. During the $19^{\text {th }}$ and early $20^{\text {th }}$ century, Britain constructed a centralized bureaucratic/administrative state, by which Malay governing elites built upon after independence. Repressive anti-communist purges during the 1950's and 1960's enhanced coercive capacity to the degree that, thereafter, domestic challenges to the UMNO regime came mostly from other governing elites within the system. As in Thailand, successive Malay regime elites have made a concerted effort to patronize a specific type of religious practice As the government tendency in Thailand has been to sponsor a traditional, conservative form of Buddhism, the corresponding goal in Malaysia has been to promote a moderate version of Sunni Islam through direct financial assistance to Mosques and schools. Meanwhile, Thai and Malay regimes have applied coercion selectively against smaller bases of religious opposition; dissident "left-wing" monks, and Islamist parties, respectively.

Authoritarian regimes embedded in the strong states of Vietnam and Poland, as mentioned previously, share a fascinating history with respect to their relationship with religious organizations. Though both Marxist in ideology and governance, neither regime embarked on heavily coercive policies against religion. Instead, Vietnam, has sanctioned religion through official churches, while Poland during the Cold War failed to tame a powerful Catholic Church. In both cases, historical case-study analysis reveals that respective regimes made a strategic decision to limit their attacks on religious organizations. In Vietnam, the Viet Minh were more concerned with recruiting Vietnamese to fight French and American troops. In turn, embarking on any effort to 
eliminate Buddhism, Catholicism, or the Sects would have undermined popular support. Similarly, in Poland, the Soviet Union recognized as early as the late 1940's, that the relationship between Polish citizens and the Catholic Church could not be destroyed without inciting rebellion. Instead of crushing religious-based resistance, both regimes sought to co-opt religion through the creation of new regime-friendly organizations. While alternative Catholic organizations failed to gain traction in Poland, stateadministered religion in Vietnam has curtailed- though not eliminated- religion-based resistance to the regime.

Authoritarian regimes in low bureaucratic/administrative and low coercive capacity states have experimented extensively with both cooptation and coercion in the hopes of eliminating religiously-based challenges to the regime. In Burma, Laos, Nicaragua, and DR Congo long historical patterns of weak state development, attributable to both extractive colonial regimes and the predatory behavior of postindependence governing elites, has shaped their overall approach to religious organizations.

In Burma and Laos, successive regimes embarked on policies of both cooptation and coercion over the course of several decades. The U Nu (1948-1962) era in Burma and the late LPDR period in Laos (1980-present) is emblematic of regime-sponsored cooptation, while the Ne Win (1962-1988) and early Pathet Lao era (1975-1980), features clear policies of coercion against religious organizations. In Nicaragua and Congo, personalistic rule under Somoza and Mobutu was characterized by successful cooptation of the Catholic hierarchy in those countries (until the 1970's) in the first case, and 
multiple failed attempts to bring the Catholic Church under control in the second.

Patterns of cooptation and coercion in persist in these cases. In contemporary Nicaragua and DR Congo, high-profile conflicts with the Catholic Church serve as a reminder of the Church's relative independence from the respective domestic regimes.

In rare cases, authoritarian regimes operate in states with weak bureaucratic/administrative apparatuses, but strong reserves of coercive power. In Cambodia (1954-present) and South Vietnam (1954-1975), widespread violence against religious organizations was as a preferred strategy for regime elites. In terms of state capacity, each country emerged from French colonization with different degrees of bureaucratic/administrative centralization. While South Vietnam was less developed than the north, it still features the basic components of a "modern" state bureaucracy. The same cannot be said for Cambodia, as the French, viewing it as little more than a strategic outpost, invested far fewer resources in state development.

During the 1950's and 1960's, both Cambodia and South Vietnam beefed up their militaries through cooperation with foreign powers. In Cambodia, Prince Sihanouk played rival Cold War powers off one another, attracting the support of the U.S, the Soviet Union, and eventually China. Meanwhile, the Diem regime in South Vietnam was almost entirely dependent on U.S. military support. Most of these resources went into modernizing the military; regime elites in both states invested little in their civilian bureaucracies.

Violence toward Buddhists in Cambodia spans the decades, with the most extreme repression taking place during the Khmer Rouge era (1975-1979). In South 
Vietnam, Diem's violent crackdowns against Buddhists and the Sects nearly brought down his regime on two separate occasions. In each case, regimes relied upon the resources that they had at their disposal to counter both symbolic and material threats to survival. While the Sihanouk (1954-1970), and Hun Sen (1984-present) regimes in Cambodia did experiment with limited cooptation, they frequently used violence to target religious organizations. Under Vietnamese occupation (1980-1989), coercion was employed extensively against "uncooperative" religious figures. In South Vietnam, the Diem regime never seriously attempted to co-opt Buddhists and minority sects; instead deliberately excluding these groups' leaders from elite-level politics.

The noted differences which have emerged through cross-regional comparison merits further discussion. Specifically, there is some interesting variation between regime management of religion in the majority Catholic countries, as opposed to their Buddhist counterparts. Here, the most obvious takeaway is that in the DR Congo, Poland, and Nicaragua, the institutional strength of the Church, with its international support, presents different challenges for authoritarian regimes. Thus, more research should be conducted on how the internationalization of domestic religion shapes relevant authoritarian strategies. In this context, while regimes do not hesitate to pursue policies of coercion and cooptation, they do so with the understanding that clergy does not simply answer to domestic authorities. A second set of divergences emerge in Southeast Asia through the presence of strong authoritarian parties. In Malaysia and Vietnam, regimes with strong parties have been able to co-opt organized religion. Thus, more research should be conducted on the independent role of party systems as a variable explaining a regime's tendency to engage in policies of cooptation. Specifically, how do parties utilize their 
organizational resources to recruit like-minded religious figures, or alternately, punish dissidents?

While this dissertation fully limits the number of cases analyzed to permit for a more detailed comparison of cases, the universe of cases could be expanded to study authoritarian strategies toward religion in any state with symbolically important and politically active religious groups. While a large-n study of this phenomenon would have to sacrifice contextualization for generalization, a broader analysis of the top-down relationship between state capacity, regime strategy and religious organizations would be extremely valuable.

This research deliberately focuses on the top-down dynamics of the interactions between three important entities, future research could also approach this question from another perspective, examining how religious organizations engage in survival strategies designed to ensure their political influence under authoritarianism. Whether filling social service responsibilities in weak bureaucratic states or participating in protest movements or organized anti-regime violence, this study would provide a complementary account of the relationship among the state, regimes, and religious organizations.

The overall contribution of this dissertation lies in its novel exploration of the complex relationship between states, authoritarian regimes, and religious organizations. While each of these entities has been studied extensively in isolation, this comparative study of the interaction between these variables unveils some important insights. First, authoritarian regimes, particularly in the developing world are forced to grapple with symbolically-powerful religious organizations as potential threats to their survival. 
Secondly, variations in regime strategies toward these organizations is not solely a product of regime ideology or the personality characteristics of individual leaders. This dissertation reveals some interesting similarities and differences in regime strategy across varied types of authoritarian regimes (militarist, Marxist-Leninist, personalist). Most importantly, this research supports the proposition that not all authoritarian regimes are created equal with respect to their access to state resources (Slater and Fenner 2011).

As the preceding case studies reveal, regimes embedded in strong bureaucratic/administrative and coercive states do not need to rely as heavily on the coercive arm of the state as their counterparts in low capacity states. This distinction is more than academic, as authoritarian regimes that forge a close connection to religious organizations do not need to engage in domestically and internationally unpopular crackdowns against dissident religious figures, thus putting the regime on more secure footing. In an era of authoritarian backsliding across much of the developing world, these findings highlight the degree to which patterns of authoritarian governance are powerfully shaped by state resource endowment.

This dissertation also makes new contributions as an exercise in mid-level theory building. Through the creation of a new typology, which clearly links variables at different levels of abstraction, this research problematizes the relationship between states, regimes, and religious organizations deductively. Methodologically, this approach has generated a series of generalizable propositions and findings that reach beyond the study of state-society relations in Southeast Asia. 


\section{LIST OF REFERENCES}

“Communication Fact Book: Cambodia”. Philip D. Sprouse Papers. Hoover Institution Archives: San Francisco: CA.

Abuza, Zachary. 2001. Renovating Politics in Contemporary Vietnam. Boulder: Lynne Rienner Press.

Acemoglu, Daron, and James A. Robinson. 2000. "Why did the West Extend the Franchise? Democracy, Inequality, and Growth in Historical Perspective". The Quarterly Journal of Economics 115:(4). 1167-1199

Acemoglu, Daron. and Robinson. 2012. Why Nations Fail: The Origins of Power, Prosperity and Poverty. NY: Crown Publishers.

Acemoglu, Daron., Ticchi, D., \& Vindigni, A. 2011. "Emergence and Persistence of Inefficient States.” Journal of the European Economic Association, 9(2): 177-208

Alagappa, Muthiah. 2004. Civil Society and Political Change in Asia: Expanding and Contracting Democratic Space. Stanford: Stanford University Press.

Andersen, David., Møller, J., \& Skaaning, S. E. 2014. "The State-Democracy Nexus: Conceptual Distinctions, Theoretical perspectives, and Comparative Approaches". Democratization, 21(7): 1203-1220.

Ardant, Gabriel. and Charles Tilly. 1975. The Formation of National States in Western Europe. Princeton, NJ: Princeton University Press.

Association of Religious Data Archives. 2017. "National Profiles". http://www.thearda.com/internationalData/ (2/6/2018)

Aung Thwin, Michael. 1985. "The British "Pacification "of Burma: Order Without Meaning”. Journal of Southeast Asian Studies 16 (2): 245-261. 
Aung-Thwin, Maureen and Thant Myint-U. 1992. "The Burmese Ways to Socialism" Third World Quarterly 13(1): 67-75.

Bäck, Hanna., \& Hadenius, A. 2008. "Democracy and State Capacity: Exploring a Jshaped Relationship". Governance, 21(1): 1-24.

Beech, Hannah. 2013. "The Face of Buddhist Terror”. Time Magazine

Beetham, David. 1991. The Legitimation of Power. NJ: Humanities Press International

Beresford, Melanie. 1988. Vietnam: Politics, Economics and Society. London: Pinter Publishers.

Berryman, Phillip. 1994. Stubborn Hope: Religion, Politics, and Revolution in Central America. New York: New Press.

Bertocchi, Graziella, \& Spagat, M. 2001. "The Politics of Co-optation”. Journal of Comparative Economics, 29(4): 591-607.

Boix, Carles and Milan Svolik. 2013. "The Foundations of Limited Authoritarian Government: Institutions, Commitment and Power-Sharing in Dictatorships”. The Journal of Politics 75(2) 300-316.

Bourdieu, Pierre. 1991. Language and Symbolic Power. Cambridge: Harvard University Press

Bradstock, Andrew. 1987. Saints and Sandinistas: The Catholic Church in Nicaragua and its Response to the Revolution. London: Epworth Press.

Brown, Graham K. 2005. "Playing the (non) Ethnic Card: The Electoral System and Ehnic Voting Patterns in Malaysia”. Ethnopolitics, 4(4): 429-445. 
Burma Campaign UK. 2017. "Saffron Revolution in Burma".

http://burmacampaign.org.uk/about-burma/2007-uprising-in-burma_ (August 17, 2017).

Callahan, Mary P. 2003. Making Enemies: War and State Building in Burma. Ithaca: Cornell University Press.

Camroux, David. 1996. "State Responses to Islamic resurgence in Malaysia: Accommodation, Co-option, and Confrontation". Asian Survey, 36(9): 852-868

Cárdenas, Mauricio. 2010. "State Capacity in Latin America". Economía, 10(2):1-45.

Casanova, Jose. 1996. "Global Catholicism and the Politics of Civil Society". Sociological Inquiry 66:3

Chandler, David P. 1991. The Tragedy of Cambodian History: Politics, War, and Revolution Since 1945. New Haven: Yale University Press.

Chandler, David P. 1999. Brother Number One: A Political Biography of Pol Pot. Colorado: Westview Press

Chandran, Rina. 2017. "Risking Banishment, Buddhist Monks Speak Up for Land Rights in Cambodia". Reuters News Service. https://www.reuters.com/article/uscambodia-landrights-religion/risking-banishment-buddhist-monks-speak-up-forland-rights-in-cambodia-idUSKBN1CS1CA. (February 9, 2019)

Chapman, Jessica M. 2012. "Religion, Power, and Legitimacy in Ngo Dinh Diem's Republic of Vietnam" in Religion and the Cold War: A Global Perspective ed. Muehlenbeck. Nashville: Vanderbilt University Press.

Chick, Kristen. 2019. "Fighting Authoritarianism: One Mass at a Time." New Republic https://newrepublic.com/article/152576/fighting-authoritarianism-one-mass-time $(3 / 12 / 19)$ 
Cingolani, Luciana. 2013. The State of State Capacity: A Review of Concepts, Evidence and Measures. UNU Working Paper.

Collins, Randall. 1975. Conflict Sociology. New York: Academic Press.

Connors, Michael K. 2009. "Liberalism, Authoritarianism and the Politics of Decisionism in Thailand". The Pacific Review, 22(3), 355-373.

Cribb, Robert. 2010. "Political Genocides in Postcolonial Southeast Asia" in The Oxford Handbook of Genocide Studies ed. Bloxham and Moses. UK: Oxford University Press.

Crouch, Harold. 1996. Government and Society in Malaysia. Ithaca: Cornell University Press.

De Witte, Ludo. 2001. The Assassination of Lumumba. Verso Publishers

Dell, Melissa, Lane N. and Querubin P. 2015. "State Capacity, Local Governance, and Economic Development in Vietnam". NBER Working Paper: 1-40.

DeRouen, Karl R \& David Sobek 2004. "The Dynamics of Civil War Duration and Outcome". Journal of Peace Research 41(3): 303-320.

Dizolele, Mvemba Phezo. 2010. "The Mirage of Democracy in the DRC." Journal of Democracy 21(3):143-157.

Do, Thein. 1999. "The Quest for Enlightenment and Cultural Identity: Buddhism in Contemporary Vietnam" in Buddhism and Politics in Twentieth-Century Asia ed Harris. London: Continuum.

Dubus, Arnaud. 2017. Buddhism and Politics in Thailand. Bangkok: IRASEC

Easton, David. 1957. "An Approach to the Analysis of Political Systems". World Politics 9(03):383-400. 
Easton, David. 1981. "The Political System Besieged by the State". Political Theory 9(3): 303-325.

Edelman, Murray. 1988. Constructing the Political Spectacle. Chicago: The University of Chicago Press.

Edwards, Bob and Michael Foley. 1998. "Civil Society and Social Capital Beyond Putnam". American Behavioral Scientist 42 (1): 124-139.

Ellis, Stephan and Gerrie Ter Haar. 1998. "Religion and Politics in Sub-Saharan Africa". The Journal of Modern African Studies, 36(2):175-201

Englehart, Neil. 2005. "Is Regime Change Enough for Burma: The Problem of State Capacity." Asian Survey 45:4. 622-644.

Englehart, Neil. A. 2009. "State Capacity, State Failure, and Human Rights". Journal of Peace Research, 46(2): 163-180.

Erickson Nepstad, Sharon. 1996. "Popular Religion, Protest, and Revolt: The Emergence of Political Insurgency in the Nicaraguan and Salvadoran Churches of the 1960's1980's." in Disruptive Religion: The Force of Faith in Social Movements ed Smith. New York: Routledge

Evans Peter B. 1995. Embedded Autonomy: States and Industrial Transformation. Princeton: Princeton University Press.

Evans, Grant. 1998. The Politics of Ritual and Remembrance: Laos Since 1975. Honolulu: University of Hawaii Press.

Evans, Peter B. 2012 Embedded Autonomy: States and Industrial Transformation. NJ: Princeton University Press.

Evans, Peter. B., Rueschemeyer, D., \& Skocpol, T. 1985. Bringing the State Back In. Cambridge University Press. 
Fearon, James. D., \& Laitin, D. D. 2003. "Ethnicity, Insurgency, and Civil War”. American Political Science Review, 97(1):75-90.

Fink, Christina. 2001. Living Silence: Burma Under Military Rule. Zed Books

Finnemore, Martha and Kathryn Sikkink. 1998 "International Norm Dynamics and Political Change” International Organization 52:4 887-917

Fishman, R. M. 1990. "Rethinking State and Regime: Southern Europe's Transition to Democracy". World Politics, 42(3): 422-440.

Fomina, Joanna, and Jacek Kucharczyk. 2016. "Populism and Protest in Poland." Journal of Democracy 27(4): 58-68.

Ford, Eugene. 2017. Cold War Monks: Buddhism and America's Secret Strategy in Southeast Asia. New Haven: Yale University Press.

Foroohar, Manzar. 1989. The Catholic Church and Social Change in Nicaragua. Albany: SUNY Press.

Fortin, Jessica. 2010. "A Tool to Evaluate State Capacity in Post-Communist Countries, 1989-2006". European Journal of Political Research 49(5): 654-686.

Fox, Jonathan and Debra Flores. 2009. "Religions, Constitutions, and States: A CrossNational Study". The Journal of Politics. 71:4

Frasch, Tilman. 2013. "The Relic and the Rule of Righteousness: Reflections on U Nu's Dhammavijaya" in Buddhism, Modernity, and the State in Asia: Forms of Engagement eds. Bridge and Kitiarsa. NY: Palgrave Macmillan.

Gandhi, Jennifer and Adam Przeworski. 2007. "Authoritarian Institutions and the Survival of Autocrats”. Comparative Political Studies, 40(11): 1279-1301. 
Gandhi, Jennifer and Przeworski, A. 2006. "Cooperation, Cooptation, and Rebellion Under Dictatorships. Economics \& Politics, 18(1):1-26.

Garrard, David J. "The Protestant Church in Congo: the Mobutu Years and Their Impact." Journal of Religion in Africa 43 (2): 131-166

Geddes, Barbara. 1994. Politician's Dilemma: Building State Capacity in Latin America. University of California Press.

Gentile, Emile. 2006. Politics as Religion. Princeton: Princeton University Press.

Gerschewski, Johannes. 2013. "The Three Pillars of Stability: Legitimation, Repression, and Co-optation in Autocratic Regimes". Democratization, 20(1):13-38.

Gheddo, Pierro. 1970. The Cross and the Bo-Tree: Catholics and Buddhists in Vietnam. New York: Sheed and Ward.

Gibney, Mark, Linda Cornett, Reed Wood, Peter Haschke, Daniel Arnon, and Attilio Pisanò. 2017. The Political Terror Scale 1976-2017. http://www.politicalterrorscale.org. $(8 / 2 / 18)$

Hamayotsu, Kikue. 2002. "Islam and Nation Building in Southeast Asia: Malaysia and Indonesia in Comparative Perspective". Pacific Affairs 75 (3): 353-375.

Hamayotsu, Kikue. 2008. "Beyond Doctrine and Dogma: Religion and Politics in Southeast Asia" in Southeast Asia in Political Science eds. Kuhonta, Slater and Vu. Stanford: Stanford University Press.

Hamm, Patrick., King, L. P., and Stuckler, D. 2012. "Mass Privatization, State Capacity, and Economic Growth in Post-Communist Countries”. American Sociological Review, 77(2):295-324. 
Hanson, Jonathan K. and Rachel Sigman. 2013. “Leviathan's Latent Dimensions: Measuring State Capacity for Comparative Research.” Working Paper, APSA Annual Meeting 2011.

Harris, Ian, 2005. Cambodian Buddhism. Honolulu: University of Hawaii Press.

Harris, Ian. 1999. "Buddhism in Extremis: The Case of Cambodia" in Buddhism and Politics in Twentieth-Century Asia ed. Harris. London: Continuum.

Harris, Ian. 1999. Buddhism and Politics in Twentieth Century Asia. London: Continuum

Harris, Ian. 2001. "Buddhist Sangha Groupings in Cambodia”. Buddhist Studies Review 18:1 73-105

Hedman, Eva Lotta. 2001.“Contesting State and Civil Society: Southeast Asian Trajectories". Modern Asian Studies 35:4: 921-951

Hegel, G.W [1821] 1991. Elements of the Philosophy of Right. New York: Dover Publications

Hendrix, Cullen. S. 2010. "Measuring State Capacity: Theoretical and Empirical Implications for the Study of Civil Conflict”. Journal of Peace Research, 47(3): 273-285.

Hewison, Kevin. 1997. Political Change in Thailand: Democracy and Participation. New York: Routledge

Hinton, Alexander. 2005. Why Did They Kill? Cambodia in the Shadow of Genocide. California: Berkeley University Press

Hlaing, Kyaw Yin. 2003. "Reconsidering the Failure of the Burma Socialist Programme Party Government to Eradicate Internal Economic Impediments" South East Asia Research 11(1):5-58. 
Hochschild, Adam. 1999. King Leopold's Ghost: A Story of Greed, Terror and Heroism in Colonial Africa. Houghton Mifflin.

Holt, John Clifford. 2009. Spirits of the Place: Buddhism and Lao Political Culture. Honolulu: The University of Hawaii Press.

Howe, Adam E. 2018. "Discourses of Exclusion: The Societal Securitization of Burma's Rohingya (2012-2018)." Journal of Asian Security and International Affairs 5 (3): $245-266$.

Human Rights Watch. “All You Can Do is Pray: Crimes Against Humanity and Ethnic Cleansing of Rohingya Muslims in Burma's Arakan State.” 2013. Human Rights Watch.

Human Rights Watch. 2004. "In the Name of Security: Counterterrorism and Human Rights Abuses Under Malaysia’s Internal Security Act”. Human Rights Watch 16(7).

Huntington, Samuel. 1991. The Third Wave: Democratization in the Late Twentieth Century. Norman: University of Oklahoma Press.

Ibrahim, Azeem. 2016. The Rohingyas: Inside Myanmar's Hidden Genocide. London: Hurst Publishers.

Ishii, Yoneo. 1986. Sangha, State and Society: Thai Buddhism in History. Honolulu: University of Hawaii Press.

Jackson, Peter A. 1997. “Withering Center, Flourishing Margins: Buddhism's Changing Political Roles" in Political Change in Thailand: Democracy and Participation Hewison ed. New York: Routledge

Jackson, Peter. A. 1989. Buddhism, Legitimation, and Conflict: The Political Functions of Urban Thai Buddhism. Institute of Southeast Asian Studies. 
Jerryson, Michael K. 2011. Buddhist Fury: Religion and Violence in Southern Thailand. UK: Oxford University Press.

Jordt, Ingrid 2007. Burma's Mass Lay Meditation Movement: Buddhism and the Cultural Construction of Power. Athens: Ohio University Press.

Kauffman, Daniel and Art Kraay. 2017. "The Worldwide Governance Indicators". The World Bank Group.

Kawanami, Hiroko. 2013. Renunciation and Empowerment of Buddhist Nuns in Myanmar-Burma: Building a Community of Female Faithful. Leiden: Brill Press

Kemp-Welch, Arthur. 2008. Poland under Communism: A Cold War History. UK: Cambridge University Press.

Kent, Alexandra. 2006. "Reconfiguring Security: Buddhism and Moral Legitimacy in Cambodia". Security Dialogue 37(3): 343-361

Keyes, Charles. F. 1971. "Buddhism and National Integration in Thailand". The Journal of Asian Studies, 30(3):551-567.

Keyes, Charles. F. 1992. Buddhist Politics and Their Revolutionary Origins in Thailand. Berlin: de Gruyter.

Keyes, Charles. F. 1999. "Buddhism Fragmented: Thai Buddhism and Political Order Since the 1970s." in Keynote address presented at Seventh International Thai Studies Conference, Amsterdam

Keyes, Charles. F. 2013. "Buddhists Confront the State" in Buddhism, Modernity, and the State in Asia eds. Kitiarsa and Whalen-Bridge. NY: Palgrave Macmillan.

Khatib, Line. 2013. "Syria's Civil Society as a Tool for Regime Legitimacy", in Civil Society in Syria and Iran: Activism in Authoritarian Contexts eds. Aarts \& Cavatorta. Boulder: Lynne Rienner. 
Kiernan, Ben. 1981. "Origins of Khmer Communism” Southeast Asian Affairs 8:161-180.

Kiernan, Ben. 1985. How Pol Pot Came to Power: Colonialism, Nationalism, and Communism in Cambodia 1930-1975. London: Verso

Kiernan, Ben. 1996. The Pol Pot Regime: Race, Power, and Genocide in Cambodia under the Khmer Rouge (1975-1979). Connecticut: Yale University Press.

Kingsbury, Damien. 2005. South-East Asia: A Political Profile. $2^{\text {nd }}$ Edition. UK: Oxford University Press.

Kinne, Brandon. 2005. "Decision Making in Autocratic Regimes: A Poliheuristic Perspective.” International Studies Perspectives. (6) 114-128

Kisangani, Emizet F. and Jeffrey Pickering. 2014. "Rebels, Rivals, and Post-Colonial State-Building: Identifying Bellicist Influences on State Extractive Capacity International Studies Quarterly 58: 187-198

Kiser, Edgar. 2001. "Determinants of the Growth of the State: War and Taxation in Early Modern France and England”. Social Forces 80 (2): 411-488.

Knutsen, C. H. (2012). "Democracy, dictatorship and technological change”. Governance and knowledge. The politics of foreign investment, technology and ideas, 13-28.

Knutsen, Carl Henrik. 2013. "Democracy, State Capacity, and Economic Growth." World Development 43:1-18.

Lacayo, Javier Arguello and Daniel Lansberg-Rodriguez. 2018. "How a Nicaragua Priest Made a Deal with the Devil". Foreign Policy. https://foreignpolicy.com/2018/08/03/nicaraguas-catholic-church-made-a-dealwith-the-devil/ $(5 / 4 / 2019)$

Lee, Raymond M. and Susan E. Ackerman. 1997. Sacred Tensions: Modernity and Religious Transformation in Malaysia. Columbia: University of South Carolina Press. 
Lee, Terence. 2014. Defect or Defend: Military Responses to Popular Protests in Authoritarian Asia. Baltimore: JHU Press.

Levitsky, Steven and Lucan A. Way. 2001. Competitive Authoritarianism: Hybrid Regimes After the Cold War. UK: Cambridge University Press

Lintner, Bertil. 2009. The Resistance of the Monks: Buddhism and Activism in Burma. Human Rights Watch.

Linz, Juan and Alfred Stepan. 1996. Problems of Democratic Transition and Consolidation: Southern Europe, South America, and Post-Communist Europe. Baltimore: Johns Hopkins University Press.

Liow, Joseph Chinyong. 2009. Piety and Politics: Islamism in Contemporary Malaysia. UK: Oxford University Press.

Longman, Timothy P. 1998. "Empowering the weak and protecting the powerful: The contradictory nature of churches in Central Africa." African Studies Review 41(1): 49-72.

Malkin, Elisabeth and Frances Robles. 2018. "Nicaragua Clergy, Siding with Protestors Becomes 'Terrible Enemy' of Ortega”. New York Times 22 July 2018

Mann, Michael 1986. The Sources of Social Power. UK: Cambridge University Press.

Mann, Michael. 1984. "The Autonomous Power of the State: Its Origins, Mechanisms and Results.” European Journal of Sociology 25(02):185-213.

Martinez, Patricia. A. 2001. "The Islamic State or the State of Islam in Malaysia". Contemporary Southeast Asia, 474-503.

Matthews, Bruce. 1992. "The Place of Religion in Vietnam Today". Buddhist-Christian Studies 12: 65-74. 
Matthews, Bruce. 1993. "Buddhism Under a Military Regime: The Iron Heel in Burma”. Asian Survey 33 (4): 408-423.

Matthews, Bruce. 1997. "The Present Fortune of Tradition-Bound Authoritarianism in Myanmar". Pacific Affairs 71(1): 7-23.

Matthews, Bruce. 1999. "The Legacy of Tradition and Authority: Buddhism and the Nation in Myanmar" in Buddhism and Politics in Twentieth-Century Asia ed. Ian Harris. London: Continuum.

McCargo, Duncan 2009. "Thai Buddhism, Thai Buddhists and the Southern Conflict". Journal of Southeast Asian Studies 40 (1): 1-10

McCargo, Duncan. 2004. "Buddhism, Democracy and Identity in Thailand". Democratization, 11(4): 155-170.

McCargo, Duncan. 2005. "Network Monarchy and Legitimacy Crises in Thailand". The Pacific Review, 18(4): 499-519.

McCarthy, Stephen. 2008. "Overturning the Alms Bowl: The Price of Survival and the Consequences for Political Legitimacy in Burma”. Australian Journal of International Affairs 62(3) 298-314.

McCarthy, Stephen. 2010. "From Coup d'état to 'Disciplined Democracy' The Burmese Regime's Claim to Legitimacy” Regional Outlook Paper Number 23: Griffith Asia Institute 1-30.

Means, Gordon P. 1996. "Soft Authoritarianism in Malaysia and Singapore” Journal of Democracy (4): 103-117.

Mendelson, E. Michael. 1975. Sangha and State in Burma: A Study of Monastic Sectarianism and Leadership. Ithaca: Cornell University Press

Miliband, Ralph. 1969. The State in Capitalist Society. New York: Basic Books 
Mohamad, Maznah. 2010. "Making Majority, Undoing Family: Law, Religion and the Islamization of the State in Malaysia”. Economy and Society, 39(3): 360-384.

Mohamad, Maznah. 2010. "The Ascendance of Bureaucratic Islam and the Secularization of the Sharia in Malaysia”. Pacific Affairs, 83(3): 505-524.

Monticone, Ronald C. 1986. The Catholic Church in Communist Poland 1945-1985:

Forty Years of Church-State Relations. New York: Columbia University Press.

Murat, Leznek. 2012. "Service with Body and Soul: The Institutionalized Atheism of the Security Service Officers in Communist Poland 1944-1989” in Religion and the Cold War: A Global Perspective ed. Muehlenbeck. Nashville: Vanderbilt University Press.

Murdoch, J. B. 1967. The 1901-1902” Holy Man's” Rebellion. Sciences 5: 78-86.

Myoe, Maung Aung. 2009. Building the Tatmadaw: Myanmar Armed Forces Since 1948. Singapore: Institute of Southeast Asian Studies.

Offe, Claus.1972. Advanced Capitalism and the Welfare State. Politics \& Society, 2(4): 479-488.

Osborne, Milton. 2013. Southeast Asia: An Introductory History. $11^{\text {th }}$ Edition. Australia: Allyn \& Unwin.

Owen, Norman G. 2005. The Emergence of Modern Southeast Asia. Honolulu: The University of Hawaii Press.

Oxford Burma Alliance. 2017. "The Ne Win Years: 1962-1988”. http://www.oxfordburmaalliance.org/1962-coup--ne-win-regime.html (2/10/2017)

Pettit, Alphonsus. 2018. "New Hun Sen Threats as Sham Election Nears". The Diplomat. https://thediplomat.com/2018/02/new-hun-sen-threats-as-cambodias-shamelection-nears/ (10/2/19) 
Pew Research Center. 2016. "Trends in the Global Restrictions on Religion"

Pholsena, Vatthana. 2006. Post-War Laos: The Politics of Culture, History, and Identity. Ithaca: Cornell University Press.

Phongpaichit, Pasuk and Chris Baker. 2002. Thailand: Economy and Politics. UK: Oxford University Press.

Pierson, Harry H. 1968. "Buddhism and the Buddhist Programming of the Asia Foundation in Asia" (Box 2). Hoover Institution Archives: San Francisco, CA.

Poulantzas, Nicos. 1974. "Internationalisation of Capitalist Relations and the NationState". Economy and Society 3(2): 145-179.

Riggs, Fred. W. 1966. Thailand: The Modernization of a Bureaucratic polity. Honolulu, East-West Center Press.

Schatzberg, Michael G. 1997. "Beyond Mobutu: Kabila and the Congo." Journal of Democracy 8(4): 70-84.

Schedler, Andreas. 2002. "The Menu of Manipulation". Journal of Democracy, 13(2): 36-50.

Schmitter, Phillipe. C. 1985. "Neo-corporatism and the State" in Grant ed. Political Economy of Corporatism. Macmillan Education UK.

Schober, Juliane. 1995. "The Theravada Buddhist Engagement with Modernity in Southeast Asia: Whither the Social Paradigm of the Galactic Polity?" Journal of Southeast Asian Studies 26 (2): 307-325.

Schober, Juliane. 1997. "Buddhist Just Rule and Burmese National Culture: State Patronage of the Chinese Tooth Relic in Myanmar". History of Religions 36(3): 218-243. 
Schober, Juliane. 2005. "Buddhist Visions of Moral Authority and Modernity in Burma" in Burma at the Turn of the Twenty-First Century ed. Skidmore. Honolulu: University of Hawaii Press.

Scott, J. C. 2009. The Art of Not Being Governed: An Anarchist History of Upland Southeast Asia. Yale University Press.

Seabrooke, Leonard. 2002. "Bringing Legitimacy Back in to Neo-Weberian State Theory and International Relations." Working Paper: Australian National University

Sebald, William J. 1952. "William J. Sebald Diaries 1952-1954 (Folder 1). Hoover Institution Archives: San Francisco, CA

Selth, Andrew. 1996. Transforming the Tatmadaw: The Burmese Armed Forces Since 1988. Canberra: Australian National University

Silverstein, Josef. 1980. Burmese Politics: The Dilemma of National Unity. NJ: Rutgers University Press.

Skocpol, Theda. 1979. States and Social Revolutions: A Comparative Analysis of France, Russia, and China. UK: Cambridge University Press.

Skocpol, Theda. Evans and Rueschmeyer. 1985 Bringing the State Back In. Cambridge: Cambridge University Press

Slater, Dan and Sofia Fenner. 2011. "State Power and Staying Power: Infrastructural Mechanisms and Authoritarian Durability". Journal of International Affairs 15-29

Slater, Dan. 2003. "Iron Cage in an Iron Fist: Authoritarian Institutions and the Personalization of Power in Malaysia." Comparative Politics 36 (1): 81-101.

Slater, Dan. 2010. Ordering Power: Contentious Politics and Authoritarian Leviathans in Southeast Asia. UK: Cambridge University Press. 
Slater, Dan. 2012. "Strong-State Democratization in Malaysia and Singapore". Journal of Democracy, 23(2): 19-33.

Soifer, Hillel and Vom Hau, M. 2008. "Unpacking the Strength of the State: The Utility of State Infrastructural Power." Studies in Comparative International Development 43(3-4):219-230.

Spencer, Robert F. 1954. "Report of Observations Made at the Gatherings of the Sixth Great Buddhist Council (Rangoon May 1954-May 1956); Second Session (November 1954) and at the Third Biennial Conference of the World Fellowship of Buddhists (Rangoon, December $\left.3^{\text {rd }}-6^{\text {th }} 1954\right)$, (Folder P-131). Hoover Institution Archives: San Francisco; CA.

Steinberg, David. 1997. "A Void in Myanmar: Civil Society in Burma”. BCN.

Stuart-Fox, Martin. 1983. "Marxism and Theravada Buddhism: The Legitimation of Political Authority in Laos". Pacific Affairs 56 (3): 428-454.

Stuart-Fox, Martin. 1999. "Laos: From Buddhist Kingdom to Marxist State" in Buddhism and Politics in Twentieth-Century Asia ed Harris. London: Continuum.

Stubbs, Richard. 1999. "War and Economic Development: Export-oriented Industrialization in East and Southeast Asia. Comparative Politics 31 (3): 337.

Styllis, George and Patthiya Tongfueng. 2017. “A Temple Under Siege: Wat Phra Dhammakaya". The Diplomat. https://thediplomat.com/2017/03/a-temple-undersiege-wat-phra-dhammakaya/_23 March 2017

Suksamran, Somboon. 1982. Buddhism and Politics in Thailand: A Study of SocioPolitical Change and Political Activism of the Thai Sangha. Singapore: ISEAS

Sullivan, Michael. 2016. Cambodia Votes: Democracy, Authority, and International Support for Elections 1993-2013. Copenhagen: NIAS Press. 
Svolik, Milan. W. 2012. The Politics of Authoritarian Rule. Cambridge University Press.

Swearer, Donald. K. 1999. "Centre and Periphery: Buddhism and Politics in Modern Thailand". Harris ed. Buddhism and Politics in Twentieth-Century Asia.

Tambiah, Stanley. 1976. World Conqueror and World Renouncer: A Study in Buddhism and Polity in Thailand Against a Historical Background. UK: Cambridge University Press

Tarling, Nicholas. 1999. The Cambridge History of Southeast Asia: Volume Two: Part One from 1800 to the 1930's. UK: Cambridge University Press.

Tarling, Nicholas. 1999. The Cambridge History of Southeast Asia: Volume Two: Part Two from World War II to the Present. UK: Cambridge University Press.

Taylor, Philip. 2004. Goddess on the Rise: Pilgrimage and Popular Religion in Vietnam. Honolulu: University of Hawaii Press.

Taylor, Robert H. 2009. The State in Myanmar. Honolulu: University of Hawaii Press

Than, Tin M.M. 1988. "The "Sangha" and "Sasana" in Socialist Burma". Sojourn: Journal of Social Issues in Southeast Asia, 3(1): 26-61.

The Irrawaddy. 2018. "Thailand Arrests Senior Monks in Temple Raids to Clean up Buddhism." https://www.irrawaddy.com/news/thailand-arrests-senior-monkstemple-raids-clean-buddhism.html_(25 May 2018)

Thies, Cameron G. 2010. "Of Rulers, Rebels and Revenue: State capacity, Civil War Onset and Primary Commodities". Journal of Peace Research 47(3): 321-332

Topmiller, Robert. 2000. "Vietnamese Buddhism in the 1990's". Cross Currents 232240. 
Tun, Sai Khaing Myo. 2011. “A Comparative Study of State-Led Development in Myanmar (1988-2010) and Suharto's Indonesia: An Approach from the Developmental State Theory". Journal of Current Southeast Asian Affairs 30(1): 69-94.

U.S. Department of State. 2015. Country Profiles: Cambodia and Vietnam. https://www.state.gov/j/drl/irf/rpt/\# (5/6/16)

Vanthemsche, Guy. 2012. Belgium and the Congo, 1885-1980. UK: Cambridge University Press

Vasavakul, Thaveeporn. 1995. "Vietnam: The Changing Models of Legitimation "in Political Legitimacy in Southeast Asia: The Quest for Moral Authority ed. Alagappa. Palo Alto: Stanford University Press.

Verma, Vidhu. 2002. Malaysia: State and Civil Society in Transition. Boulder: Lynne Rienner Publishers.

Vu, Tuong. 2014. "Persistence amid Decay: The Communist Party of Vietnam at 83" in Politics in Contemporary Vietnam: Party, State, and Authority Relations ed. London. UK: Palgrave Macmillan.

Walton, Mathew. 2017. Buddhism, Politics, and Political Thought in Myanmar. UK: Cambridge University Press.

Walton, Matthew and Michael Jerryson. 2016. "The Authorization of Religio-Political Discourse: Monks and Buddhism in Contemporary Myanmar and Beyond." Politics and Religion 9(4): 794-814

Walton, Matthew. 2015. "Monks in Politics, Monks in the World: Buddhist Activism in Contemporary Myanmar." Social Research: An International Quarterly. 82(2): $507-530$ 
Warner, Denis. 1966. "Vietnam Why: A Collection of Reports and Comments from the Reporter." Victoria Shuck Papers, Box 2: Folder 3. Hoover Institution Archives: San Francisco: CA.

Weber, Max (2004) \{1919\}) "Politics as a Vocation" in the Vocation Lectures, Owen and Strong eds. Hackett Publishing

Weber, Max (2014, \{1958\}) The Three Pure Types of Legitimate Rule in The Essential Weber: A Reader. Whimster, Sam Ed. UK: Routledge.

Weichong, Ong. 2014. Malaysia's Defeat of Armed Communism: The Second Emergency, 1968-1989 (Vol. 102).UK: Routledge.

Weisbord, Robert G. 2003. "The King, the Cardinal and the Pope: Leopold II's Genocide in the Congo and the Vatican." Journal of Genocide Research 5(1):35-45.

Whetho, Ayo, and Ufo Okeke Uzodike. 2008. "Religious Networks in Post-Conflict Democratic Republic of the Congo: A Prognosis." African Journal on Conflict Resolution 8 (3): 57-84.

Williams, Phillip J. 1989. The Catholic Church and Politics in Nicaragua and Costa Rica. Pittsburgh: University of Pittsburgh Press.

Wintrobe, Ronald. 1990. "The Tinpot and the Totalitarian: An Economic Theory of Dictatorship". American Political Science Review, 84 (03): 849-872.

Wintrobe, Ronald. 1998. The Political Economy of Dictatorship, UK: Cambridge University Press

Wintrobe. Ronald. 2007. "Dictatorship: Analytical Approaches" in The Oxford Handbook of Comparative Politics eds. Boix, and Stokes. UK: Oxford University Press.

World Bank Group. 2016. "Armed Forces Personnel, Total” https://data.worldbank.org/indicator/ms.mil.totl.p1 (6/1/2016) 
World Bank Group. 2016. "Military Expenditure (\% of GDP)." https://data.worldbank.org/indicator/MS.MIL.XPND.GD.ZS?view=chart $(6 / 1 / 2016)$

Wyatt, David K. 2003. Thailand: A Short History. New Haven: Yale University Press

Young, Iris. 2000. Inclusion and Democracy. Oxford: Oxford University Press. 
VITA

\section{ADAM E. HOWE}

Born, Port Jefferson, NY

2006

2011

2016

2013-Present

2014

$2017-18$

$2017-18$

2019
B.A. Wheeling Jesuit University Wheeling, WV M.A. Duquesne University Pittsburgh, PA

M.A. Florida International University

Miami, FL

$\mathrm{PhD}$ Candidate. Florida International University Best Teaching Assistant in Political Science Florida International University Silas Palmer Research Fellowship Stanford University Morris and Anita Broad Research Fellowship Florida International University Dissertation Year Fellowship Florida International University

\section{PUBLICATIONS}

"A Long Way to Peace: Identities, Genocide, and State Preservation in Burma (1948-2018)" w/ Zachary A. Karazsia in Politics, Groups, and Identities (Fall 2018)

"Discourses of Exclusion: The Societal Securitization of Burma's Rohingya (2012-2018)" in Journal of Asian Security and International Affairs 5:3 1-22. (Fall 2018)

"Liberia and Sierra Leone: Sustainable Paths to Development?"

Interdisciplinary Journal of Conflict Science 1:1 30-45. (Summer 2015) 